April 2002 • NREL/TP-550-30839

\title{
Thermal Performance of Unvented Attics in Hot-Dry Climates
}

Robert Hendron and Ren Anderson

National Renewable Energy Laboratory

Paul Reeves

Partnership for Resource Conservation

Ed Hancock

Mountain Energy Partnership

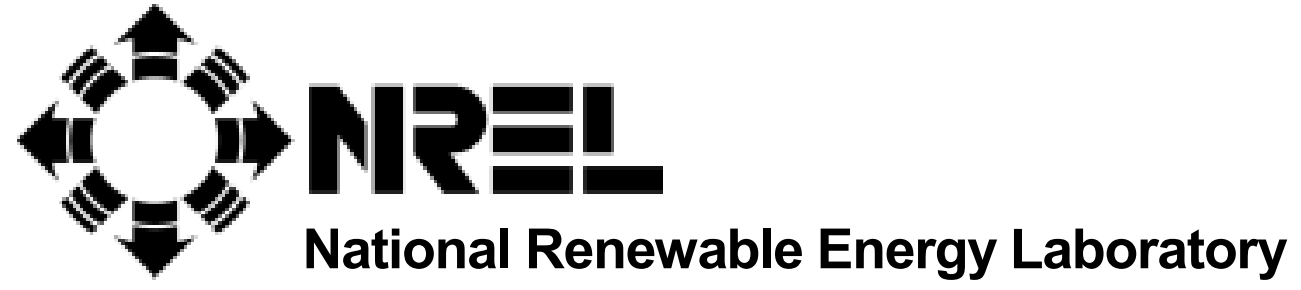

1617 Cole Boulevard

Golden, Colorado 80401-3393

NREL is a U.S. Department of Energy Laboratory

Operated by Midwest Research Institute • Battelle • Bechtel

Contract No. DE-AC36-99-G010337 


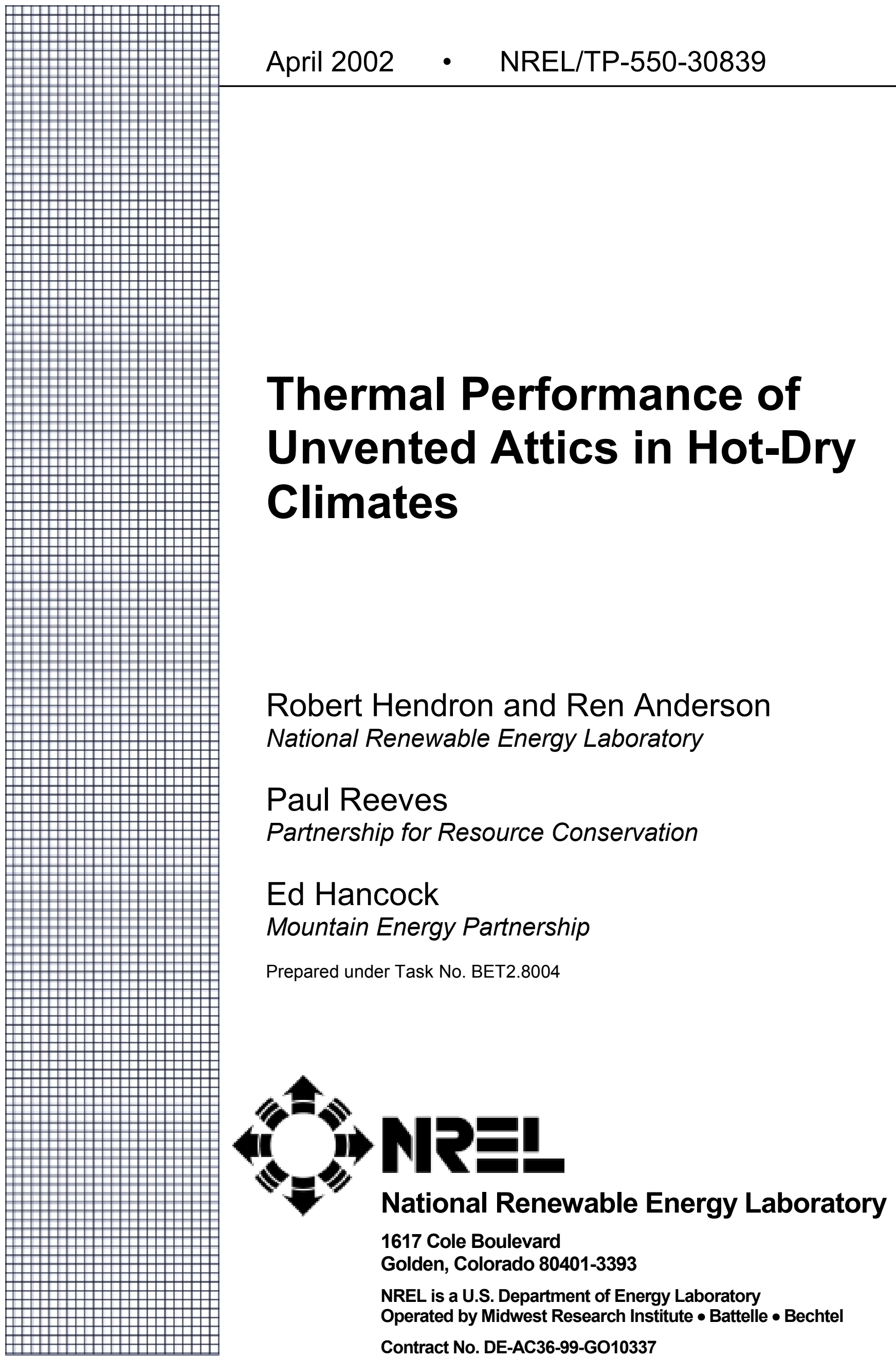




\section{NOTICE}

This report was prepared as an account of work sponsored by an agency of the United States government. Neither the United States government nor any agency thereof, nor any of their employees, makes any warranty, express or implied, or assumes any legal liability or responsibility for the accuracy, completeness, or usefulness of any information, apparatus, product, or process disclosed, or represents that its use would not infringe privately owned rights. Reference herein to any specific commercial product, process, or service by trade name, trademark, manufacturer, or otherwise does not necessarily constitute or imply its endorsement, recommendation, or favoring by the United States government or any agency thereof. The views and opinions of authors expressed herein do not necessarily state or reflect those of the United States government or any agency thereof.

Available electronically at http://www.osti.gov/bridge

Available for a processing fee to U.S. Department of Energy

and its contractors, in paper, from:

U.S. Department of Energy

Office of Scientific and Technical Information

P.O. Box 62

Oak Ridge, TN 37831-0062

phone: 865.576.8401

fax: 865.576 .5728

email: reports@adonis.osti.gov

Available for sale to the public, in paper, from:

U.S. Department of Commerce

National Technical Information Service

5285 Port Royal Road

Springfield, VA 22161

phone: 800.553 .6847

fax: 703.605.6900

email: orders@ntis.fedworld.gov

online ordering: http://www.ntis.gov/ordering.htm 


\section{Executive Summary}

\section{Introduction}

As unvented attics become a more common design feature implemented by Building America partners in hot-dry climates of the United States, more attention has been focused on how this approach affects heating and cooling energy consumption. By eliminating the ridge and eave vents that circulate outside air through the attic in most new houses, and by moving the insulation to the roof plane, an unvented attic becomes a semiconditioned space and creates a more hospitable environment for cooling ducts that may be present. An energy trade-off is made, however, because the additional surface area (and perhaps reduced insulation thickness) increases the building loss coefficient of the house. Other advantages and disadvantages, unrelated to energy, must also be considered. This report addresses only the energy-related effects of unvented attics in hot-dry climates.

\section{Approach}

The National Renewable Energy Laboratory (NREL) has conducted field testing and hourly building simulations for several Building America projects to evaluate energy use in vented and unvented attics in hot-dry climates. The projects yielding the most conclusive results were in Las Vegas, Nevada, and Tucson, Arizona. Testing was conducted under winter and summer conditions in Las Vegas and under summer conditions in Tucson. One Las Vegas prototype house and one nearly identical base-case house (differing only in the attic design) were tested during the summer using holes of different sizes to induce various amounts of duct leakage into each attic. NREL performed comprehensive testing of envelope leakage, duct leakage, temperature distribution, and electricity consumption. Some of the resulting test data were used as inputs to hourly building simulation models. The models were then calibrated with actual electricity measurements and then used to predict seasonal or annual energy consumption under realistic operating conditions.

\section{Results}

In summer, testing of the Las Vegas prototype house demonstrated that the thermal performance of an unvented attic is highly dependent on duct leakage. When the ducts were well sealed, the vented attic and unvented attic showed very little difference in cooling energy. When air leakage was increased to 200 cubic feet per minute ( $\mathrm{cfm}$ ) for both the vented and unvented attic, energy savings up to $11.5 \%$ were observed for the unvented attic. This effect was confirmed using hourly simulations of the two houses. The simulations developed for the Las Vegas project also predicted that the thermal performance of the unvented attic would be highly dependent on the local climatic conditions. A direct comparison of the vented and unvented attics was not possible for the Tucson test, but an energy simulation predicted either a small energy benefit or a small energy loss for the unvented attic, depending on which energy efficiency measures were added to the model first. High sensitivity to attic insulation R-value, roof solar absorptivity, and air infiltration were also predicted for the unvented attic using the Tucson model. 


\section{Acknowledgments}

The authors express their appreciation to George James, U.S. Department of Energy Program Manager for Building America, for his ongoing leadership and support of this research area. We would also like to thank Sara Farrar-Nagy of the National Renewable Energy Laboratory for her efforts in leading the test and analysis activities at NREL when this work was conducted. In addition, we recognize the research and design work performed by the Building Science Consortium and their assistance in the development of this report. 


\section{Table of Contents}

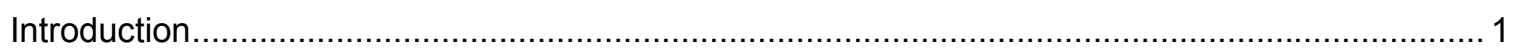

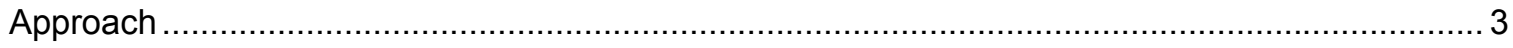

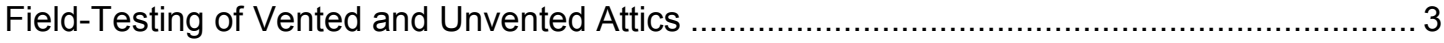

Modeling an Unvented Attic Using DOE-2.2 Results...................................................... 3

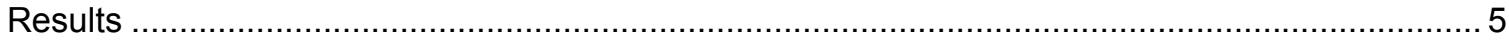

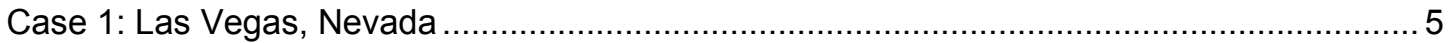

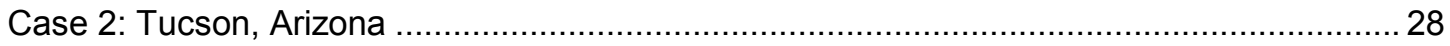

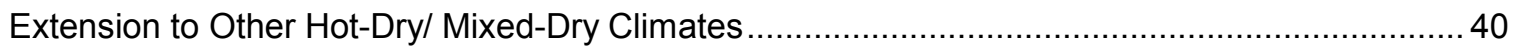

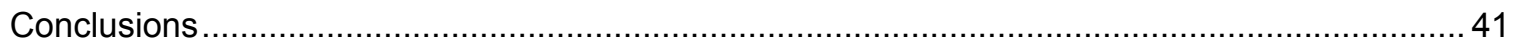

Appendix: Sensitivity Analysis of the Pulte,Tucson, Unvented Attic Prototype ............................ 42

\section{List of Tables}

Table 1. Potential Advantages and Disadvantages of Unvented Attics .................................. 1

Table 2. Las Vegas Test House Descriptions (Winter) ….................................................... 6

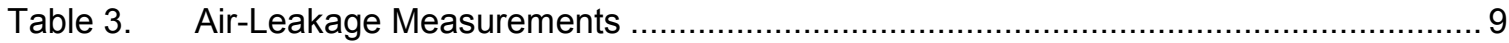

Table 4. Summary of Tracer Gas Test Results during Night Test Periods (11:00 p.m. to 5:00 a.m.) …..................................................... 10

Table 5. Las Vegas Test House Descriptions (Summer) ........................................................ 12

Table 6. Summary of Tracer Gas Test Results during Daytime Test Periods (10:00 a.m. to 4:00 p.m.) ................................................................... 16

Table 7. Daily Electricity Measurements During the Summer Test Period (kWh) .................. 18

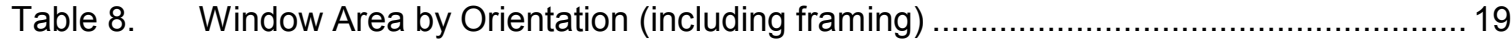

Table 9. Comparison of Average Cooling Energy and Standard Deviation Based on Simulations and Field Measurements …............................................. 25

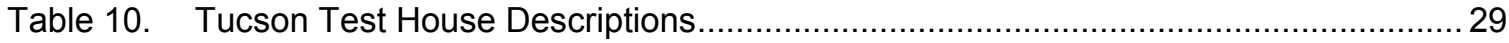

Table 11. Summary of Modeling Results for Pulte, Tucson ................................................... 36

Table 12. Increment 7: Change from Vented to Unvented Attic ............................................. 38

Table A-1. Nominal Values of Parameters Used in the Sensitivity Analysis .............................A-1 


\section{List of Figures}

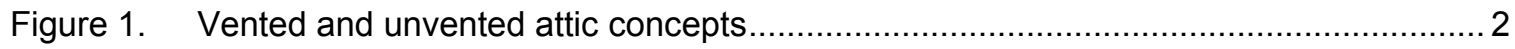

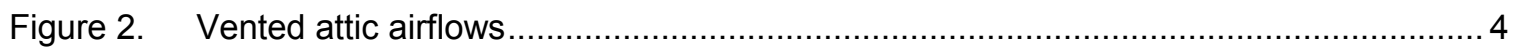

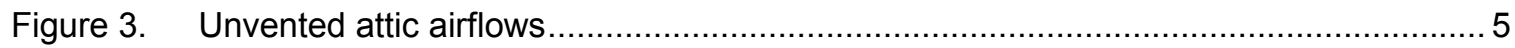

Figure 4. Front and rear views of first Las Vegas prototype house ........................................ 7

Figure 5. Front and rear views of first Las Vegas base-case house...................................... 7

Figure 6. The difference between inside and outside temperatures varied from $10^{\circ}$ to $20^{\circ} \mathrm{C}\left(18^{\circ}\right.$ to $\left.36^{\circ} \mathrm{F}\right)$ during the 9 -day winter test period ..................................... 8

Figure 7. Wind speed reached about $4 \mathrm{~m} / \mathrm{s}(9 \mathrm{mi} / \mathrm{hr})$ late in the 9 -day test period ..................... 8

Figure 8. Air infiltration during periods of co-heating and normal furnace operation as

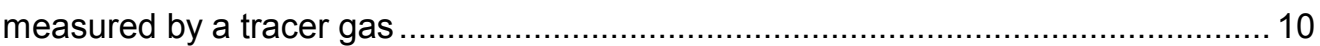

Figure 9. Attic temperatures relative to outside temperatures during test period .................... 11

Figure 10. Front and rear views of second Las Vegas prototype house ..................................... 13

Figure 11. Front view of second Las Vegas base-case house ............................................. 13

Figure 12. Outdoor and indoor temperatures during the summer test period .......................... 14

Figure 13. Solar insolation and wind speed during the summer test period .............................. 15

Figure 14. Air infiltration during the summer test period as measured by a tracer gas .............. 16

Figure 15. Attic temperatures during the summer test period ............................................. 17

Figure 16. Hourly power measurements during the summer test period ................................. 18

Figure 17. Las Vegas base-case house building geometry, view from the southeast................. 20

Figure 18. Building geometry of Las Vegas base-case house, view from the northeast, with shading from adjacent houses

Figure 19. Pretest simulated cooling profile for Las Vegas test house with vented and unvented attics and varying levels of duct leakage. The unvented attic was insulated to R-22 and the vented attic to R-30 .......................................... 23

Figure 20. Monitored versus simulated cooling energy with tight ducts (Case 1)...................... 24

Figure 21. Monitored versus simulated cooling energy with 100-cfm supply duct leakage (Case 2).

Figure 22. Monitored versus simulated cooling energy with 100-cfm supply plus a 100-cfm return duct leakage (Case 3, Thursday-Saturday) and an estimated 200-cfm supply plus a 100-cfm return duct leakage (Case 4, Sunday)

Figure 23. Predicted monthly cooling energy for Las Vegas test house with vented attic insulated to $\mathrm{R}-30$ at the ceiling plane and unvented attic insulated to R-22 at the roof plane..... 26

Figure 24. Annual cooling requirement versus duct leakage for Las Vegas test houses ............ 27

Figure 25. Front and rear views of Tucson prototype house 30

Figure 26. Inside and outside temperatures for Tucson prototype during a 3-day period of normal air conditioner operation. The attic temperature was only monitored for the first day. 


\section{List of Figures (continued)}

Figure 27. Wind speed near Tucson prototype during 3-day period of normal operation

Figure 28. Air-exchange rate for Tucson prototype during 3-day period of normal operation.

Figure 29. Front of prototype house (shading not included)

(Image captured from PowerDOE)

Figure 30. Side and back of prototype house, including porch and nearby shading (Image captured from PowerDOE)

Figure 31. Comparison of cooling energy for vented and unvented attics

in Phoenix, Arizona.

Figure 32. Comparison of cooling energy cost for vented and unvented attics

in Sacramento, California

Figure A-1. Comparison of heating energy for vented and unvented attics, sensitivity to duct leakage.

Figure A-2. Comparison of cooling energy for vented and unvented attics, sensitivity to duct leakage.

Figure A-3. Comparison of total space-conditioning energy for vented and unvented attics, sensitivity to duct leakage.

Figure A-4. Comparison of heating energy for vented and unvented attics, sensitivity to unvented attic air infiltration (Vented attic infiltration is held constant at $1.5 \mathrm{ACH})$

Figure A-5. Comparison of cooling energy for vented and unvented attics, sensitivity to unvented attic air infiltration (Vented attic infiltration is held constant at $1.5 \mathrm{ACH})$.....

Figure A-6. Comparison of total space-conditioning energy for vented and unvented attics, sensitivity to unvented attic air infiltration (Vented attic infiltration is held constant at $1.5 \mathrm{ACH}$ )

Figure A-7. Comparison of heating energy for vented and unvented attics, sensitivity to unvented attic roof R-value (Vented attic $R$-value is held constant at R-30).

Figure A-8. Comparison of cooling energy for vented and unvented attics, sensitivity to unvented attic roof R-value (Vented attic R-value is held constant at R-30).

Figure A-9. Comparison of total space-conditioning energy for vented and unvented attics, sensitivity to unvented attic roof R-value (Vented attic $R$-value is held constant at R-30)

Figure A-10. Comparison of heating energy for vented and unvented attics, sensitivity to roof absorptivity.

Figure A-11. Comparison of cooling energy for vented and unvented attics, sensitivity to roof absorptivity.

Figure A-12. Comparison of space-conditioning energy for vented and unvented attics, sensitivity to roof absorptivity 


\section{Introduction}

Unvented attics have gained a significant amount of attention in the building science community over the past 5 years as a number of builders have eliminated attic vents and moved the insulation layer from the ceiling plane to the roof plane. This creates a semiconditioned space where air ducts can reside in a much milder environment, particularly in hot climates. The purpose of this report is to evaluate the energy impacts of unvented attics from the body of evidence that has accumulated through the research of Building America teams for builders in hot-dry climates, where the most extensive adoption of this technique has occurred. Beyond the energy impacts of unvented attics, many other performance and quality assurance issues must be considered when evaluating this technology. Some of the most important advantages and disadvantages of unvented attics are summarized in Table 1.

Table 1. Potential Advantages and Disadvantages of Unvented Attics

\begin{tabular}{ll}
\hline \multicolumn{1}{c}{ Potential Advantages } & \multicolumn{1}{c}{ Potential Disadvantages } \\
\hline - Milder environment for air ducts & - Larger area for air leakage and heat \\
- Eliminates cost of installing vents & gain/loss \\
- Semiconditioned storage area & - Additional cost for insulation \\
- Smaller latent load on air conditioner & - More difficult to install insulation at roof \\
(humid climates only). & level compared to ceiling plane \\
& - Higher roof sheathing temperature \\
& - Higher shingle/tile temperature \\
& - Gas appliances (e.g., furnace, water \\
& heater) located in attic must be closed- \\
& combustion or be moved to garage. \\
\hline
\end{tabular}

The basic approach to creating an unvented attic, or cathedralized roof, is illustrated in Figure 1. The fiberglass batts, blown-in cellulose, or blown-in fiberglass insulation that typically fills the joist space in a vented attic is replaced with either netted and blown cellulose or fiberglass batts placed between roof trusses or rafters. Eave, ridge, and other roof vents are eliminated. The continuous air barrier is moved to the roof plane instead of the ceiling, requiring careful attention to detail when installing the air barrier around complex roof geometries. Supply and return air ducts remain in the semiconditioned space of the attic, avoiding the severe temperature swings experienced by a traditional vented attic. 


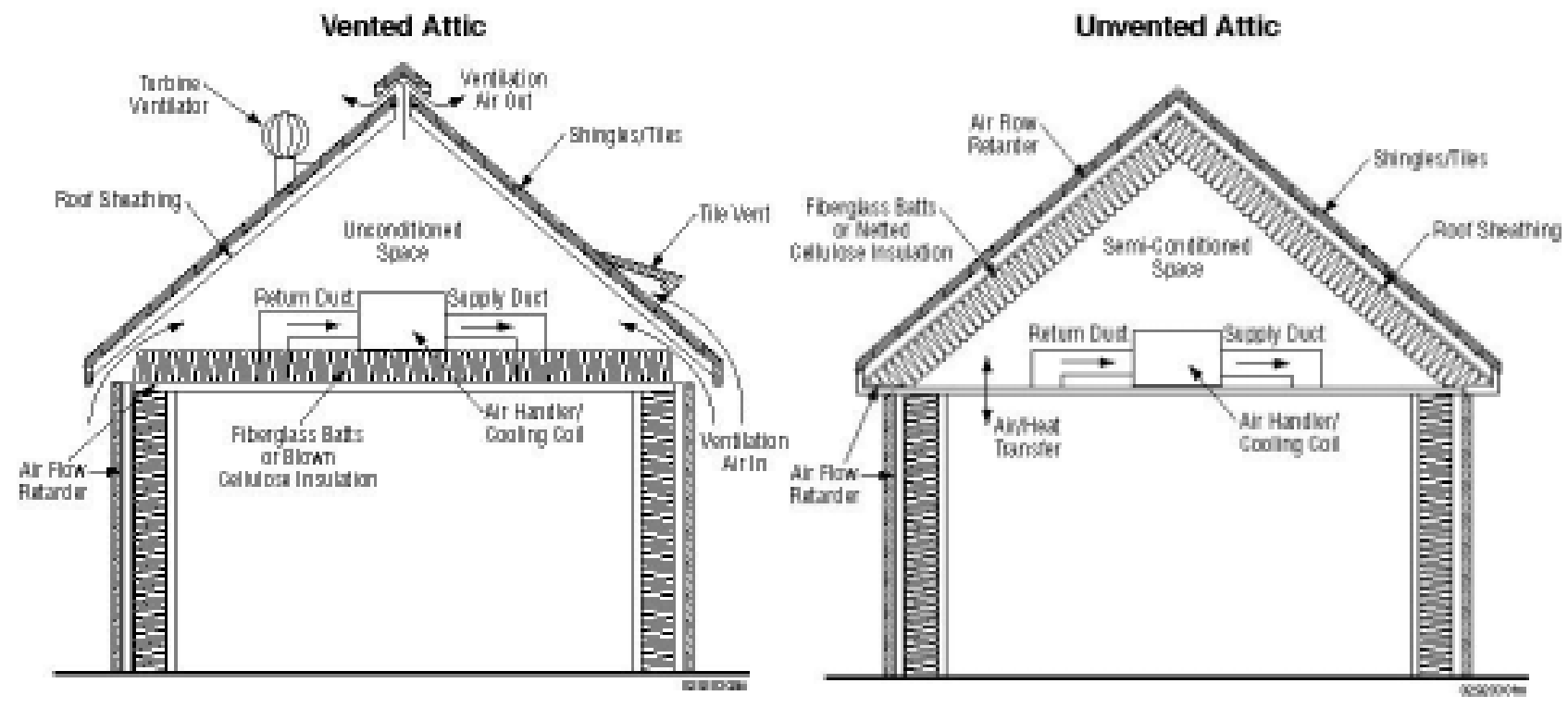

Figure 1. Vented and unvented attic concepts

The remainder of this report describes field-testing and analysis conducted by NREL and the Building America teams. The Building Science Consortium (BSC) has done the most extensive research in this area, and the two builder projects described in detail in the following sections were led by this partnership: Pulte Homes in Tucson and Watt Homes in Las Vegas. 


\section{Approach}

\section{Field-Testing of Vented and Unvented Attics}

Direct measurements of the performance characteristics of attics under realistic field conditions are very important when developing an accurate model that can estimate annual energy savings. It is extremely helpful if a side-by-side test can be conducted, where the only difference between two houses is the type of attic. This allows for the isolation of specific performance differences resulting from the unvented attic.

The most useful specific field measurements include the air temperatures of the attic and house interior, building loss coefficient $\left(\mathrm{UA}_{\mathrm{o}}{ }^{*}\right)$ and air infiltration determined during co-heating, change in UA and air infiltration resulting from air handler operation, effective leakage area as measured with a blower door, and duct leakage as measured with a duct blaster. It is also important to have access to local temperature, wind, and solar conditions. A thorough site audit should also be conducted to verify that all features of the house are as expected.

\section{Modeling an Unvented Attic Using DOE-2.2}

An accurate and detailed model of the attic is essential to capture the difference between a vented and unvented attic. The following discussion provides the general approach used by the authors to simulate the energy usage of houses with vented and unvented attics using DOE-2.2 $2^{\dagger}$. However, it is important to make specific judgments regarding the most reasonable modeling assumptions, and even the most appropriate modeling tool, in the context of the project at hand. Important considerations include the attic design, air leakage characteristics, and the local climate. It is also very important to use field test results to the largest extent possible as inputs to the model and to validate the results.

An accurate analytical comparison of the two attic types must capture a number of quite different heat flows. The following heat flows were considered the most important by the authors:

- Supply duct leakage, airflow loss to the attic

- Return duct leakage, airflow from the attic to the return airstream

- Conductive heat loss or gain from the ducts to the attic

- Conductive and radiative heat transfer between the attic and the outside

- Conductive heat transfer between the attic and the house

- Natural air exchange between the attic, the house, and the outside

- Mechanically induced air exchange between the attic, the house, and the outside.

\footnotetext{
${ }^{*} \mathrm{UA}_{\mathrm{o}}$ is often referred to as the building loss coefficient. It represents the rate of heat loss or gain of a house as a function of temperature between the inside and outside under steady-state conditions.

${ }^{\dagger}$ DOE-2.2 is an hourly building energy simulation software tool.
} 
Certain heat flows were deemed secondary in the context of this study and were not included in the simulations:

- Radiative heat transfer between the inside surface of the roof and the air ducts

- Radiative heat transfer between the inside surface of the roof and the attic floor.

The comparison of an unvented attic and a traditional vented attic involved rather complicated heat transfer paths that could not be entirely modeled using the standard options of DOE-2.2. One important example was return air leakage, which could not be directly modeled by DOE- 2.2 at the time the analysis was performed. On occasion, it was necessary to develop alternative modeling approaches that resulted in accurate energy calculations even though the model may not have directly resembled the physical features of the house. Specific details of the modeling assumptions used by the authors are addressed in the sections of this report describing each test.

For the vented scenario, illustrated in Figure 2, the attic was modeled as an unconditioned space. The attic air-exchange rate was specified as 1.5 air changes per hour $(\mathrm{ACH})$, or approximately $0.1 \mathrm{cfm}$ per square foot of attic area. ${ }^{*}$ Field-test measurements served as the basis for estimating the fraction of air leakage from the supply ducts that was lost to the outside and the fraction that remained in conditioned space. It was also important to accurately model return leaks caused by attic air entering the return airstream, because the temperature of the attic air was often quite different from either the return air or outside air.

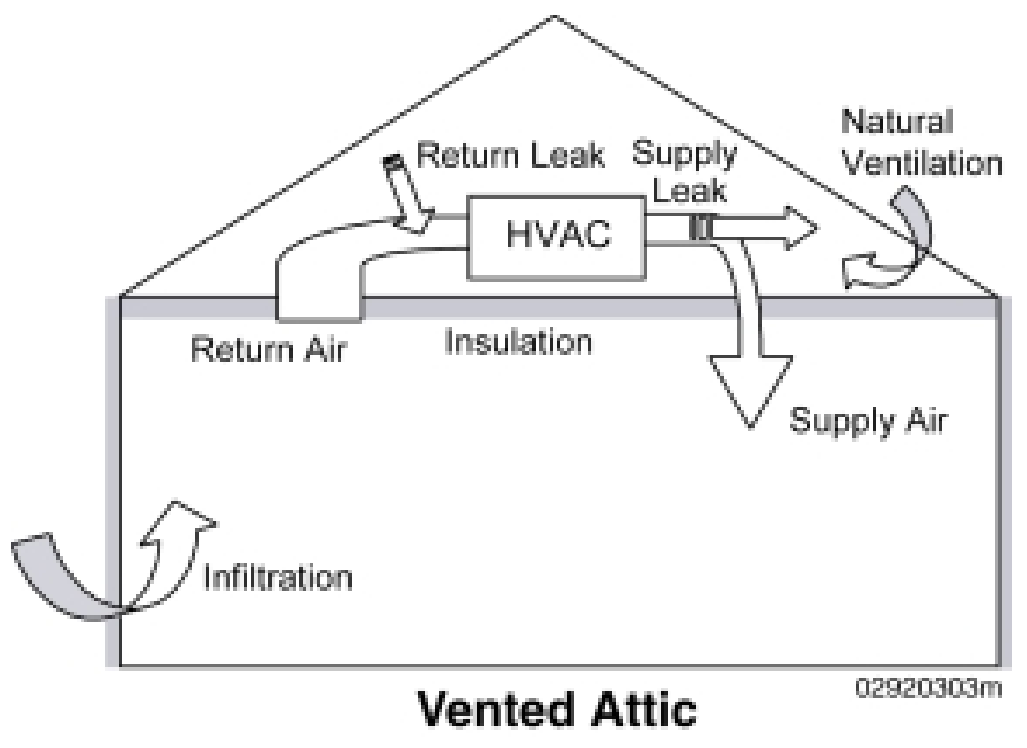

Figure 2. Vented attic airflows 
The unvented attic model (Figure 3 ) had the insulation in the roof portion of the attic, creating a much tighter space and reducing the natural ventilation in the attic. The attic was unintentionally conditioned by the supply air leaks and was modeled as a conditioned space in DOE-2.2. Duct leakage into the attic, which was measured during field-testing, was modeled using an equivalent flow rate of conditioned supply air.

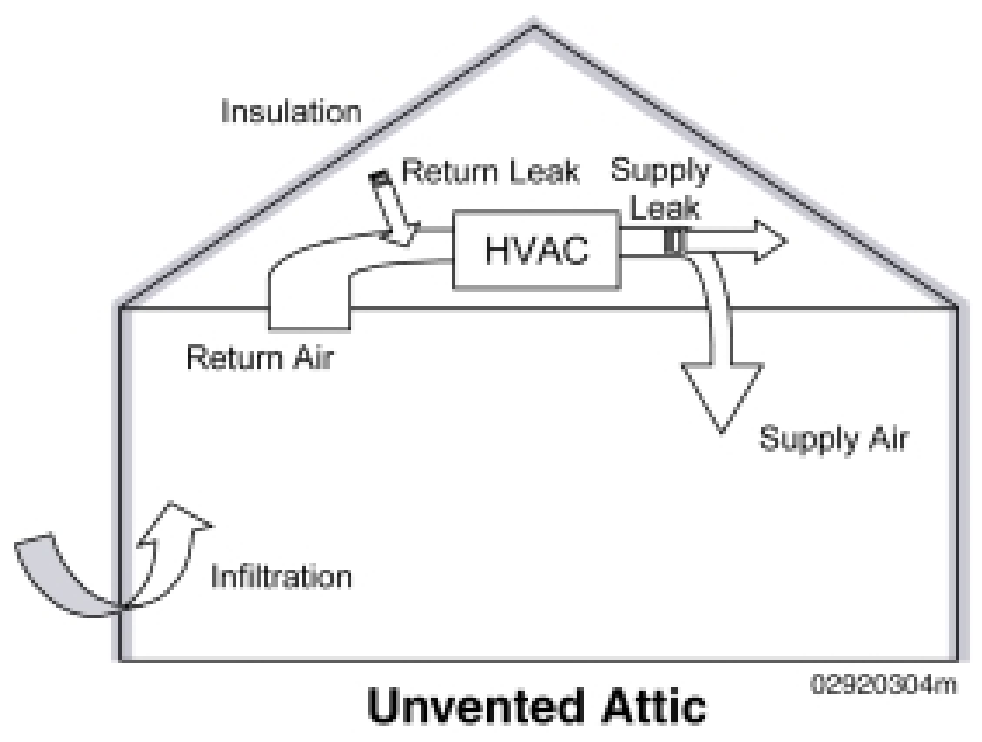

Figure 3. Unvented attic airflows

\section{Results}

\section{Case 1: Las Vegas, Nevada}

In 1998, field-testing of unvented attics was conducted during both the winter and summer seasons at communities built by Watt Homes in Las Vegas, Nevada. The tests conducted in the winter included a Building America prototype house with an unvented attic at the Four Seasons development and a similar base-case house at the Wildflower development. In addition to an unvented attic, the features that were different in the prototype house included an improved airdistribution system, controlled ventilation, and integrated hydronic heating. The prototype and base case also had different floor plans, conditioned area, window area, and window orientations. The tests conducted in the summer included two prototype houses of the same model, which were nearly identical except for the attic ventilation and the location and R-value of the attic insulation. These prototypes were not the same houses that were tested during the winter. 


\section{Winter Test}

One prototype and one base-case house (Figures 4 and 5) were tested in February 1998 to evaluate a series of design features implemented by Watt Homes in the Four Seasons community. The use of an unvented attic was one of several design changes made by the builder. Others included a combination domestic hot water (DHW) and space-heating system, a single air handler, low-e vinyl frame windows, reduced window area, and controlled ventilation. The prototype house was also a different model than the base case, with a different floor area, but the same north-facing orientation. Summaries of the specifications for both houses are presented in Table 2.

Table 2. Las Vegas Test House Descriptions (Winter)

\begin{tabular}{|c|c|c|}
\hline Item & Base Case & Prototype \\
\hline \multirow[t]{3}{*}{ Location } & Wildflower 3, Block 14/Lot 11 & Four Seasons, Lot 8 \\
\hline & 7741 Curiosity & 7621 Curiosity \\
\hline & Las Vegas, Nevada & Las Vegas, Nevada \\
\hline Model & $\begin{array}{l}\text { \#4234, 2-story, slab-on-grade, } 4 \\
\text { bedrooms }\end{array}$ & $\begin{array}{l}\text { \#4133, “Summer," 2-story, slab- } \\
\text { on-grade, } 3 \text { bedrooms }\end{array}$ \\
\hline Size & $2,080 \mathrm{ft}^{2}$ (standard plan, fireplace) & $1,742 \mathrm{ft}^{2}$ (standard plan) \\
\hline Front orientation & North & North \\
\hline Walls & 2x4, R-13 cavity, R-4 EPS ${ }^{*}$ & 2x4, R-13 cavity, R-4 EPS \\
\hline Roof & $\begin{array}{l}\text { Conventional/vented, R-30 } \\
\text { fiberglass, tile roof }\end{array}$ & $\begin{array}{l}\text { Unvented, R-30 fiberglass, tile } \\
\text { roof }\end{array}$ \\
\hline Windows & $\begin{array}{l}\text { Double-pane, clear, aluminum } \\
\text { frame, } 393 \mathrm{ft}^{2} \text { glazing area }\end{array}$ & $\begin{array}{l}\text { Double-pane, low-e, vinyl frame, } \\
255 \mathrm{ft}^{2} \text { glazing area }\end{array}$ \\
\hline Ventilation & None & $\begin{array}{l}\text { Controlled supply, 4-in. outside } \\
\text { air duct to return of air handler, } \\
\text { manual damper, FanRecycler } \\
\text { control }\end{array}$ \\
\hline Heating & $\begin{array}{l}\text { Two furnace systems, nominal } \\
80 \% \mathrm{AFUE}^{\dagger}, 50 \mathrm{kBtu} / \mathrm{hr} \text { each }\end{array}$ & $\begin{array}{l}\text { Hydronic combined system, } \\
\text { nominal } 0.55 \mathrm{EF}^{\S}, 75 \% \\
\text { recovery efficiency, } 63 \mathrm{kBtu} / \mathrm{hr} \\
\text { input }\end{array}$ \\
\hline Cooling & Two 3.0-ton $\mathrm{A} / \mathrm{C}$ units & One 3.5-ton $\mathrm{A} / \mathrm{C}$ unit \\
\hline $\begin{array}{l}\text { Air handler and duct } \\
\text { location }\end{array}$ & In vented attic & In unvented attic \\
\hline Distribution power & Two 400-watt fans & 800 -watt fan +100 -watt pump \\
\hline
\end{tabular}

\footnotetext{
${ }^{*}$ Expanded polystyrene

${ }^{\dagger}$ Annual Fuel Utilization Efficiency

$\S$ Energy Factor
} 

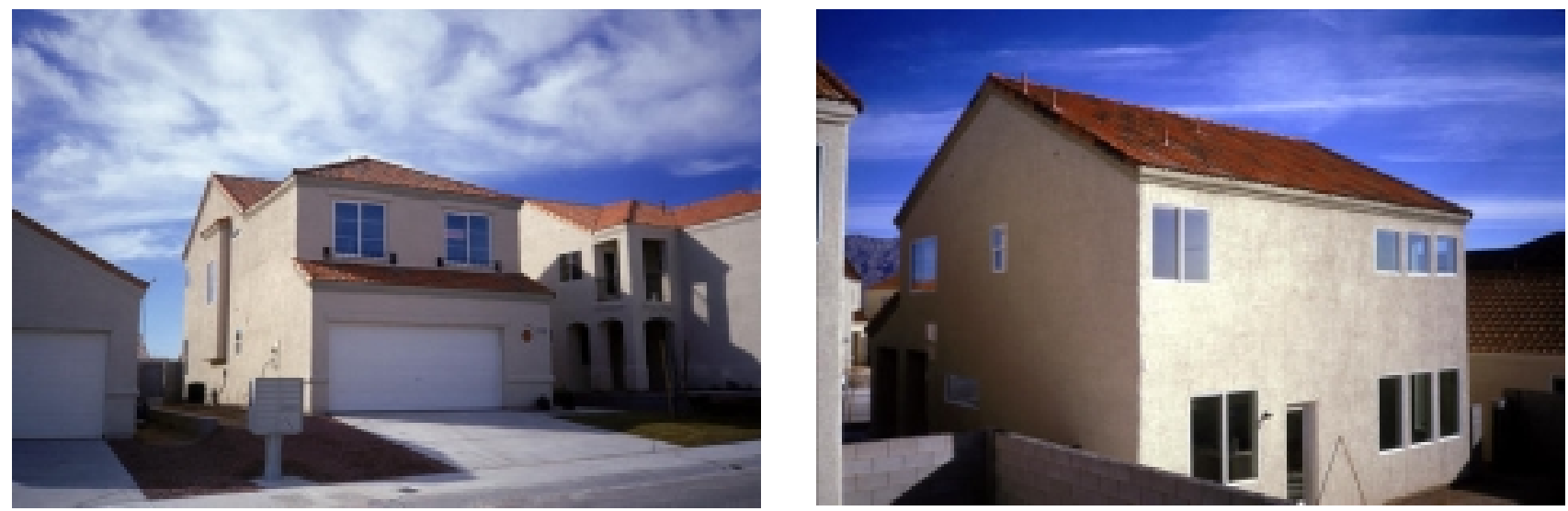

Figure 4. Front and rear views of first Las Vegas prototype house
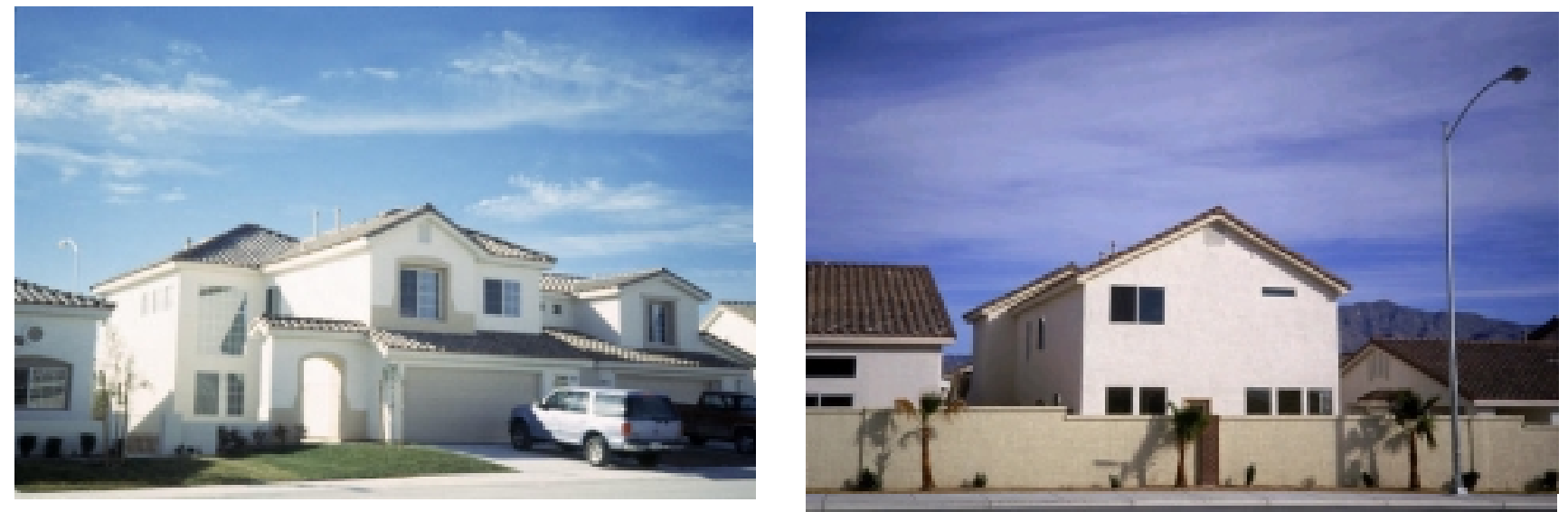

Figure 5. Front and rear views of first Las Vegas base-case house

The weather conditions during the 9-day test period were fairly typical, mild winter days in Las Vegas. The days were mostly sunny. Wind speeds were light during the first few days, but increased later in the week. Temperature and wind speed during the test period are plotted in Figures 6 and 7. The thermostat setpoints were maintained at $24^{\circ} \mathrm{C}\left(76^{\circ} \mathrm{F}\right)$ throughout the test. Inside temperatures were controlled using an electric co-heating system until Saturday morning, when the tests were conducted with normal operation of the heating system. The inside temperature occasionally rose above the setpoint during sunny afternoons, when solar heat gain exceeded the heating load. 


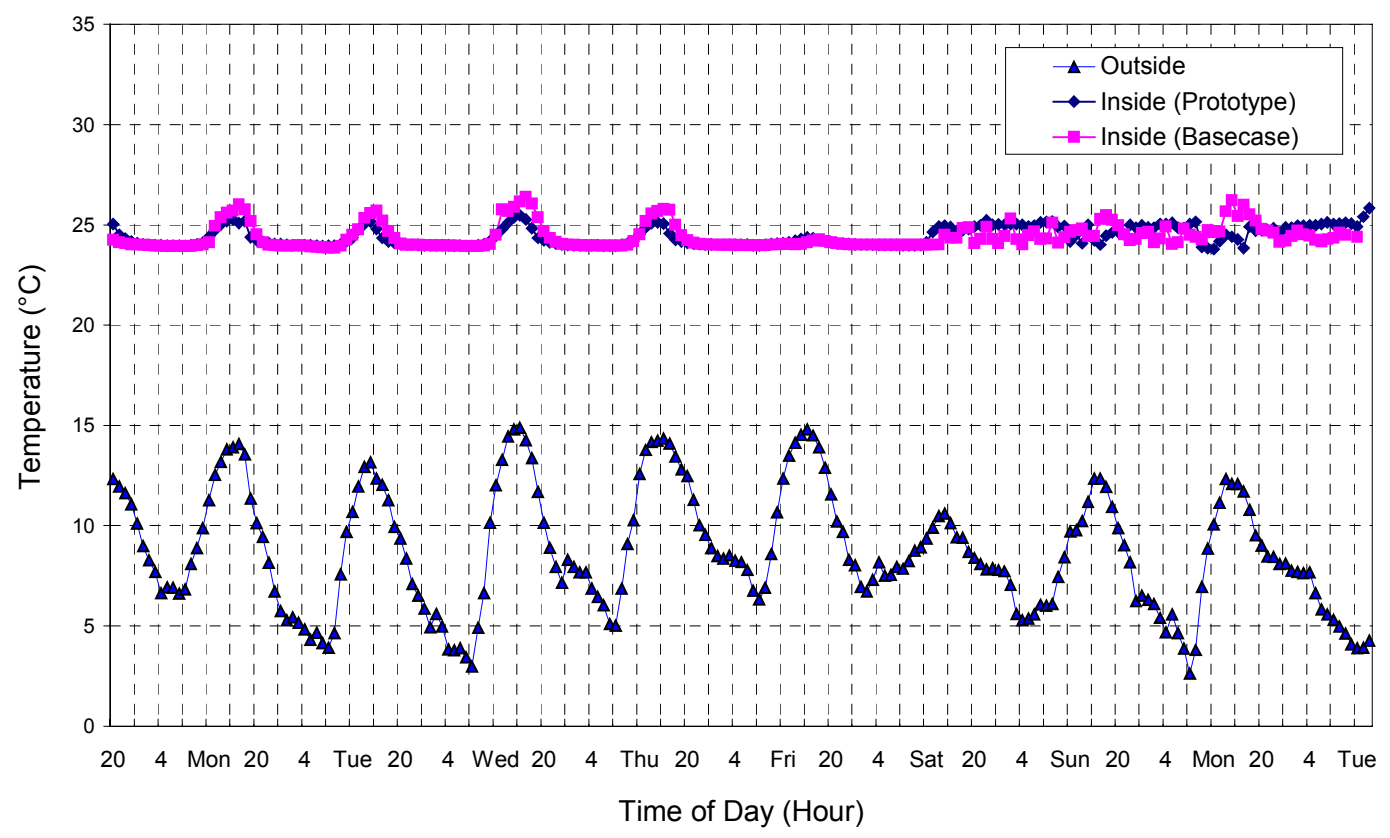

Figure 6. The difference between inside and outside temperatures varied from $10^{\circ}$ to $20^{\circ} \mathrm{C}\left(18^{\circ}\right.$ to $\left.36^{\circ} \mathrm{F}\right)$ during the 9 -day winter test period

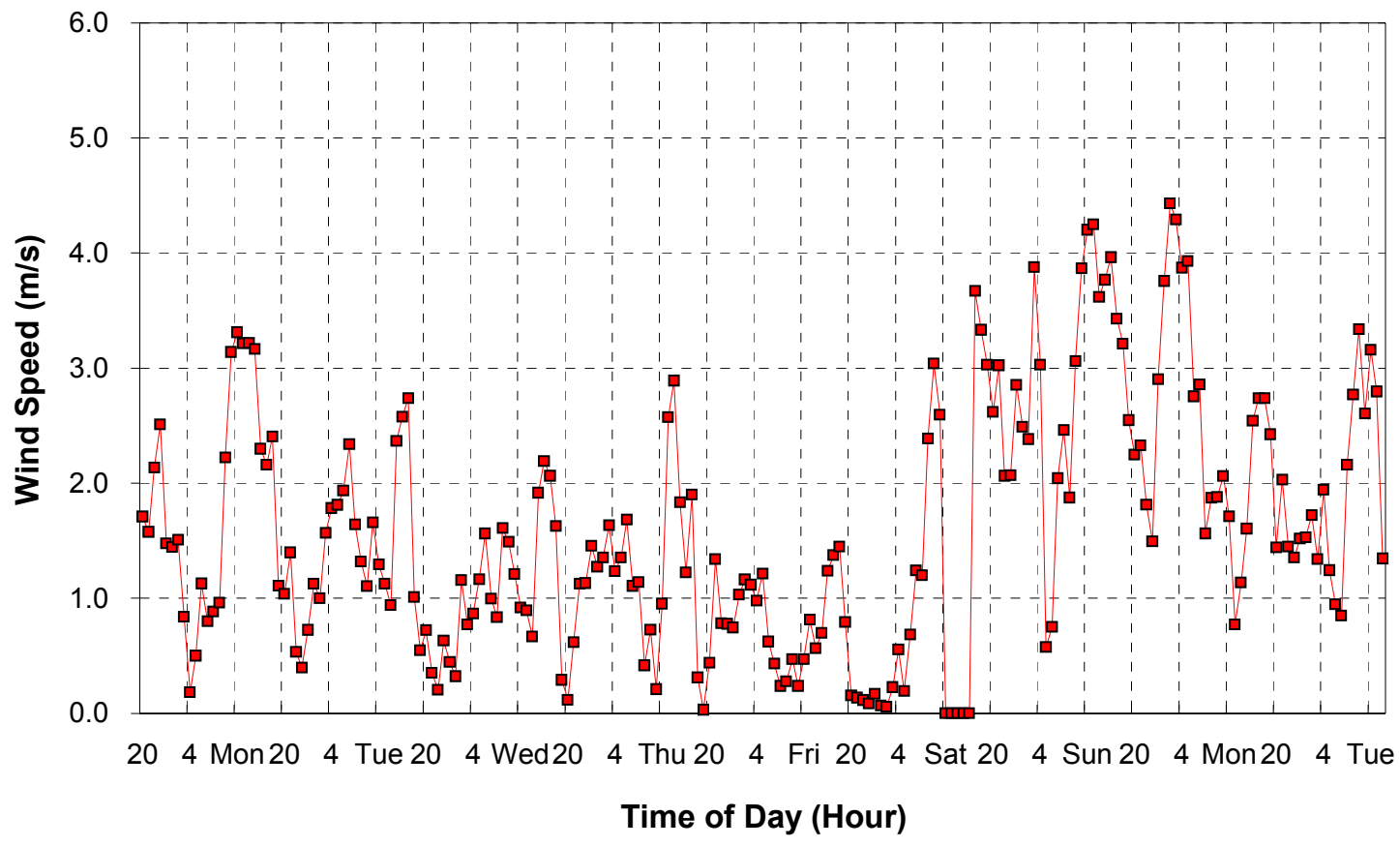

Figure 7. Wind speed reached about $4 \mathrm{~m} / \mathrm{s}(9 \mathrm{mi} / \mathrm{hr})$ late in the 9-day test period 
Tracer gas, blower door, duct blaster, co-heating, and submetering were used to measure wholebuilding performance with the conventional conditioned space as the control volume (i.e., not including the attic space). Representatives of BSC and the Florida Solar Energy Center (FSEC) performed the blower door and duct blaster tests for these houses, while NREL conducted tracer gas and co-heating tests. Co-heating was used for three nights in order to measure simple building UA and natural infiltration. Another night of co-heating was performed while the air-distribution fan was running to measure the fan-induced infiltration. An additional night of co-heating was performed while the air-distribution fan was running and the supply ventilation duct was open. The houses were then run with the installed heating systems in normal operation for three nights, with the best comparative data on the last night.

The air leakage and ventilation test results are summarized in Table 3. An uncertainty of approximately $5 \%$ for these blower door and duct blaster measurements can be expected when the equipment is used in accordance with standard industry practice. The hourly $\mathrm{ACH}$ for the two houses as measured by a tracer gas is shown in Figure 8, with a summary in Table 4. The air handlers were operated at $100 \%$ duty cycle on certain nights to determine fan-induced infiltration. In the base case, only one air handler at a time was operated. The outside air duct was taped off in the prototype house during the first two nights of air handler operation. The tape was removed for the ventilation test on Thursday night. In addition to being significantly more airtight, the prototype house lost much less air to the outside from the ducts. These improvements cannot necessarily be attributed to the unvented attic because special attention was given to the prototype to make it more airtight, but the results provide a strong indication that the attic was well sealed. A well-sealed roof plane is a vital attribute of a well-designed unvented attic.

Table 3. Air-Leakage Measurements

\begin{tabular}{|c|c|c|}
\hline Item & $\begin{array}{c}\text { Base case } \\
\left(2,080 \mathrm{ft}^{2}, 19 \% \text { window/ }\right. \\
\text { floor area, no fireplace })\end{array}$ & $\begin{array}{c}\text { Prototype } \\
\left(1,742 \mathrm{ft}^{2}, 15 \% \text { window/ }\right. \\
\text { floor area, no fireplace })\end{array}$ \\
\hline Effective leakage area (ELA) $\left(\right.$ in. $^{2}$ ) & $110 \pm 5$ & $50 \pm 3$ \\
\hline Natural infiltration $(\mathrm{ACH})$ & $0.25-0.35$ & $0.10-0.15$ \\
\hline Total duct leakage & $166 \pm 10$ downstairs unit & $215 \pm 10$ \\
\hline (cfm @ $25 \mathrm{~Pa})$ & $232 \pm 10$ upstairs unit & \\
\hline Duct leakage to outside & $74 \pm 4$ downstairs unit & $<19$ \\
\hline (cfm @ $25 \mathrm{~Pa})$ & $86 \pm 4$ upstairs unit & \\
\hline \multirow[t]{2}{*}{ Fan-induced infiltration $(\mathrm{ACH})$} & $0.10 \pm 0.01$ & $0.00 \pm 0.01$ \\
\hline & (Per fan) & (Outside air taped-off) \\
\hline Ventilation flow measured by duct blaster (cfm) & $\mathrm{N} / \mathrm{A}$ & $30 \pm 2(0.10 \pm 0.005 \mathrm{ACH})$ \\
\hline Ventilation flow measured by tracer gas $(\mathrm{ACH})$ & $\mathrm{N} / \mathrm{A}$ & $0.07 \pm 0.01$ \\
\hline
\end{tabular}




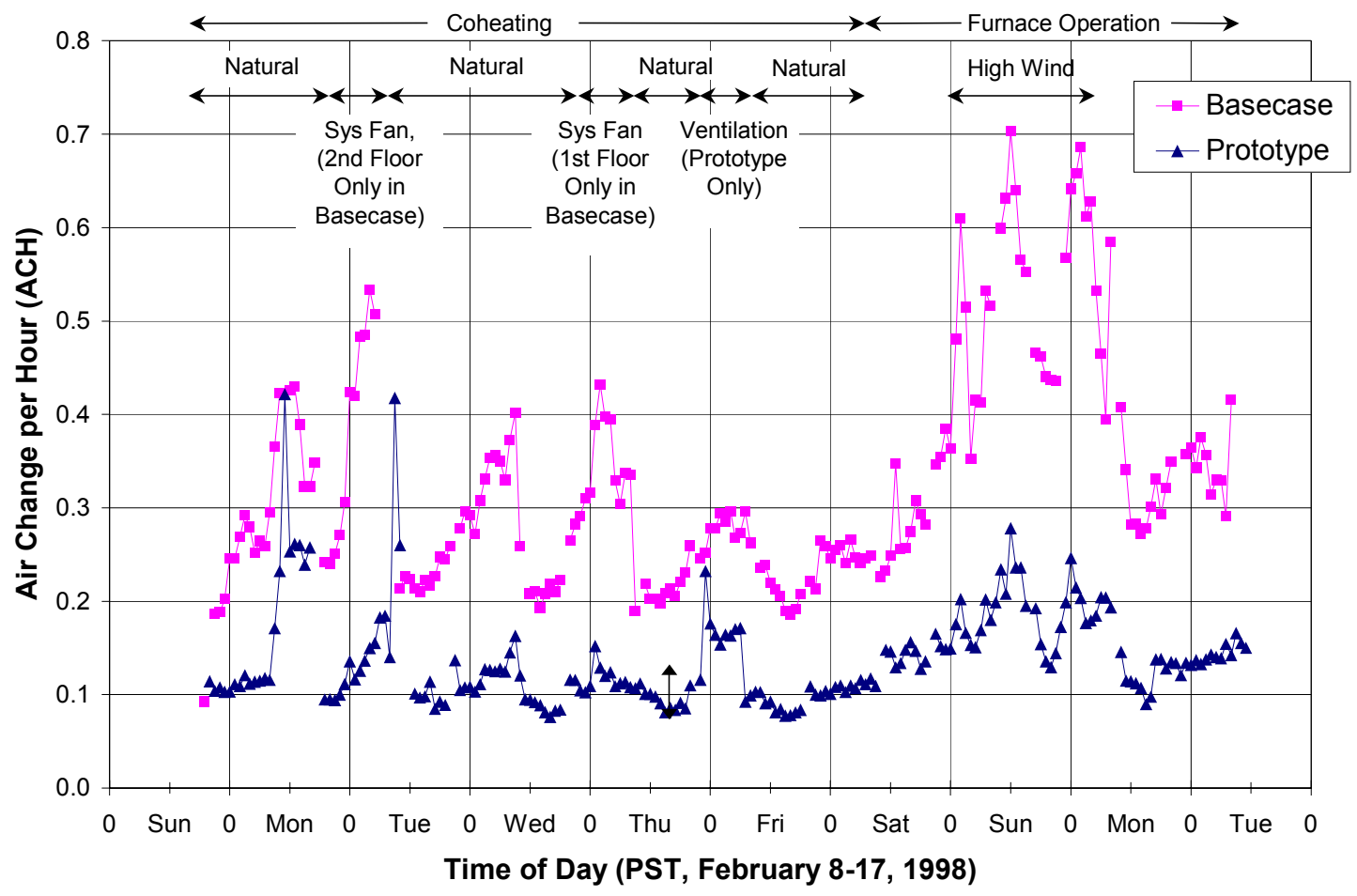

Figure 8. Air infiltration during periods of co-heating and normal furnace operation as measured by a tracer gas

Table 4. Summary of Tracer Gas Test Results during Nighttime Test Periods (11:00 p.m. to 5:00 a.m.)

\begin{tabular}{|c|c|c|c|c|c|c|c|c|c|c|c|c|c|}
\hline \multirow{2}{*}{\multicolumn{2}{|c|}{$\begin{array}{l}\text { Operating } \\
\text { Conditions }\end{array}$}} & \multicolumn{2}{|c|}{$\begin{array}{c}\text { Co-heating, } \\
\text { Natural } \\
\text { Infiltration }\end{array}$} & \multicolumn{2}{|c|}{$\begin{array}{l}\text { Co-heating } \\
\text { w/ Air } \\
\text { Handler ( } 2^{\text {nd }} \\
\text { Floor in } \\
\text { Base Case) }\end{array}$} & \multicolumn{2}{|c|}{$\begin{array}{l}\text { Co-heating } \\
\text { w/ Air } \\
\text { Handler (1 } \\
\text { Floor in } \\
\text { Base Case) }\end{array}$} & \multicolumn{2}{|c|}{$\begin{array}{c}\text { Co-heating, } \\
\text { w/ } \\
\text { Ventilation } \\
\text { (Prototype } \\
\text { Only) }\end{array}$} & \multicolumn{2}{|c|}{$\begin{array}{c}\text { Furnace, } \\
\text { Normal } \\
\text { Wind }\end{array}$} & \multicolumn{2}{|c|}{$\begin{array}{l}\text { Furnace, } \\
\text { High Wind }\end{array}$} \\
\hline & & Base & Proto & Base & Proto & Base & Proto & Base & Proto & Base & Proto & Base & Proto \\
\hline & Average $\mathrm{ACH}$ & 0.27 & 0.11 & 0.45 & 0.13 & 0.37 & 0.12 & 0.28 & 0.17 & 0.35 & 0.14 & 0.56 & 0.19 \\
\hline & $\begin{array}{l}\text { Average } \\
\text { Wind Speed } \\
(\mathrm{m} / \mathrm{s})\end{array}$ & \multicolumn{2}{|c|}{0.73} & \multicolumn{2}{|c|}{1.42} & \multicolumn{2}{|c|}{1.43} & \multicolumn{2}{|c|}{0.98} & \multicolumn{2}{|c|}{1.73} & \multicolumn{2}{|c|}{3.05} \\
\hline \multirow[t]{2}{*}{ 蒿 } & $\begin{array}{l}\text { Average } \Delta \mathrm{T} \\
\left({ }^{\circ} \mathrm{C}\right)\end{array}$ & \multicolumn{2}{|c|}{17.3} & \multicolumn{2}{|c|}{18.9} & \multicolumn{2}{|c|}{16.7} & \multicolumn{2}{|c|}{15.7} & \multicolumn{2}{|c|}{17.5} & \multicolumn{2}{|c|}{19.3} \\
\hline & $\begin{array}{l}\text { Average } \\
\text { Natural Gas } \\
\text { for Heating, } \\
\text { Normalized } \\
\text { by Floor Area } \\
\left(\mathrm{ft}^{3} / \mathrm{hr}^{3} \mathrm{ft}^{2}\right)\end{array}$ & 0 & 0 & 0 & 0 & 0 & 0 & 0 & 0 & 0.012 & 0.011 & 0.017 & 0.013 \\
\hline
\end{tabular}


The attic temperature profiles for both houses during the test period are shown in Figure 9. The unvented attic very nearly tracks the interior temperature. This implies that the attic is very well insulated at the roof plane, the attic is thermally well connected to the house, or there is substantial air leakage from the supply ducts into the attic space that counteracts heat loss through the roof. The small change in air infiltration measured by the tracer gas when the air handler is operating would lead one to the conclusion that the attic is well connected to the house and that the roof is at least reasonably airtight. The vented attic in the base-case house is significantly warmer than the outside during the day because the sunshine heats the attic air. Unfortunately, the temperature drops at night when the heating system is operating at the highest duty cycle and duct leakage is most detrimental.

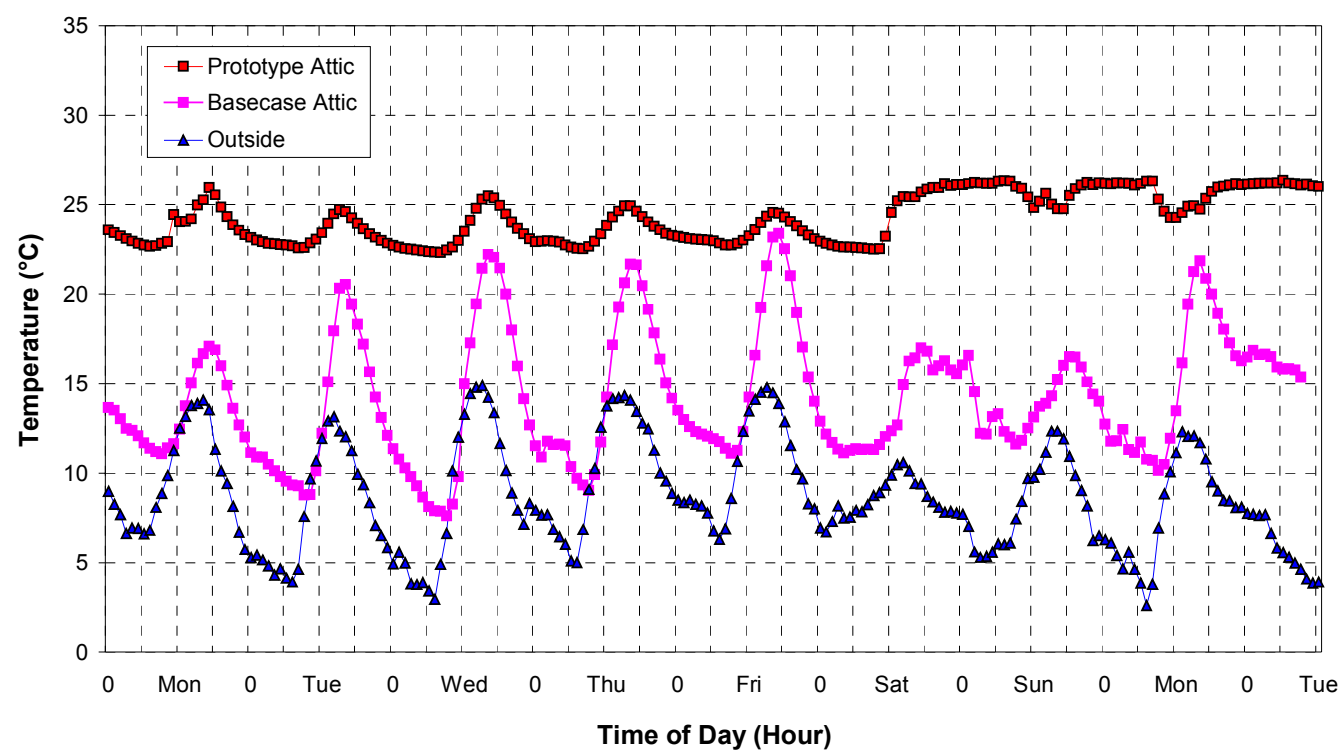

Figure 9. Attic temperatures relative to outside temperatures during test period

\section{Key Findings}

- Energy losses associated with duct air leakage appeared to be negligible for the unvented attic, as indicated by the tracer gas measurements of heating system fan-induced infiltration.

- The unvented attic temperature tracked the interior temperature very well, resulting in a very mild environment for the ducts during the winter test period. The vented attic temperature was approximately midway between the inside and outside temperatures. 


\section{Summer Test}

In partnership with BSC, NREL tested a second pair of prototype and base-case houses (Figures 10 and 11) built by Watt Homes in August 1998 to examine the performance of an unvented attic in hot summer conditions. This time the two test houses were nearly identical except for the unvented attic and the smaller attic R-value in the prototype (R-22 at the roof, compared to R-30 at the ceiling). Summaries of the specifications for both houses are presented in Table 5.

Table 5. Las Vegas Test House Descriptions (Summer)

\begin{tabular}{|c|c|c|}
\hline & Vented Attic & Unvented Attic \\
\hline \multirow{3}{*}{$\begin{array}{l}\text { Development } \\
\text { location }\end{array}$} & Four Seasons, Lot 26 & Four Seasons, Lot 24 \\
\hline & 7620 Adornment Court & 7612 Adornment Court \\
\hline & Las Vegas, Nevada & Las Vegas, Nevada \\
\hline \multirow[t]{3}{*}{ Model } & Spring, Plan \# 4113 & Same (with slope end over garage) \\
\hline & 1-story, slab-on-grade, 3 bedrooms & \\
\hline & (with gable end over garage) & \\
\hline Size & $1,350 \mathrm{ft}^{2}$ & Same \\
\hline Front orientation & South & Same \\
\hline Garage & Right side & Same \\
\hline \multirow{3}{*}{$\begin{aligned} \text { Insulation } & - \text { Walls } \\
& - \text { Attic }\end{aligned}$} & $\mathrm{R}-13$ cellulose & Same \\
\hline & $\begin{array}{l}\text { R-30 cellulose at ceiling, vented, } \\
\text { tile roof }\end{array}$ & $\begin{array}{l}\text { R-22 cellulose at roof plane, } \\
\text { unvented, tile roof }\end{array}$ \\
\hline & None (carpet pad installed) & Same \\
\hline \multirow[t]{2}{*}{ Windows } & Double-pane, vinyl frame & Same \\
\hline & PPG Sungate-1000 glazing & \\
\hline Ventilation & $\begin{array}{l}\text { O/A duct to return air plenum, } \\
\text { manual damper, FanRecycler } \\
\text { control (disabled for testing) }\end{array}$ & Same \\
\hline \multirow[t]{3}{*}{ Ducts } & Air handler in attic & Same \\
\hline & Supply ducts in attic & \\
\hline & 2 return ducts, hall \& mstr bdrm & \\
\hline Cooling & $\begin{array}{l}2.5 \text { tons, 10 SEER with equivalent } \\
\text { refrigerant charge }\end{array}$ & Same \\
\hline Heating & Hydronic heating with DHW & Same \\
\hline $\begin{array}{l}\text { Air distribution fan } \\
\text { (measured) }\end{array}$ & $500 \mathrm{~W}$ for approx. $1,100 \mathrm{cfm}$ & Same \\
\hline
\end{tabular}



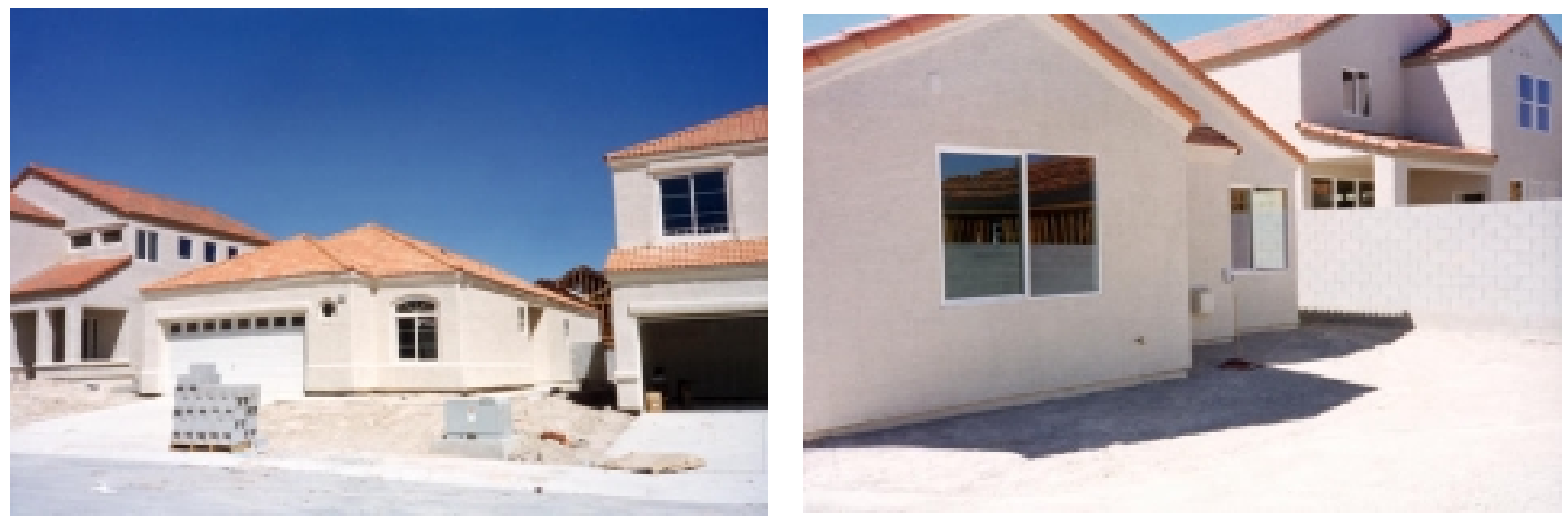

Figure 10. Front and rear views of second Las Vegas prototype house

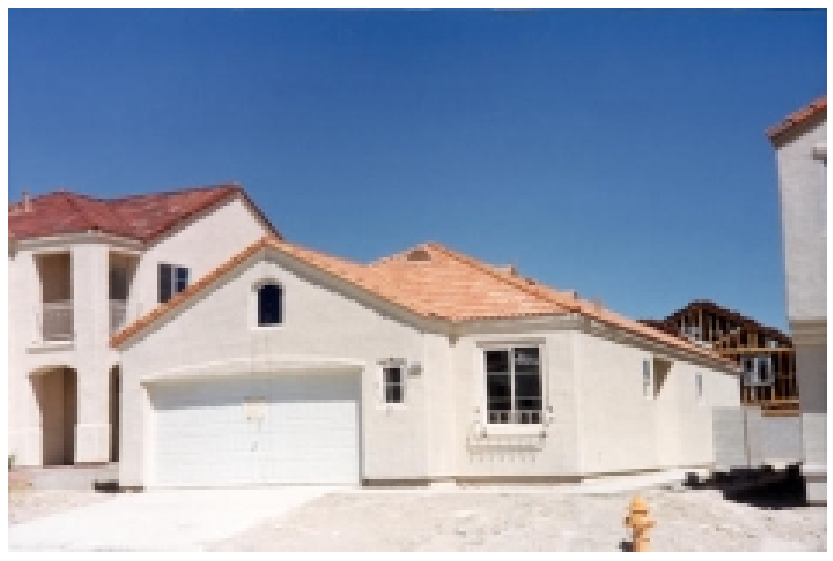

Figure 11. Front view of second Las Vegas base-case house

Tracer gas and submetering techniques were used to measure whole-building performance for the prototype and base-case houses. The nominal thermostat setpoint in both houses was $24^{\circ} \mathrm{C}$ $\left(75^{\circ} \mathrm{F}\right)$.

Four test conditions were established to evaluate the effects of duct leakage on the performance of the two attics. These conditions were in effect at the same time in both houses. Holes were cut in the supply and return air plenums to create the desired amount of duct leakage. Pressure drop across a calibrated orifice plate was used to verify the leakage rate for Cases 2 and 3: 
Case 1. Tight Ducts:

Case 2. 100-cfm Supply Leak

Case 3. 100-cfm Supply and 100-cfm Return:

Case 4. Additional Supply Leakage:
Estimated 30-cfm total duct leakage as measured using a duct blaster.

Same as Case 1 with a hole in the supply air plenum that leaked $100 \mathrm{cfm}$ out of the system at normal operating pressure.

Same as Case 2 with a hole in the return air plenum that leaked $100 \mathrm{cfm}$ into the system at normal operating pressure.

Same as Case 3 with an enlarged hole in the supply air plenum. Although this case is not representative of observed levels of duct leakage, it was included in the test plan to provide an upper extreme.

Weather conditions during the test period were hot and sunny with mild winds (Figures 12 and 13). Outside temperatures peaked over $38^{\circ} \mathrm{C}\left(100^{\circ} \mathrm{F}\right)$ every day, except Tuesday, and dropped down to $21^{\circ}-27^{\circ} \mathrm{C}\left(70^{\circ}-80^{\circ} \mathrm{F}\right)$ at night. Inside temperatures were well controlled at about $24^{\circ} \mathrm{C}$ $\left(75^{\circ} \mathrm{F}\right)$ throughout the test.

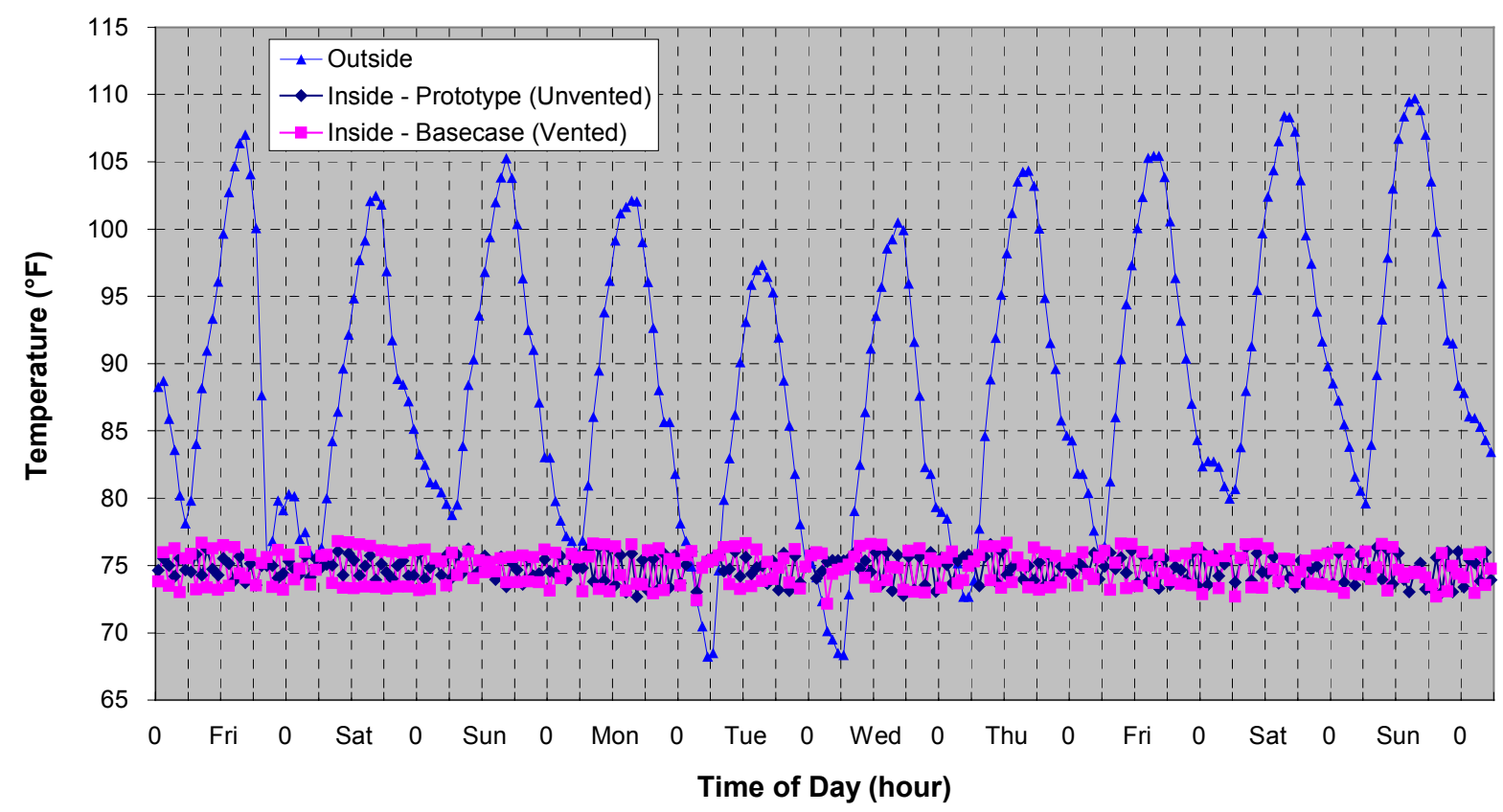

Figure 12. Outdoor and indoor temperatures during the summer test period 


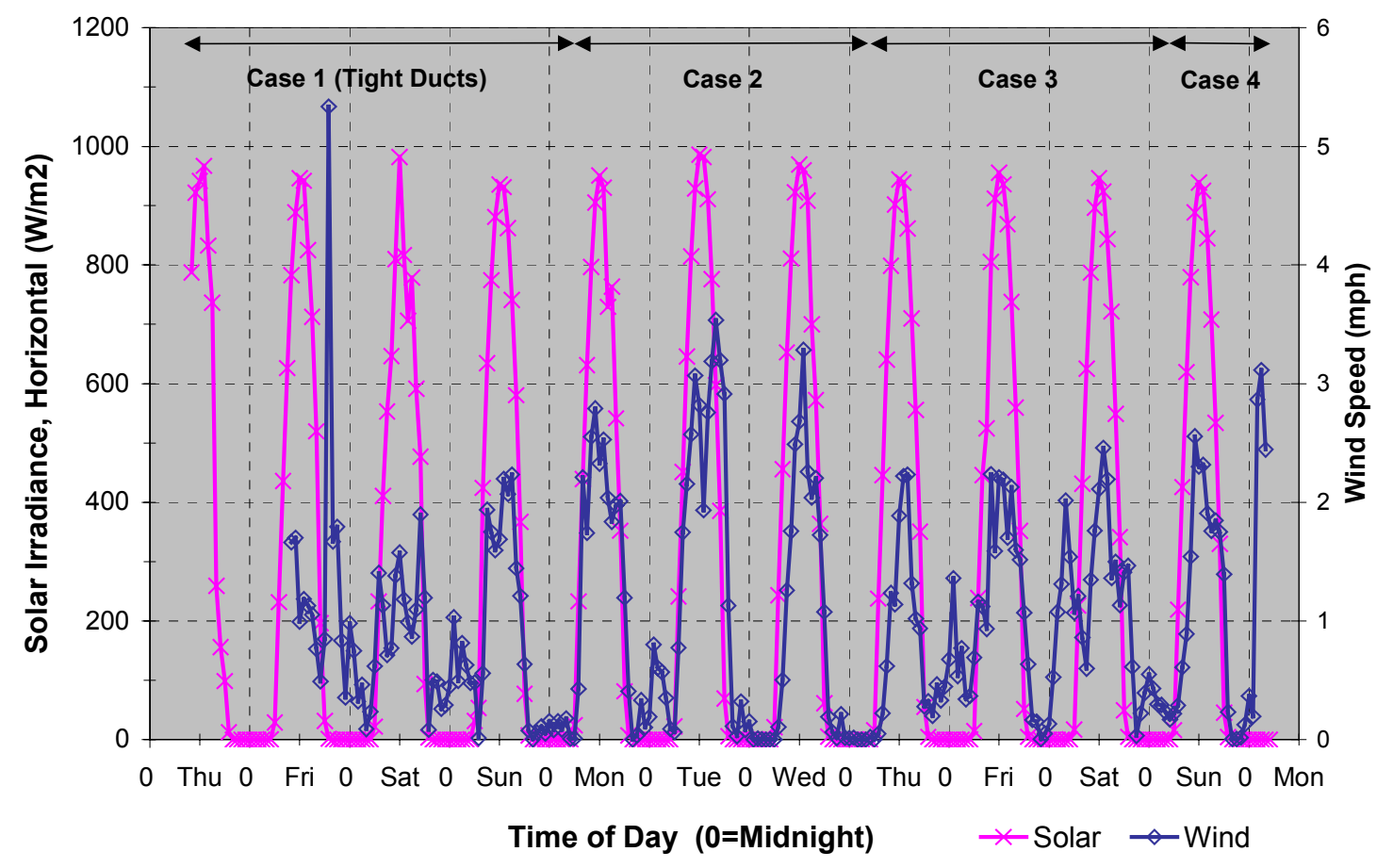

Figure 13. Solar insolation and wind speed during the summer test period

The total air infiltration was measured using a tracer gas for each test house while applying the four duct-leakage conditions. The ventilation system was made inactive during the test period by disabling the FanRecycler. The hourly results are shown in Figure 14 and summarized in Table 6. Air infiltration for each house was very small during normal cooling system operation before additional duct leaks were introduced (Case 1). The prototype house was slightly less airtight on average, but no definite conclusion can be drawn about the tightness of the unvented attic. As one would expect, the unvented attic was significantly less sensitive to increases in duct leakage because the ducts are within the conditioned space of the house. 


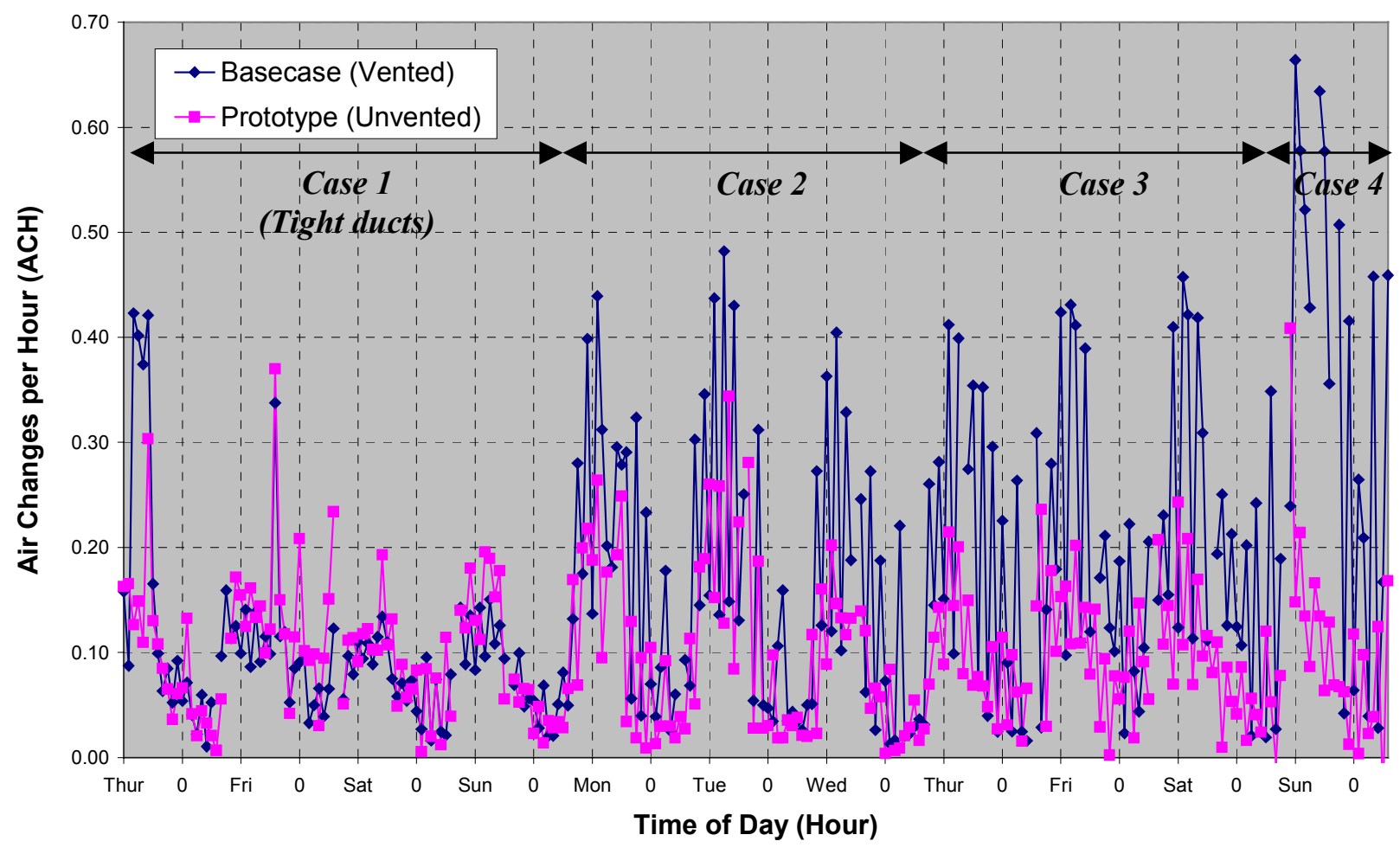

Figure 14. Air infiltration during the summer test period as measured by a tracer gas

Table 6. Summary of Tracer Gas Test Results During Daytime Test Periods (10:00 a.m. to 4:00 p.m.)

\begin{tabular}{|c|c|c|c|c|c|c|c|c|c|}
\hline \multirow{2}{*}{\multicolumn{2}{|c|}{$\begin{array}{l}\text { Operating } \\
\text { Conditions }\end{array}$}} & \multicolumn{2}{|c|}{$\begin{array}{l}\text { Case 1: Tight } \\
\text { Ducts }\end{array}$} & \multicolumn{2}{|c|}{$\begin{array}{l}\text { Case 2: } 100- \\
\text { cfm Supply } \\
\text { Leak }\end{array}$} & \multicolumn{2}{|c|}{$\begin{array}{l}\text { Case 3: } 100- \\
\text { cfm Supply and } \\
\text { Return Leaks }\end{array}$} & \multicolumn{2}{|c|}{$\begin{array}{c}\text { Case 4: } \\
\text { Additional } \\
\text { Supply Leakage }\end{array}$} \\
\hline & & Base & Proto & Base & Proto & Base & Proto & Base & Proto \\
\hline \multirow{4}{*}{ 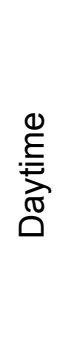 } & Average $\mathrm{ACH}$ & 0.11 & 0.14 & 0.26 & 0.18 & 0.28 & 0.14 & 0.49 & 0.19 \\
\hline & $\begin{array}{l}\text { Average Wind } \\
\text { Speed (mi/hr) }\end{array}$ & \multicolumn{2}{|c|}{1.40} & \multicolumn{2}{|c|}{2.51} & \multicolumn{2}{|c|}{1.78} & \multicolumn{2}{|c|}{2.03} \\
\hline & Average $\Delta \mathrm{T}\left({ }^{\circ} \mathrm{C}\right)$ & \multicolumn{2}{|c|}{13.3} & \multicolumn{2}{|c|}{11.8} & \multicolumn{2}{|c|}{14.9} & \multicolumn{2}{|c|}{17.9} \\
\hline & $\begin{array}{l}\text { Avg A/C Power } \\
(\mathrm{kW})\end{array}$ & 1.79 & 1.74 & 1.62 & 1.54 & 1.98 & 1.73 & 2.90 & 2.09 \\
\hline
\end{tabular}




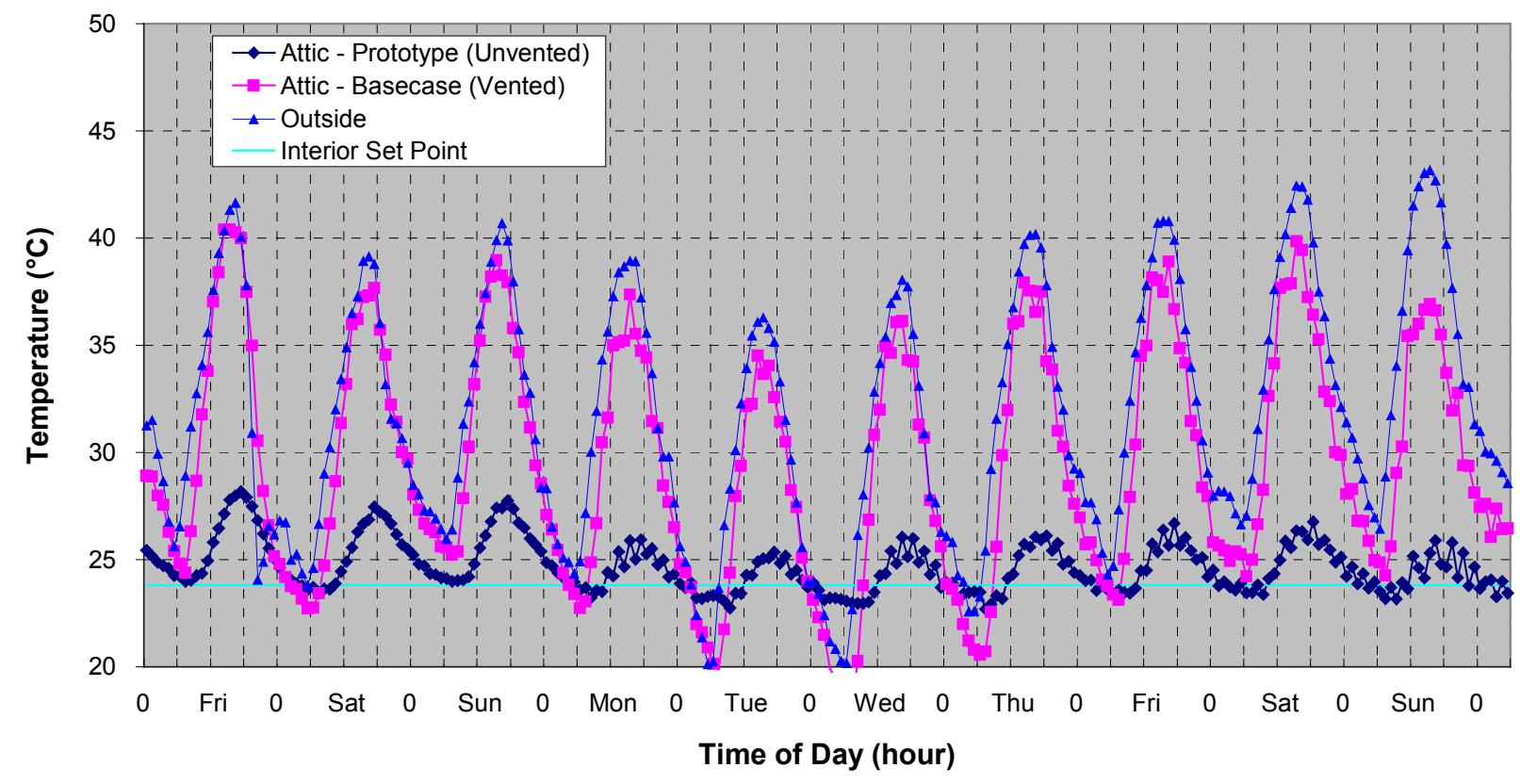

Figure 15. Attic temperatures during the summer test period

Attic temperatures for the two test houses are shown in Figure 15. The unvented attic very closely tracked the interior temperature of the house. This demonstrated that the unvented attic was thermally well connected to the interior conditioned space. Meanwhile the vented attic temperature was approximately the same as the outside temperature. In many attics the temperature would have been much higher during the summer, but not in this case because the tile roof reflected much of the solar radiation, thereby reducing solar heat gain.

The hourly power consumption for each test house is shown in Figure 16 and summarized on a daily basis in Table 7. The electric power consumption was very similar for the two test houses during the first 3 days when the ducts were tight. The house with the unvented attic used significantly less energy during the last few days when the ducts were the most leaky.

When interpreting these results, it is important to note that the unvented attic is only insulated to R-22, compared to R-30 for the vented attic. A smaller R-value is not an inherent characteristic of unvented attics. A larger thermal envelope surface area can be expected with an unvented attic as described in this report, leading to greater heat loss for the same insulation R-value. 


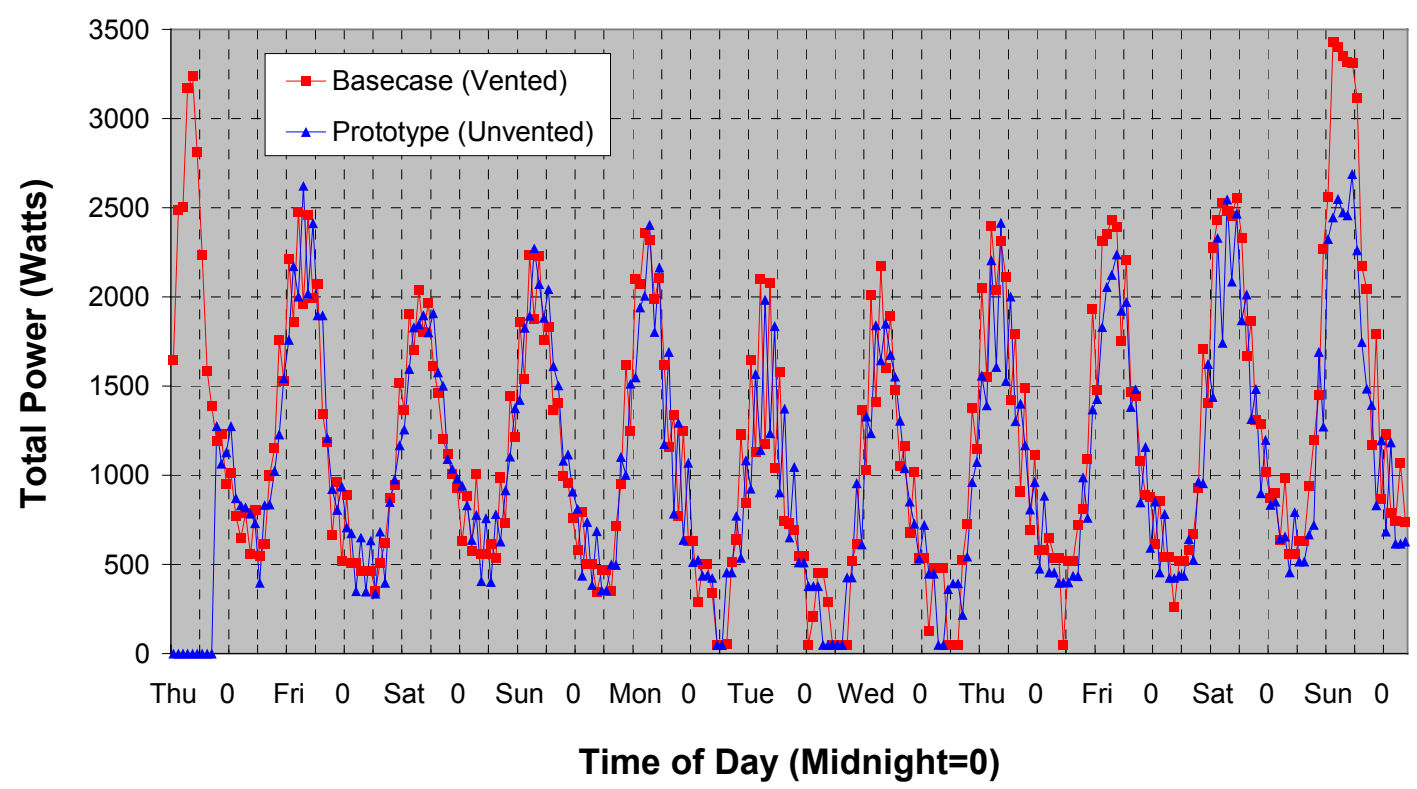

Figure 16. Hourly power measurements during the summer test period

Table 7. Daily Electricity Measurements During the Summer Test Period (kWh)

\begin{tabular}{ccccc}
\hline Day & Duct Leakage & $\begin{array}{c}\text { Base case } \\
\text { (Vented) }\end{array}$ & $\begin{array}{c}\text { Prototype } \\
\text { (Unvented) }\end{array}$ & $\begin{array}{c}\text { Percent } \\
\text { Difference }\end{array}$ \\
\hline Friday & Tight & 29.9 & 30 & 0.3 \\
Saturday & Tight & 27.2 & 27 & -0.7 \\
Sunday & Tight & 27.6 & 28.9 & 4.7 \\
Monday & 100-cfm supply & 27.2 & 25.6 & -5.9 \\
Tuesday & 100-cfm supply & 18.8 & 18.3 & -2.7 \\
Wednesday & 100-cfm supply & 20.8 & 19.9 & -4.3 \\
Thursday & $100-c f m$ supply and return & 26.7 & 25.7 & -3.7 \\
Friday & 100-cfm supply and return & 29.4 & 26.1 & -11.2 \\
Saturday & 100-cfm supply and return & 34.7 & 30.7 & -11.5 \\
Sunday & 100-cfm supply and return, & 42.9 & 34.5 & -19.6 \\
\hline
\end{tabular}




\section{DOE-2.2 Simulations}

A detailed simulation model was created using a beta version of the DOE-2.2 building energy simulation program. The initial simulation model was based on construction documents supplied by Watt Homes for Plan 4113. An audit of the two test houses proved to be valuable and led to a number of modifications to the simulation, mainly with regard to the attic construction and site shading.

Two DOE-2.2 models were created based on the alternative attic constructions observed in the field. The base-case model used a vented attic insulated at the ceiling level, with a natural ventilation rate of $1.5 \mathrm{ACH}$. The prototype model used an unvented attic, insulated between the roof joists, and constructed with no intentional ventilation to the outside. Simulations were run using actual test conditions to verify the accuracy of the models and using more realistic operating conditions to predict cooling energy savings after the houses were occupied.

The following sections describe the modeling considerations for the various building components.

\section{Wall and Floor Construction}

The walls were standard 2 x 4 construction, 16-in. on-center, with R-13 cellulose-filled cavities. The houses were built on slab foundations. Carpet pads were modeled during the test period and pads with carpet were modeled for the longer-term typical results. The windows were all constructed with low-e, spectrally selective glazing (PPG Sungate 1000), and vinyl frames. The solar heat gain coefficient (SHGC) for the glass was 0.37 and the window U-value was 0.35 $\mathrm{Btu} / \mathrm{hr} \bullet^{\circ} \mathrm{F} \bullet \mathrm{ft}^{2}$. Table 8 lists the total fenestration area for each orientation of the test houses.

\section{Table 8. Window Area by Orientation (includes framing)}

\begin{tabular}{cc}
\hline Orientation & Fenestration Area \\
\hline West & $45 \mathrm{ft}^{2}$ \\
South & $26 \mathrm{ft}^{2}$ \\
East & $14 \mathrm{ft}^{2}$ \\
North & $66 \mathrm{ft}^{2}$ \\
\hline
\end{tabular}

\section{Building Geometry and Shading}

The models included accurate building geometry to account for the effects of shading on windows and walls. Many of the windows were well shaded by adjacent houses. The DOE-2.2 model was imported into PowerDOE ${ }^{\circledR *}$ to check building geometry. Figure 17 shows the location of exterior walls, windows, doors, and overhangs as depicted in PowerDOE ${ }^{\circledR}$.

\footnotetext{
${ }^{*}$ PowerDOE is a graphic unser interface.
} 


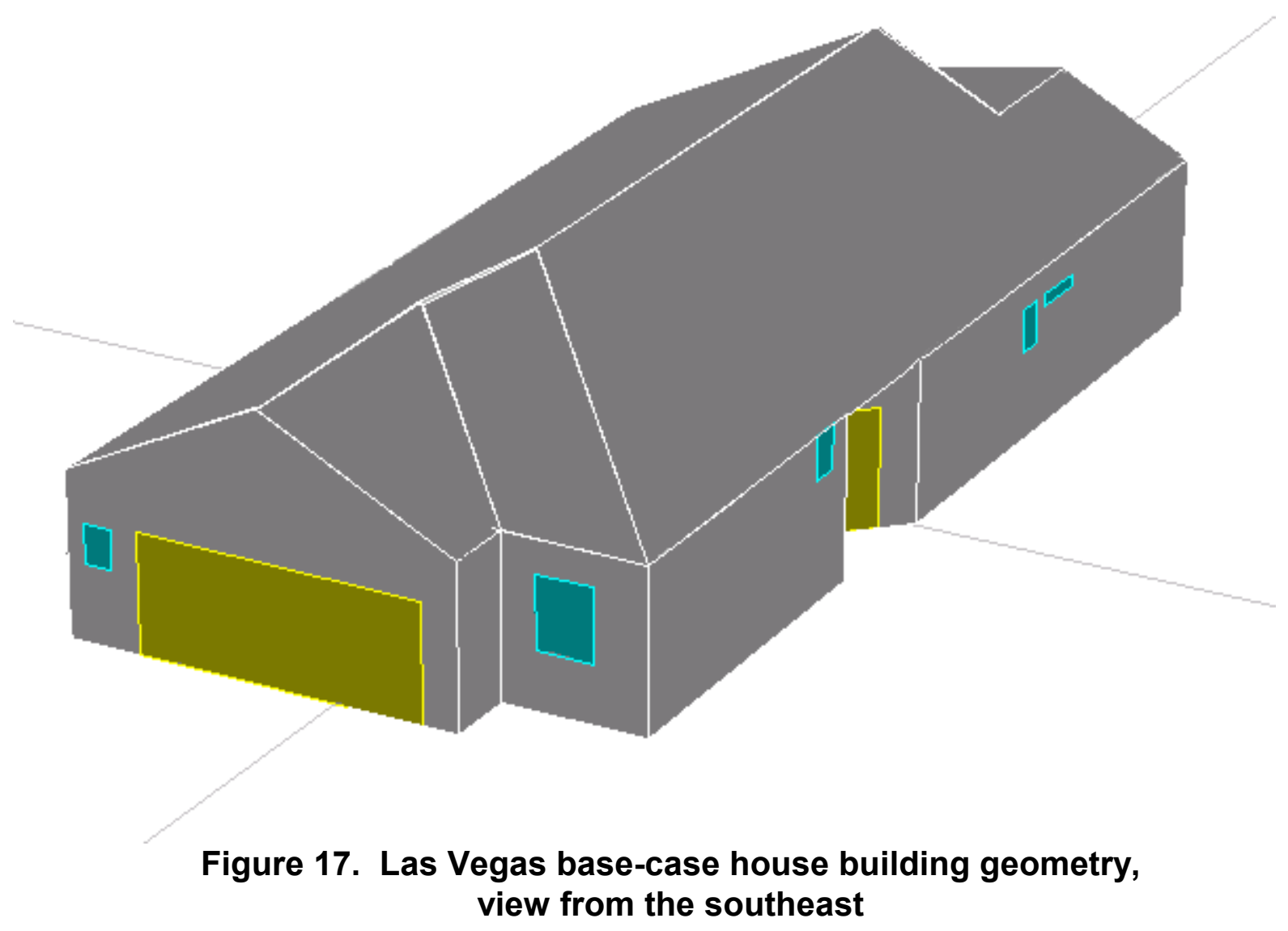

The geometry of the garage was slightly different between the two models. The vented attic was open to the area above the garage, while the unvented attic had an insulated wall between the attic and the garage.

Shading from adjacent houses was quite significant at this site, and an effort was made to accurately model these effects. Although the window area on the east and west sides of each house was small, the shading affected the total amount of heat transmitted though the opaque portions of the walls (Figure 18). The houses to the east and west were modeled as measured at the site. 


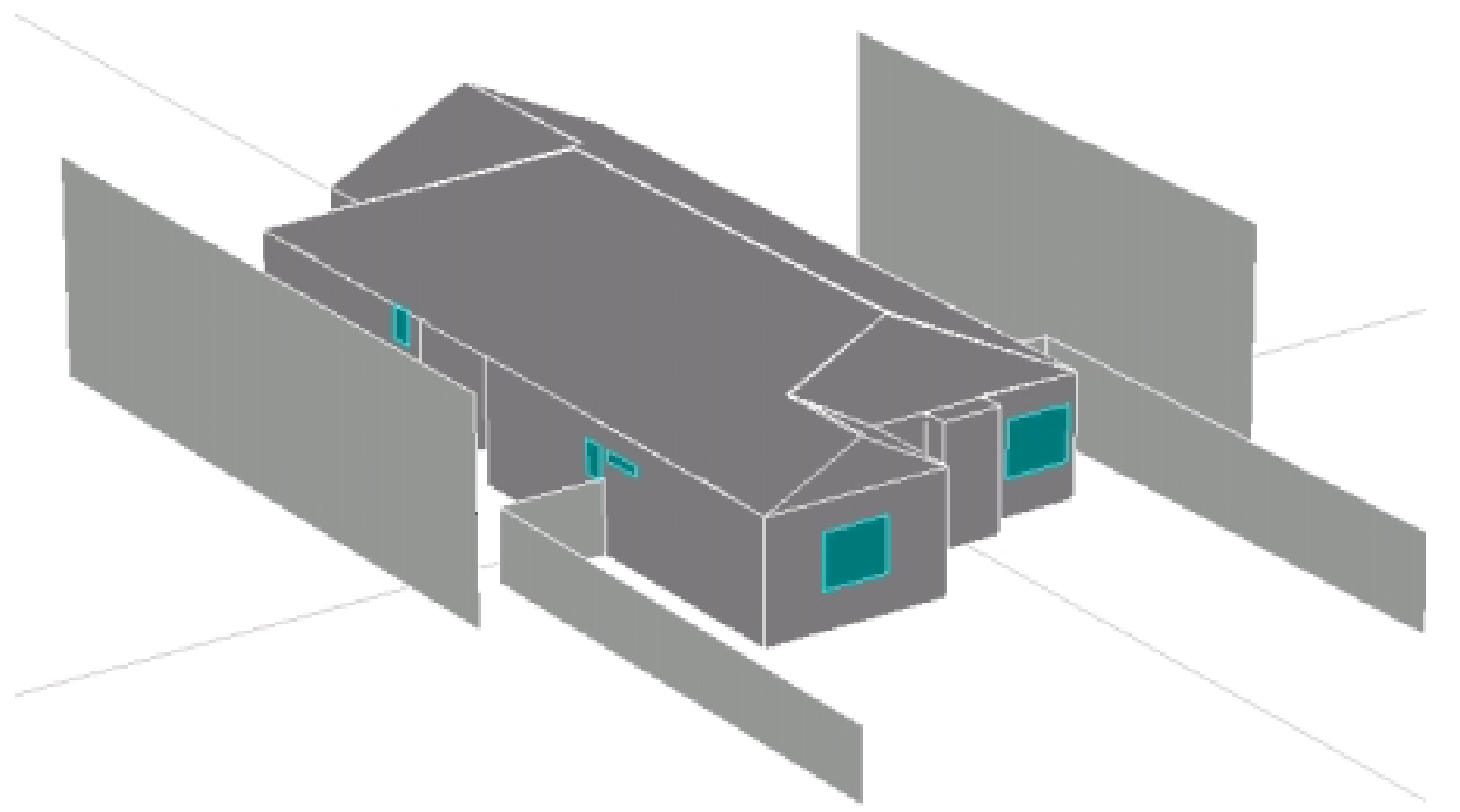

Figure 18. Building geometry of Las Vegas base-case house, view from the northeast, with shading from adjacent houses

\section{HVAC and Building Operation}

The building models were created with the capacity to simulate two different scenarios of building operation: testing conditions and typical conditions.

The testing conditions included a constant thermostat setpoint of $24^{\circ} \mathrm{C}\left(76^{\circ} \mathrm{F}\right)$, minimal internal gains from appliances and people, and no window management based on solar glare or solar gain (i.e., no opening and closing of shades). The existing 2.5-ton air-conditioning unit was modeled using the measured supply flow rates in each room, for a total supply flow rate of $1,050 \mathrm{cfm}$, including the supply duct loss in the attic.

The typical conditions were intended to represent average occupant behavior and lead to better predictions of annual energy use. Internal gains from people and appliances were included, and window management techniques were employed. Interior blinds were assumed for half the windows at all times, an approach that leads to roughly the same effect as using blinds randomly on all windows $50 \%$ of the time. Windows were also opened for intentional ventilation $50 \%$ of the time when outside air was below the thermostat setpoint and the thermostat called for cooling. 


\section{Air Infiltration}

The natural infiltration for both houses was relatively low, as measured during the field-testing. The outdoor airflow into the house was a combination of the natural infiltration and the outdoor airflow induced by the heating, ventilation, and air-conditioning (HVAC) system. A DOE-2.2 residential infiltration model was used along with the measured outdoor airflow rate induced when the HVAC system was on to simulate the total air infiltration of the house.

\section{Attic Model}

An accurate model of the attic was essential to capture the difference between the vented and unvented attic test houses. The modeling approach described earlier in this report was used for the analysis, with the following additions:

- Conductive losses from the supply ducts to the vented attic were set at $24 \mathrm{Btu} / \mathrm{hr} \bullet{ }^{\circ} \mathrm{F}$.

- One hundred percent of the supply duct leakage in the vented attic case was replaced by infiltration of outside or attic air into the conditioned space. The cooling energy of the supply air was not completely lost, however, because the leaks provide some cooling of the attic space.

- Because the vented attic and outdoor air were approximately the same temperature during the field test, a simple DOE-2.2 specification of "outdoor air" cfm was used for air induced into the house from either the outside or the attic. This assumption would not be appropriate during the winter months when the vented attic temperature is likely to be noticeably higher than the outdoor temperature or for houses with asphalt shingles instead of tile roofs.

\section{Test Conditions Simulation Results}

One of the objectives of the simulation effort was to predict the cooling energy requirements before the start of the field test. This information aided in designing an effective testing protocol. A cooling energy use profile was determined for a typical day in August, as shown in Figure 19, based on the initial description of the building, the cooling system (including part-load performance), and the attic design. 


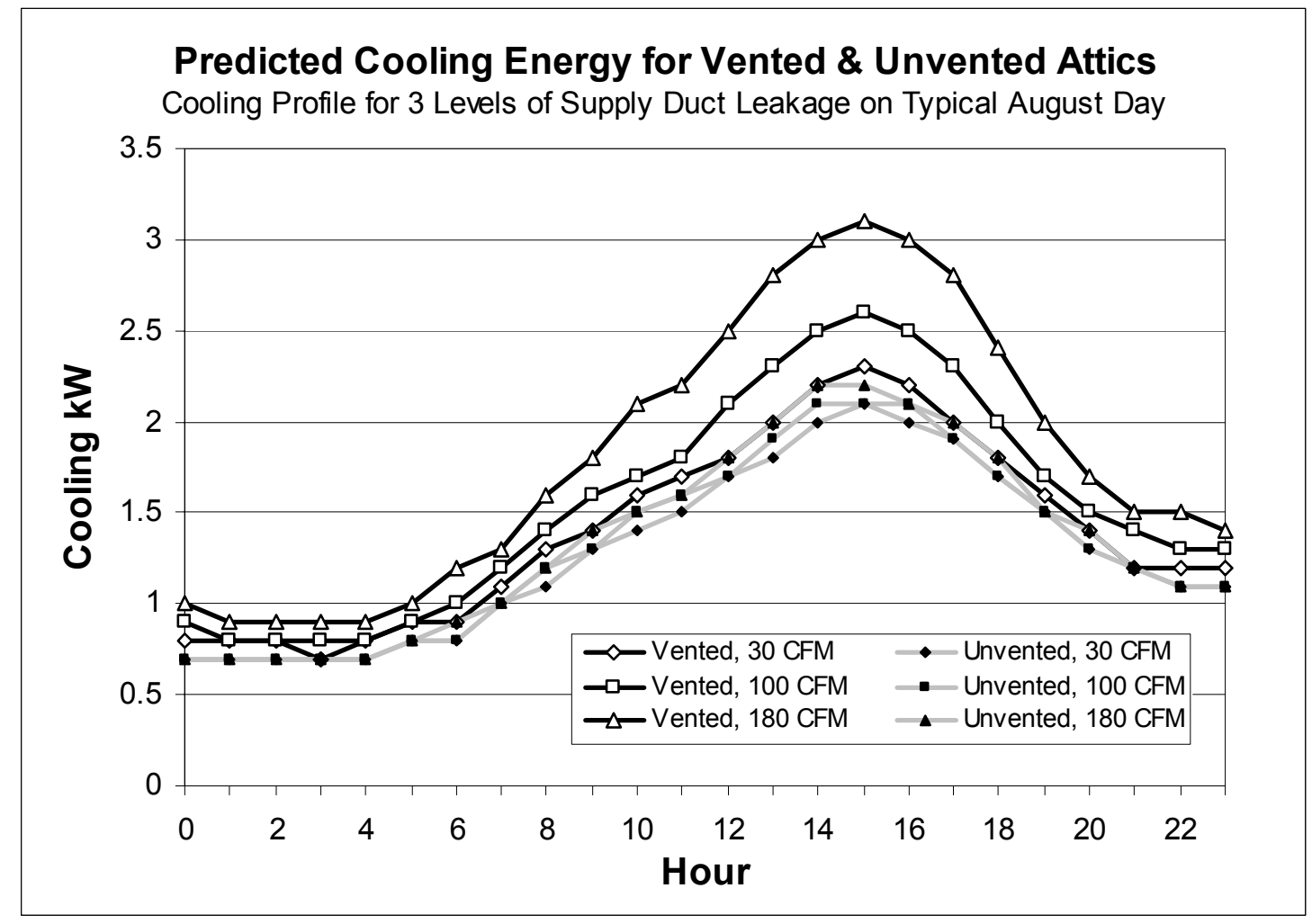

Figure 19. Pretest simulated cooling profile for Las Vegas test house with vented and unvented attics and varying levels of duct leakage. The unvented attic was insulated to R-22 and the vented attic to R-30

Based on these initial simulations, the following predictions were made regarding the two test houses:

- A measurable difference in cooling energy for the two houses was expected for medium to high levels of duct leakage.

- The unvented attic appeared to be insensitive to the amount of duct leakage.

- The cooling energy usage profile for the unvented attic appeared to be approximately the same as for the vented attic with low duct leakage.

Another goal of the simulation was to match the actual performance of the houses under a range of conditions. Figures 20-22 show the measured cooling energy use and the predicted cooling energy use for the two test houses during the test period. These graphs also include the measured outdoor temperature, which was the dominant independent variable for predicting the cooling energy use. Solar irradiance was not as strong an influence because both test houses had tile roofs. The data points plotted in the graphs are summarized in Table 9. 


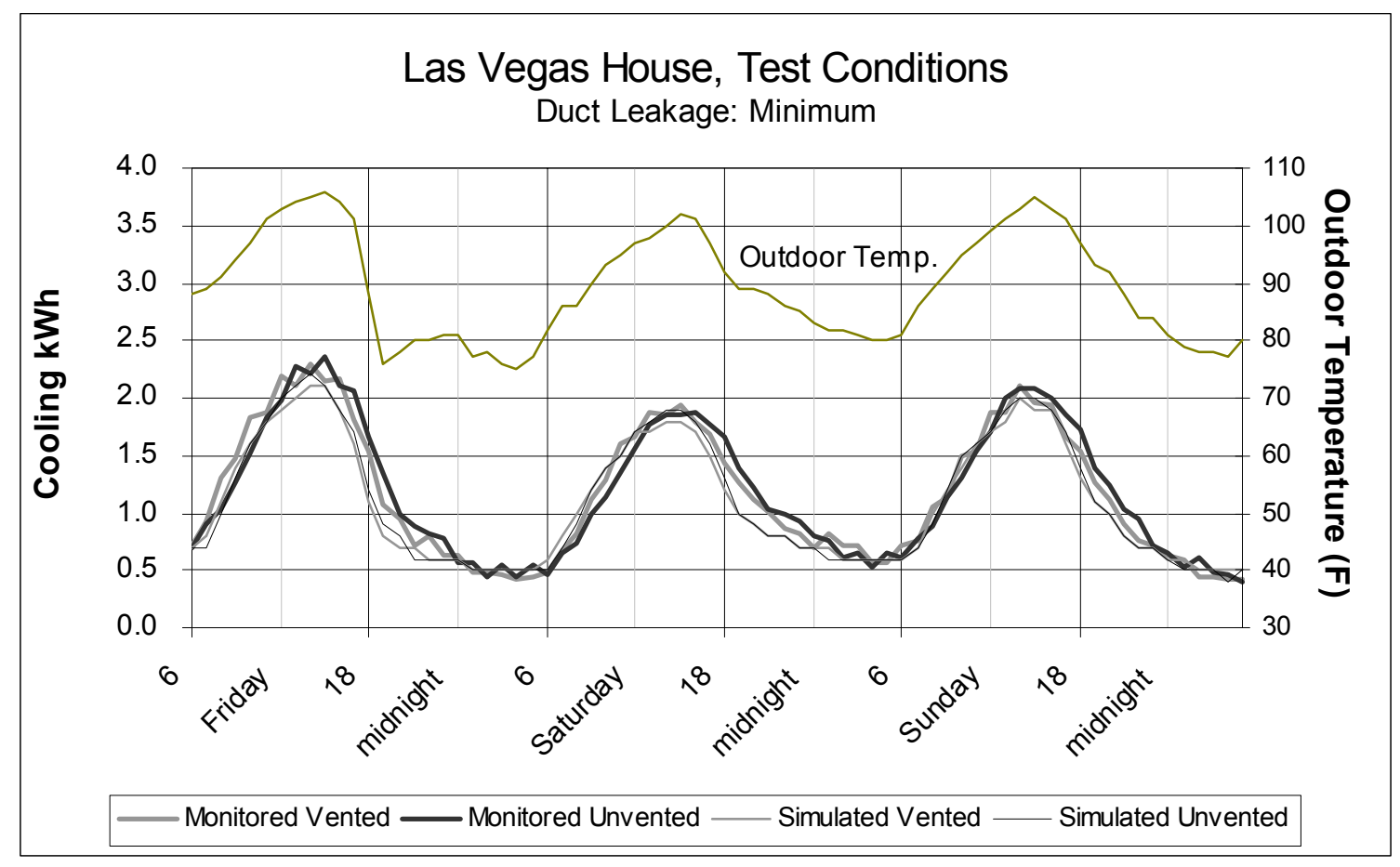

Figure 20. Monitored versus simulated cooling energy with tight ducts (Case 1)

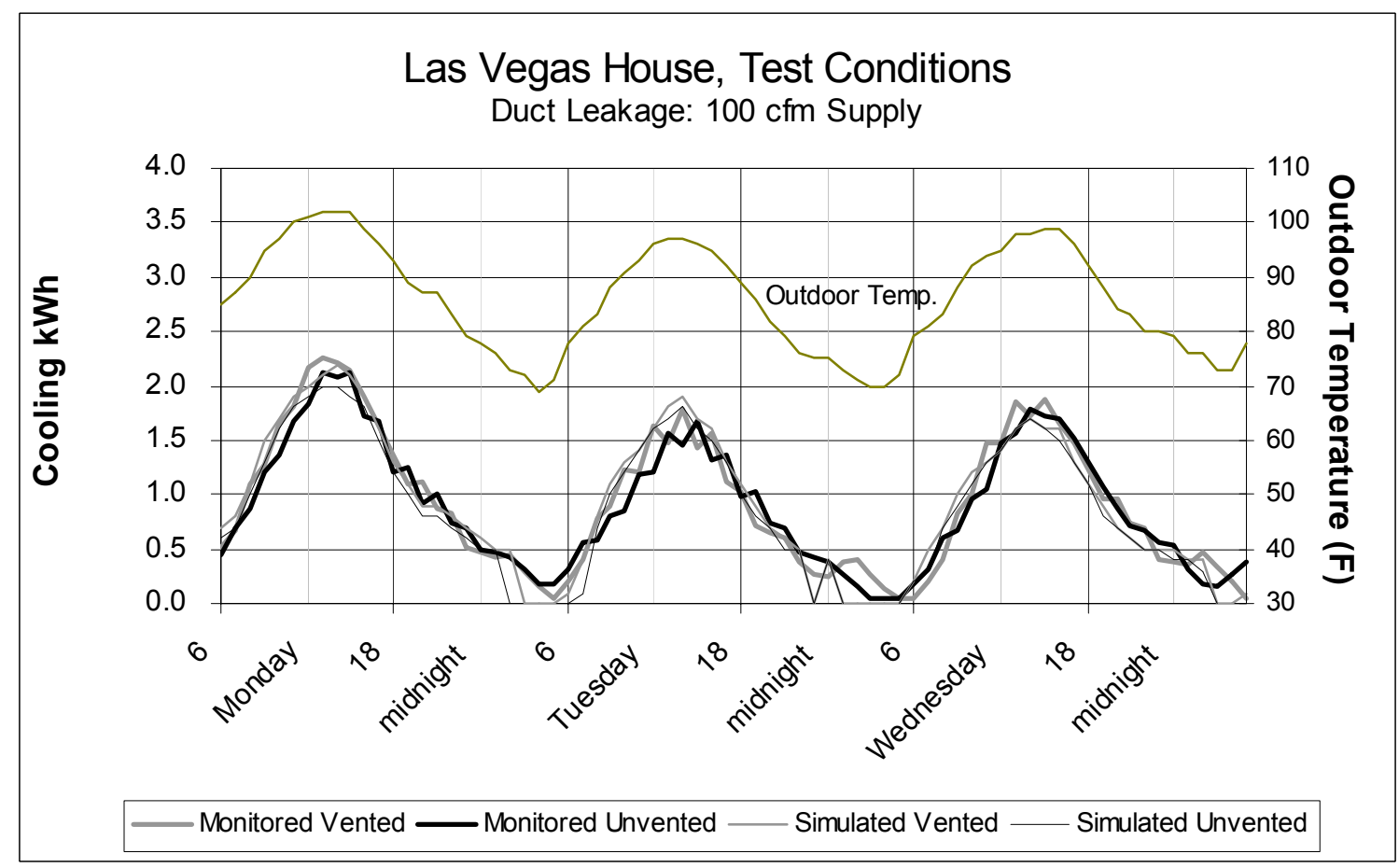

Figure 21. Monitored versus simulated cooling energy with 100-cfm supply duct leakage (Case 2) 


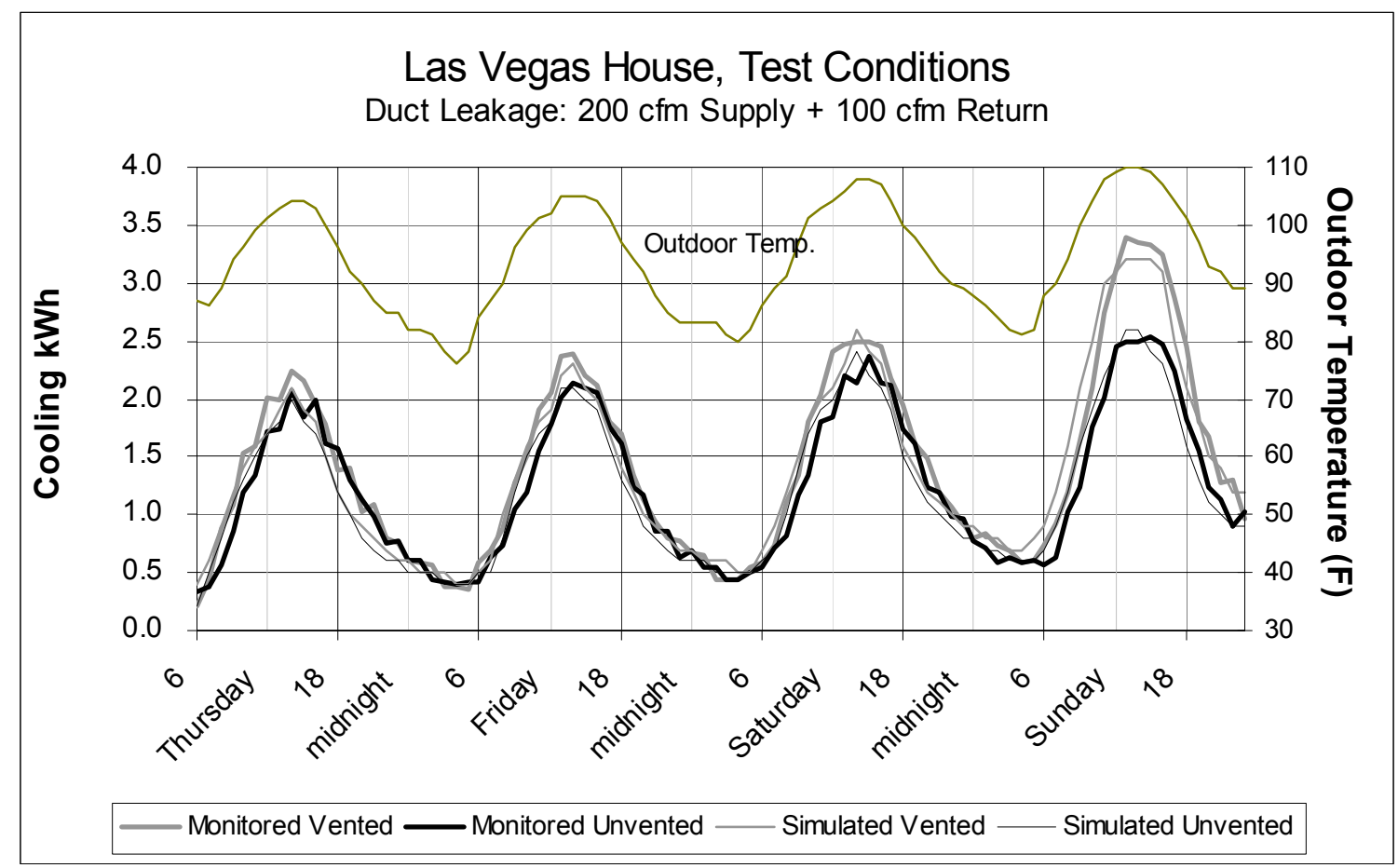

Figure 22. Monitored versus simulated cooling energy with $100-\mathrm{cfm}$ supply plus a 100 -cfm return duct leakage (Case 3, Thursday-Saturday) and an estimated 200cfm supply plus a 100-cfm return duct leakage (Case 4, Sunday)

Table 9. Comparison of Average Cooling Energy and Standard Deviation Based on Simulations and Field Measurements

\begin{tabular}{|c|c|c|c|c|c|c|c|c|}
\hline \multirow[t]{2}{*}{ Operating Conditions } & \multicolumn{2}{|c|}{$\begin{array}{c}\text { Case 1: Tight } \\
\text { Ducts }\end{array}$} & \multicolumn{2}{|c|}{$\begin{array}{l}\text { Case 2: } 100-c f m \\
\text { Supply Leak }\end{array}$} & \multicolumn{2}{|c|}{$\begin{array}{c}\text { Case 3: } 100-\mathrm{cfm} \\
\text { Supply and } \\
\text { Return Leaks }\end{array}$} & \multicolumn{2}{|c|}{$\begin{array}{c}\text { Case 4: } \\
\text { Additional } \\
\text { Supply Leakage }\end{array}$} \\
\hline & Base & Proto & Base & Proto & Base & Proto & Base & Proto \\
\hline $\begin{array}{l}\text { Monitored Average } \\
\text { Cooling Energy }(\mathrm{kW})\end{array}$ & 1.17 & 1.18 & 0.93 & 0.89 & 1.26 & 1.14 & 2.20 & 1.71 \\
\hline $\begin{array}{l}\text { Simulated Average } \\
\text { Cooling Energy }(\mathrm{kW})\end{array}$ & 1.09 & 1.10 & 0.92 & 0.85 & 1.21 & 1.11 & 2.23 & 1.70 \\
\hline $\begin{array}{l}\text { Monitored Standard } \\
\text { Deviation }(\mathrm{kW})\end{array}$ & 0.57 & 0.57 & 0.63 & 0.57 & 0.68 & 0.60 & 0.92 & 0.66 \\
\hline $\begin{array}{l}\text { Simulated Standard } \\
\text { Deviation }(\mathrm{kW})\end{array}$ & 0.52 & 0.55 & 0.65 & 0.63 & 0.61 & 0.59 & 0.79 & 0.64 \\
\hline
\end{tabular}


The graphs demonstrate that the measured peak cooling energy use and daily cooling energy profiles were closely matched by the simulation results throughout the test period. It can also be seen from the graphs and the summary table that the model responded accurately to changes in the cooling load and changes in the amount of duct leakage. Both the simulation and the field test indicated that there was very little difference in cooling energy use between the vented and unvented attics when the ducts were very tight. However, both peak and average cooling energy for the unvented attic was about $20 \%$ less than it was for the vented attic on the final day of testing, when the ducts were extremely leaky and the outside temperature was the hottest.

\section{Simulation Results for Full Summer}

The simulation models were used with typical summer weather conditions to predict the annual cooling energy requirements using a variety of duct leakage characteristics. In addition to the differences in attic ventilation, these simulations assumed R-22 insulation at the roof plane for the unvented attic and R-30 at the ceiling plane for the vented attic. These measures were treated as a package for the purpose of this analysis, but clearly the unvented attic would perform better if R-30 insulation were used at the roof plane. (See Appendix for a sensitivity study based on a Tucson prototype.) Figure 23 shows the monthly cooling energy for the vented and unvented attic houses with low $(30 \mathrm{cfm})$ supply duct leakage and high $(200 \mathrm{cfm})$ supply duct leakage. Cooling energy was highest in the case of a vented attic with high duct leakage. The other three cases had approximately the same monthly cooling profile.

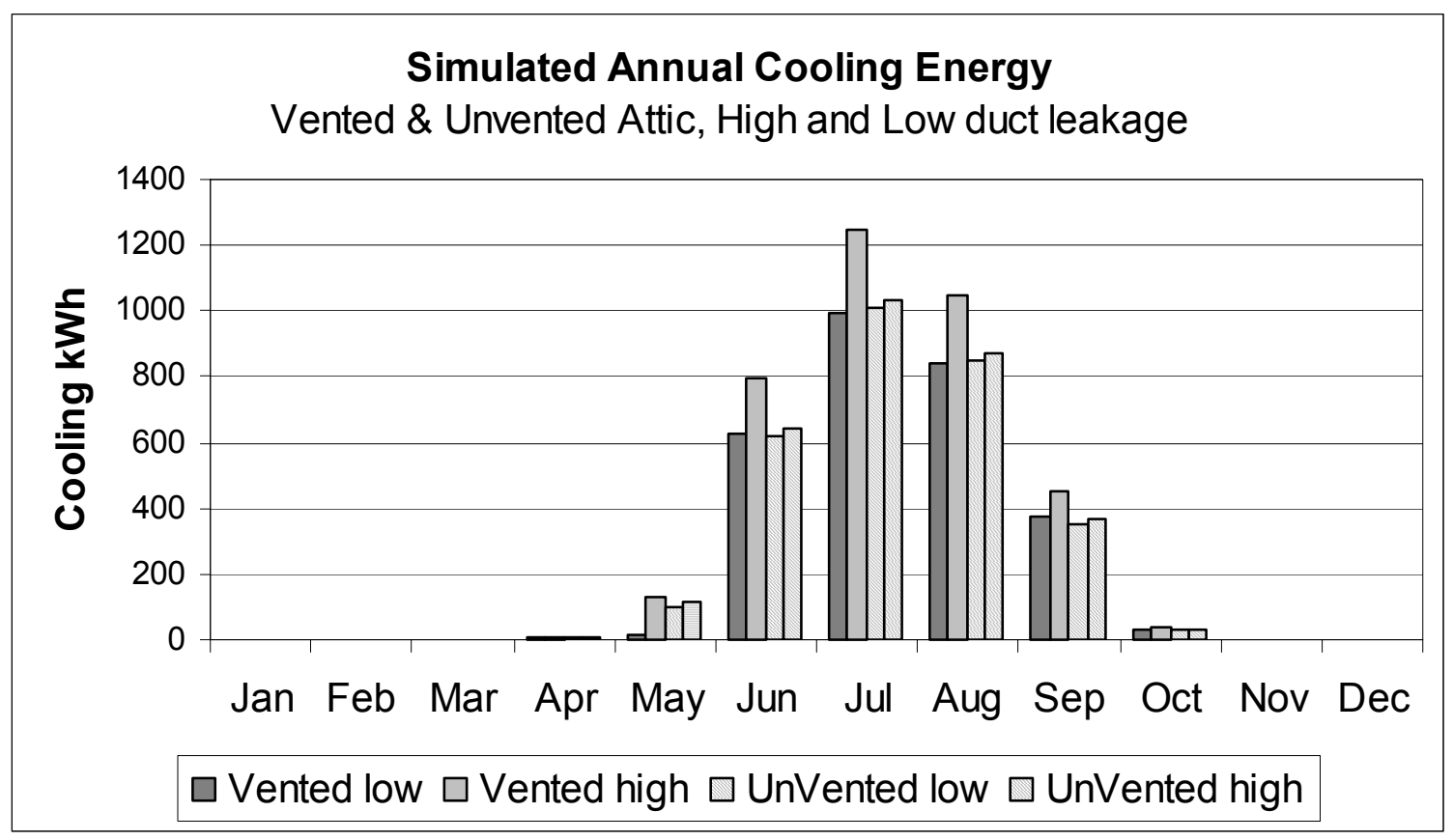

Figure 23. Predicted monthly cooling energy for Las Vegas test house with vented attic insulated to $R-30$ at the ceiling plane and unvented attic insulated to $\mathrm{R}-22$ at the roof plane 
Figure 24 shows the estimated annual cooling requirement over a range of duct losses. Below 50 cfm of supply leakage, the annual cooling energy was very similar for both attic types. With 100 cfm of supply duct leakage, annual energy use for the house with the vented attic was predicted to be approximately $8 \%$ more than for the house with the unvented attic. At $200 \mathrm{cfm}$ of supply duct leakage, the difference increased to about $20 \%$.

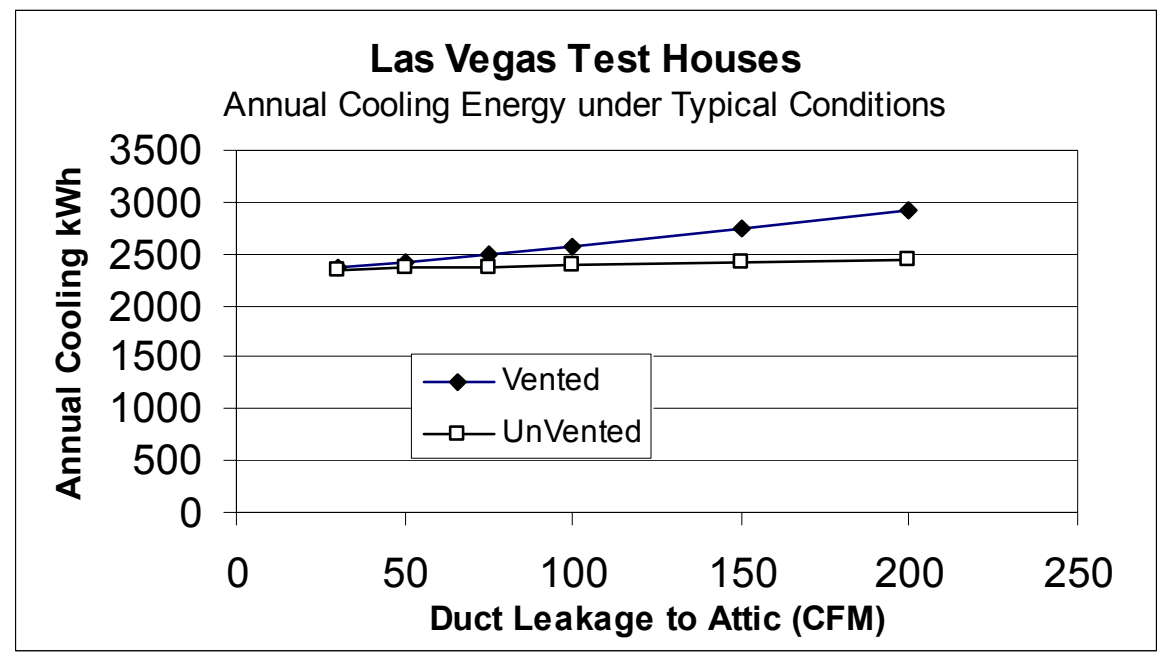

\section{Figure 24. Annual cooling requirement versus duct leakage for Las Vegas test houses}

\section{Key Findings}

Based on the summertime field monitoring of the two test houses and the DOE-2.2 models, the following conclusions were drawn:

- The cooling requirement for the unvented attic house was fairly insensitive to the amount of supply and return duct leakage.

- At low duct leakage levels, the houses with vented and unvented attics had very nearly the same annual cooling energy requirement based on the DOE-2.2 simulation. For supply duct leakage greater than $5 \%$ of total flow $(\sim 50 \mathrm{cfm})$, the unvented attic house would require noticeably less annual cooling energy.

- The cooling requirements for the two houses were well characterized by the calibrated DOE-2.2 model. The simulation models were able to accurately predict the cooling energy use for the vented and unvented attic houses over a wide range of duct leakage and outdoor weather conditions.

- The unvented attic temperature remained within $7^{\circ} \mathrm{F}$ of the inside temperature throughout the summer test period. The vented attic temperature essentially tracked the outside temperature during the same period. 


\section{Case 2: Tucson, Arizona}

Two additional houses were tested by NREL in two Building America communities built by Pulte Homes in Tucson, Arizona. The tests were conducted in late August 1999. One house was a Building America prototype and featured an unvented attic with R-22 netted cellulose insulation under a sloped roof deck. The other house, referred to as the base case, had a flat roof and R-30 fiberglass batts at the ceiling plane. The prototype had several other design features that were different from the base case, including a downsized air conditioner, lower ceiling height, less floor area, south-facing orientation, low-e windows, continuous exhaust ventilation, and a high-efficiency furnace. Because these differences made it very difficult to isolate the effects of the unvented attic based on testing alone, it was necessary to use modeling to evaluate the energy use of the prototype house with an unvented attic compared to a similar base case with a vented attic. Key specifications for both houses are presented in Table 10, but the test results for the base case are not discussed in this report because its unusual flat attic design does not provide a reasonable basis for comparison with the prototype. Photos of the front and back of the prototype house are shown in Figure 25. 
Table 10. Tucson Test House Descriptions

\begin{tabular}{|c|c|c|c|}
\hline \multirow{4}{*}{\multicolumn{2}{|c|}{ Location }} & Base case & Prototype \\
\hline & & Reflections at the Bluffs, Lot 445 & Retreat at the Bluffs, Lot 580 \\
\hline & & 8919 N. Treasure Mountain Dr. & 9093 Sweet Acacia Place \\
\hline & & Tucson, Arizona & Tucson, Arizona \\
\hline \multicolumn{2}{|l|}{ Model } & $\begin{array}{l}\text { \#5001, Marsanne, } 1 \text {-story, } 3 \\
\text { bedrooms, } 2 \text { baths }\end{array}$ & $\begin{array}{l}\text { \#1618, The Preserve, 1-story, } 4 \\
\text { bedrooms, } 2 \text { baths }\end{array}$ \\
\hline \multicolumn{2}{|l|}{ Size $\left(\mathrm{ft}^{2}\right)$} & 1,629 & 1,618 \\
\hline \multicolumn{2}{|l|}{ Options } & Flat roof with $10-\mathrm{ft}$ ceilings & $\begin{array}{l}\text { Sloped roof, elevation A, patio } \\
\text { cover, bay window @ MBR }\end{array}$ \\
\hline \multicolumn{2}{|c|}{ Front orientation } & East & South \\
\hline \multirow[t]{4}{*}{ Insulation } & - Walls & $\begin{array}{l}\text { R-19 fiberglass batts, } 2 \times 6,16 \text {-in. } \\
\text { oc }{ }^{\dagger}, \text { R-4 EPS sheathing }\end{array}$ & $\begin{array}{l}\text { R-19 cellulose, } 2 \times 6,24 \text {-in. oc, } \\
\text { R-4 EPS sheathing }\end{array}$ \\
\hline & - Roof & $\begin{array}{l}\text { R-30 fiberglass at ceiling, small } \\
\text { amount of venting }\end{array}$ & $\begin{array}{l}\text { R-22 cellulose under roof deck, } \\
\text { unvented }\end{array}$ \\
\hline & & Uninsulated, carpet installed & Same, carpet pad only \\
\hline & - Slab & & \\
\hline \multicolumn{2}{|l|}{ Windows } & $\begin{array}{l}\text { Double-pane, vinyl frame, clear } \\
\text { glazing, } \mathrm{U}=0.46, \mathrm{SHGC}=0.57\end{array}$ & $\begin{array}{l}\text { Double-pane, vinyl frame, } P P G \\
\text { Sungate } 1000, \mathrm{U}=0.35 \\
\mathrm{SHGC}=0.37\end{array}$ \\
\hline \multicolumn{2}{|c|}{ Exterior Finish } & $\begin{array}{l}\text { Membrane roof covering, stucco } \\
\text { siding }\end{array}$ & Tile roof, stucco siding \\
\hline \multicolumn{2}{|c|}{ Ventilation } & None & $\begin{array}{l}\text { Continuous exhaust fan in utility } \\
\text { room, rated } 80 \mathrm{cfm}\end{array}$ \\
\hline \multicolumn{2}{|l|}{ Ducts } & $\begin{array}{l}\text { Air handler in garage, supply and } \\
\text { return ducts in attic }\end{array}$ & $\begin{array}{l}\text { Air handler in unvented attic, } \\
\text { ducts in unvented attic }\end{array}$ \\
\hline \multicolumn{2}{|l|}{ Cooling } & 4.0 tons, 12-SEER (Carrier) & $\begin{array}{l}2.0 \text { tons, } 12 \text {-SEER, downsized } \\
\text { to } 80 \% \text { of Manual J guidelines }\end{array}$ \\
\hline \multicolumn{2}{|l|}{ Heating } & $\begin{array}{l}\text { Gas furnace, natural venting, } 80 \% \\
\text { AFUE }\end{array}$ & $\begin{array}{l}\text { Gas furnace, direct venting, } \\
\text { 92.6\% AFUE }\end{array}$ \\
\hline \multicolumn{2}{|l|}{ Zoning } & 1 thermostat, single-zone control & Same \\
\hline \multicolumn{2}{|c|}{ Water Heating } & 40-gallon tank in garage, $0.54 \mathrm{EF}$ & $\begin{array}{l}\text { 40-gallon tank (Rheem) in } \\
\text { garage, } 0.62 \mathrm{EF} / 0.76 \mathrm{RE}^{\ddagger}\end{array}$ \\
\hline
\end{tabular}

\footnotetext{
${ }^{*}$ Master bedroom

${ }^{\dagger}$ on-center

${ }^{\ddagger}$ Recovery efficiency
} 

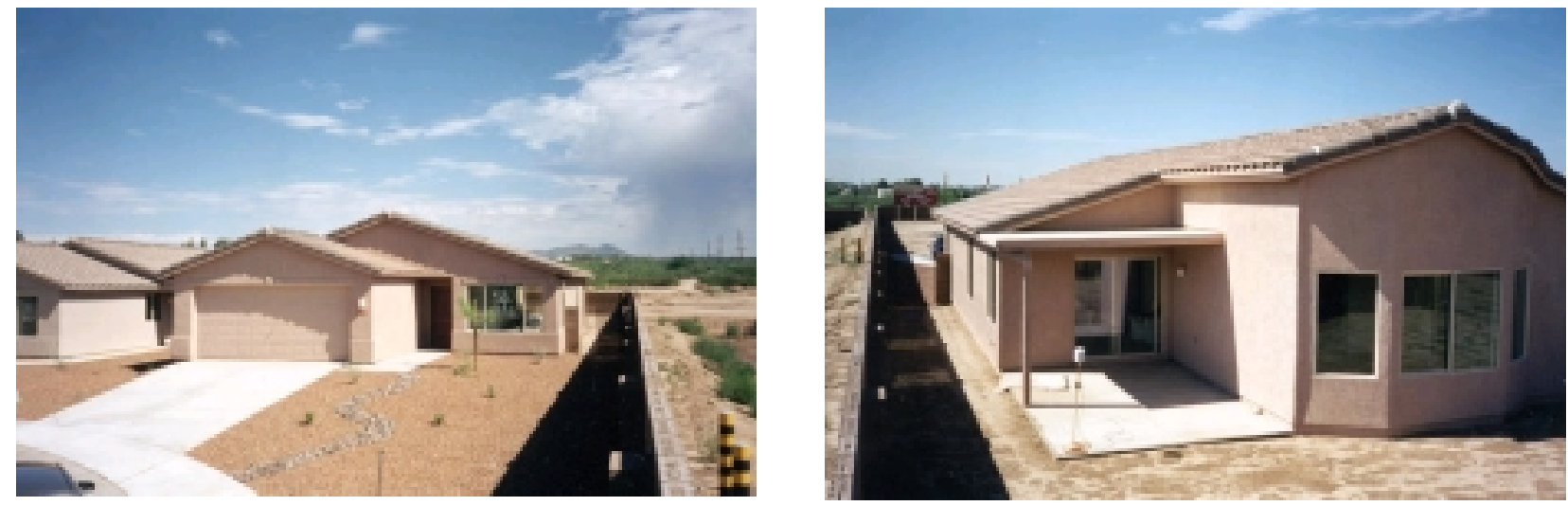

Figure 25. Front and rear views of Tucson prototype house

The two houses were operated for 3 consecutive days with constant thermostat setpoints from the morning of August 23 until the morning of August 26, representing normal operation under typical summer conditions. The ventilation fan in the prototype house was not operated during this test period. Average temperature and wind conditions during this period are shown in Figures 26 and 27. Two severe early evening thunderstorms account for the rise in average wind speed from about 7:00 p.m. to 10:00 p.m.

The temperature of the unvented attic was usually about midway between the outside air temperature and the conditioned interior of the house, as shown in Figure 26. Clearly the air ducts were exposed to milder summer temperatures in the unvented attic than they would have been in a typical vented attic. However, it would be incorrect to view the attic space as "conditioned space," because any conditioned air supplied to the attic resulted from unintentional duct leakage. 


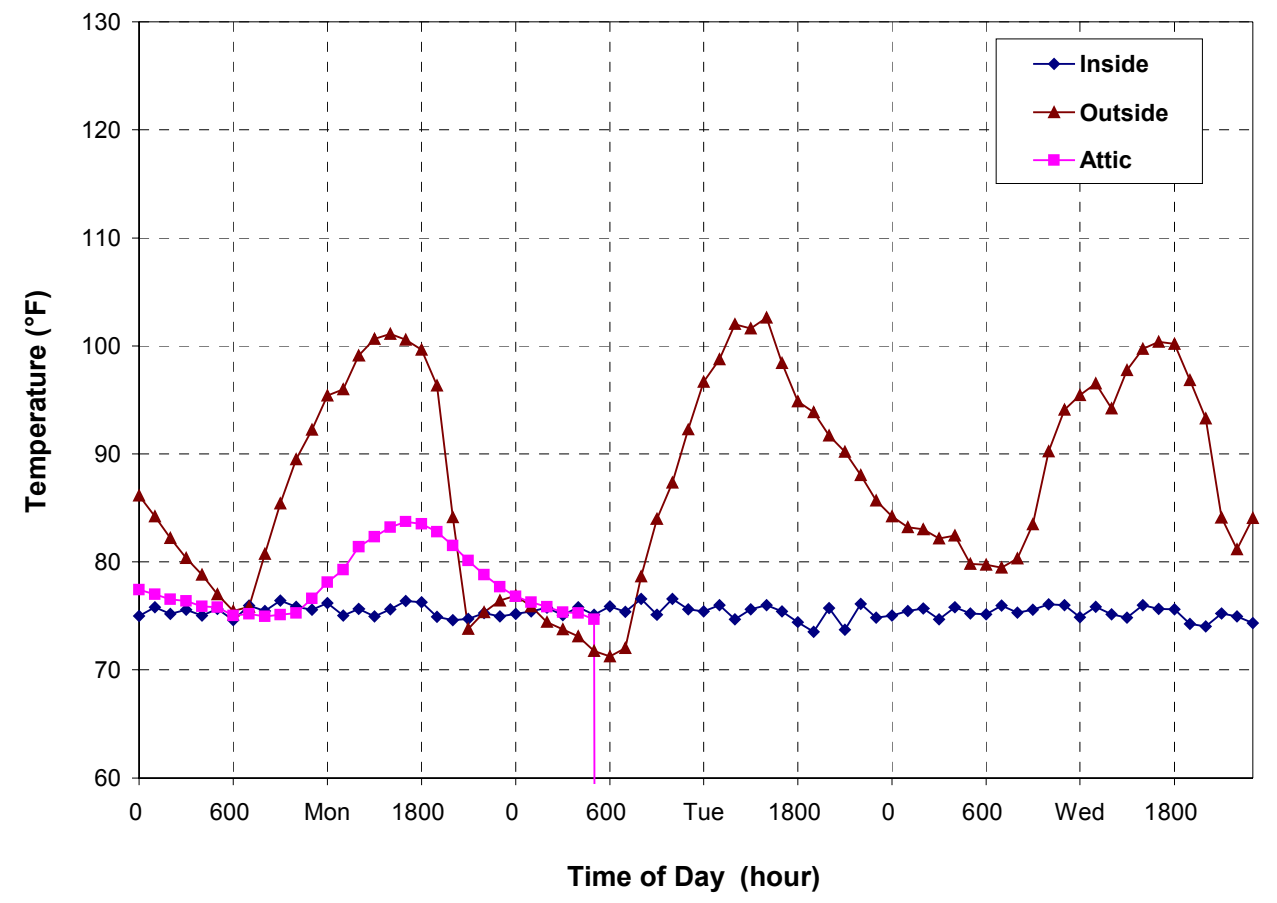

Figure 26. Inside and outside temperatures for Tucson prototype during a 3-day period of normal air conditioner operation. The attic temperature was only monitored for the first day

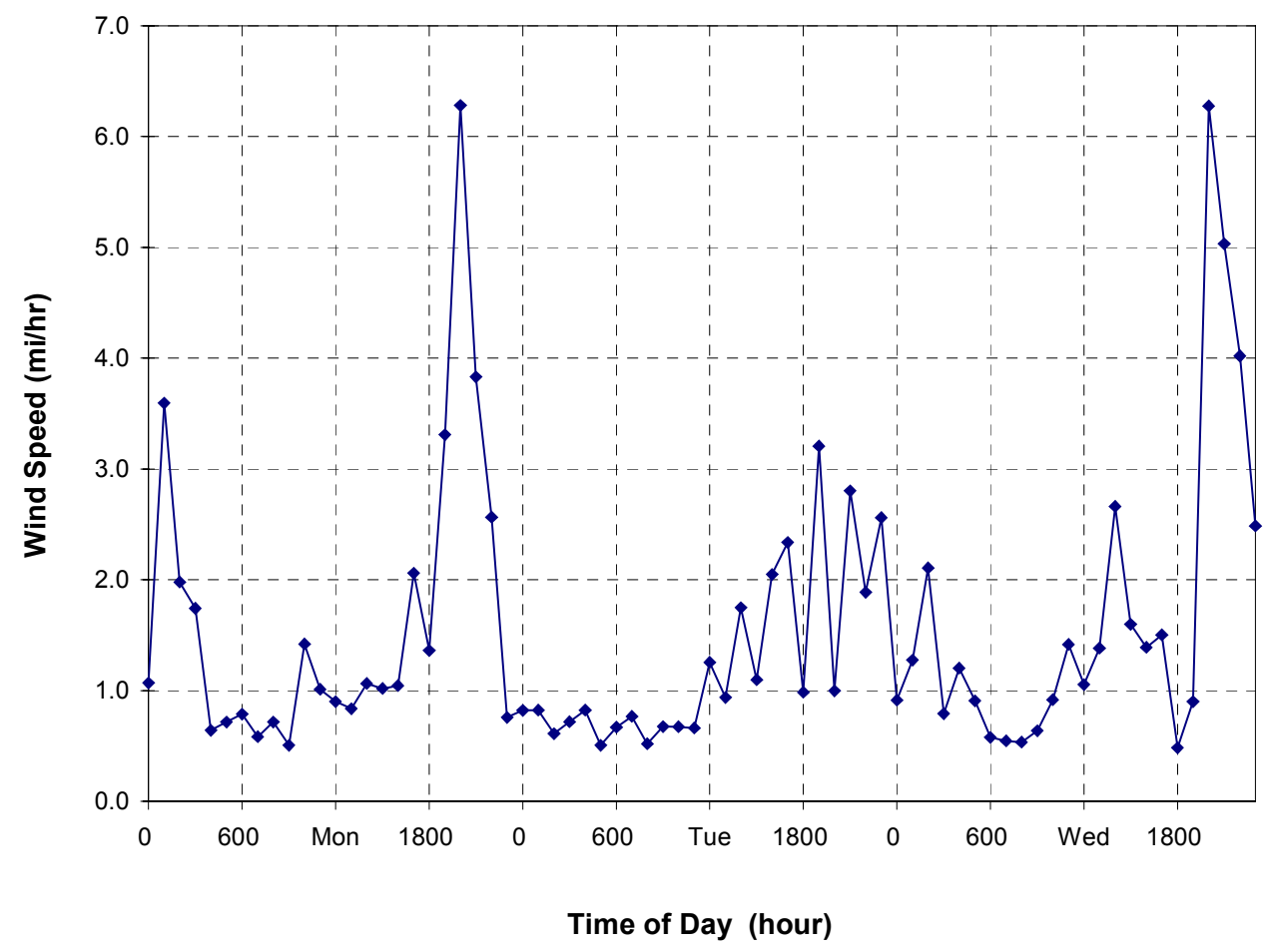

Figure 27. Wind speed near Tucson prototype during a 3-day period of normal operation 
Figure 28 shows the measured air-exchange rate for the prototype house during the normal operation test period. It is important to note that tracer gas was injected in the living space and not in the attic, although mixing with the attic was expected. The air change rate for the house was relatively low, rarely exceeding $0.20 \mathrm{ACH}$. The ACH does not appear to increase significantly during periods of nearly continuous air-handler operation in the late afternoon, even though the driving forces of wind and temperature difference are also higher during this period. These results indicate that the amount of additional air exchange induced by air handler operation was relatively small for the prototype house (approximately $10-15 \mathrm{cfm}$ ), supporting the notion that the unvented attic in the prototype was well sealed. However, blower door tests conducted by BSC indicated that the total ACH of the house increased about $50 \%$ when the attic hatch was open. This result demonstrated that a significant amount of air leakage occurred at the roof plane, and there was some restriction of air exchange between the attic and the rest of the house. It is, therefore, apparent that the ducts themselves must have been very tight.

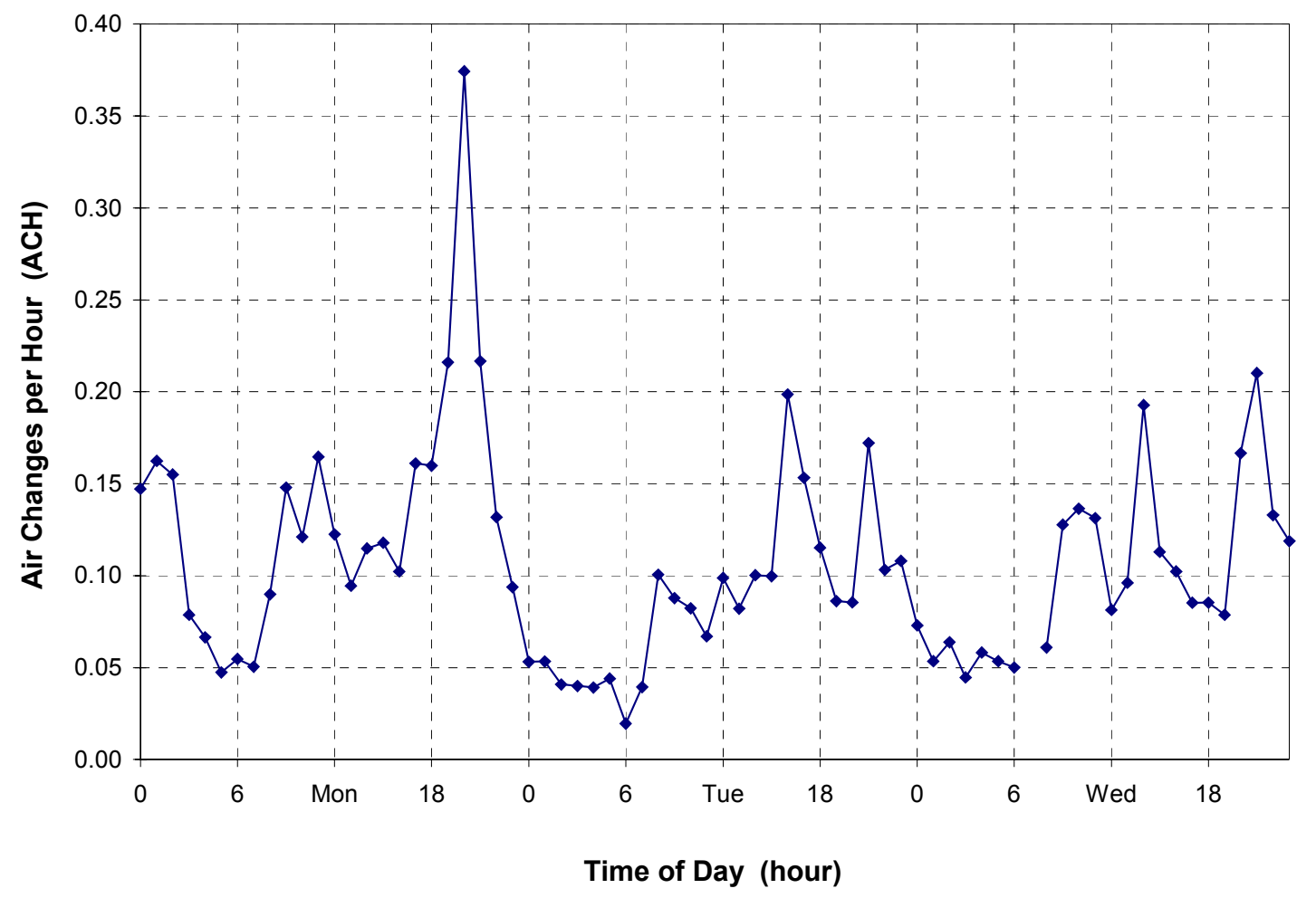

Figure 28. Air-exchange rate for Tucson prototype during a 3-day period of normal operation 
Duct blaster testing conducted by BSC in 1999 did not seem to support the conclusion that the ducts were especially tight. Duct blaster testing of the prototype house by BSC on August 19, 1999 , resulted in a total leakage measurement of $168 \mathrm{cfm}$ at $25 \mathrm{~Pa}$, which was about $23 \%$ of the total supply flow rate. Of this total, about $60 \mathrm{cfm}$, or $36 \%$ of the duct leakage, was to the outside when the attic hatch was closed and about $13 \mathrm{cfm}$ was to the outside when the hatch was open. Aside from predicting higher duct leakage than was measured by the tracer gas, these tests also suggested that the attic was not very well connected to the interior of the house from an airexchange standpoint. Pulte Homes repeated the test on August 25, 1999, after improvements were made to the duct-sealing process, and the total leakage for the prototype was reduced to 117 $\mathrm{cfm}$, or $16 \%$ of total flow. When interpreting duct blaster results, however, it is very important to remember that ducts pressurized to $25 \mathrm{~Pa}$ behave very differently than ducts under normal air handler operation. Internal pressure gradients and interactions with the rest of the house are minimized during duct blaster measurements. Tracer gas testing is, therefore, a more accurate approach to estimating the air exchange caused by operation of the air distribution system.

A DOE-2.2 model was developed to simulate annual energy usage for the prototype house with and without various design attributes, including the unvented attic. To the extent possible, field measurements were used as inputs to the model to ensure realism. Figures 29 and 30 show the building envelope as modeled in PowerDOE.

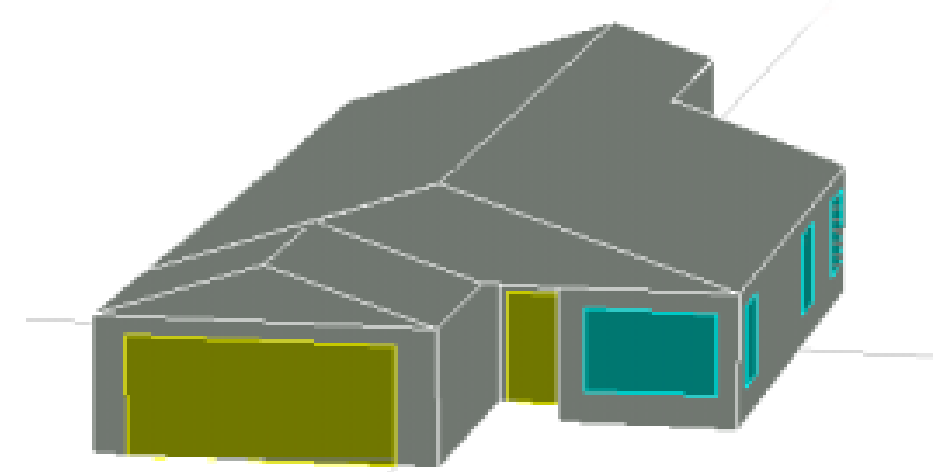

Figure 29. Front of prototype house (shading not included) (Image captured from PowerDOE)

\footnotetext{
${ }^{*}$ A measurement uncertainty of about $5 \%$ is expected when a duct blaster is used in accordance with accepted practice.
} 


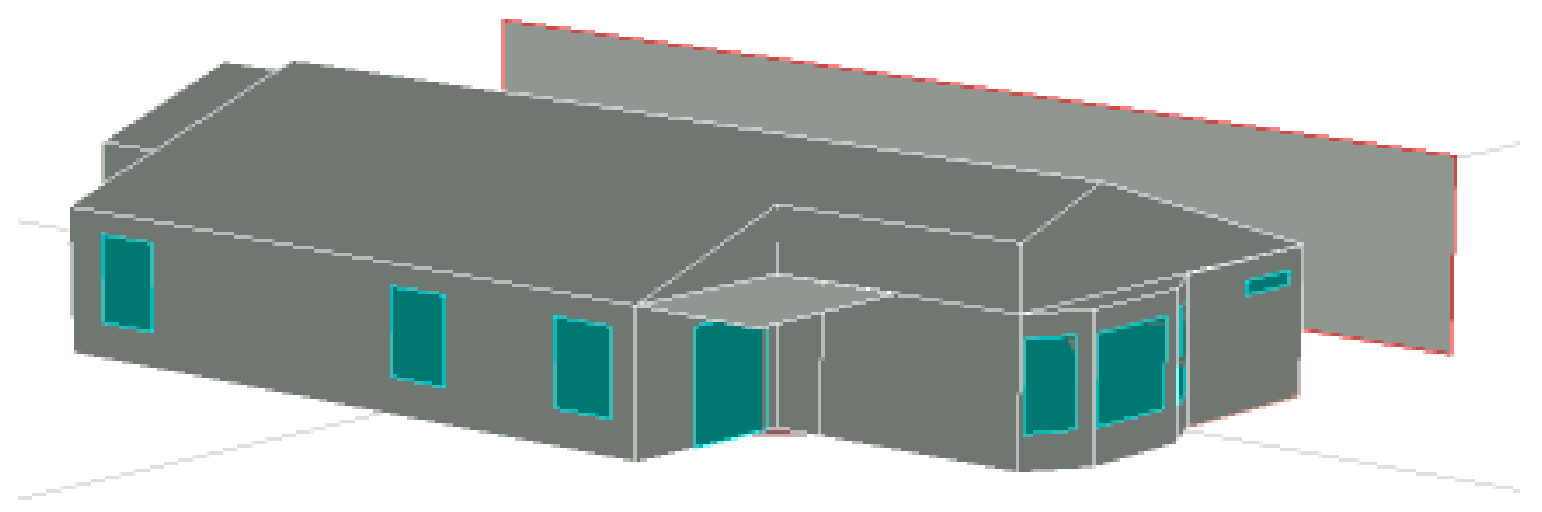

Figure 30. Side and back of prototype house, including porch and nearby shading (Image captured from PowerDOE)

The analysis started with the geometry of the prototype house, but with energy-related specifications consistent with builder standard practice. Features were then incrementally added until the prototype house was simulated. Test data were used to establish many of the inputs to the models, such as infiltration rates, air handler flow rate and power, and duct leakage. The models were then modified to better capture typical occupant behavior and house operation over a full year.

Features common to all of the building simulations:

- Shading from nearby building and patio shading (see Figure 30)

- Use of interior blinds and draperies:

- Half of all windows were assumed to be covered at all times

- When shades or draperies were used, the window R-value was increased by 1.0

- When shades or draperies were used, the shading coefficient was reduced by $40 \%$

- Supply flow rate of $350 \mathrm{cfm}$ per ton of cooling. This was the average of the measured data

- Natural infiltration coefficients calculated based on tracer gas measurements. The residential infiltration model in DOE-2.2 was used. This is a multiple linear-regression model that estimates the hourly infiltration rate based on a constant, a wind-driven component, and a component driven by temperature difference. Infiltration induced by system fan operation and by intentional venting was included separately. 
The approach to modeling the vented and unvented attics included the following assumptions:

- The duct thermal conductance (UA) was calculated using R-5 duct insulation

- For the vented attic, $80 \%$ of the supply duct leakage was assumed to be lost to the outside. This assumption was derived from a combination of engineering judgment and the process of reconciling the simulated results with field measurements

- For the unvented attic, it was assumed that $25 \%$ of the supply air leakage was lost immediately to the outside, and replaced with outside air added directly to the return airstream. The other $75 \%$ was assumed to mix with the attic air. This assumption was also based on both engineering judgment and calibration of the simulated results with field measurements.

At the time the analysis described in this report was performed, DOE- 2.2 could not directly model the affect of return duct leakage. An equivalent heat transfer was approximated using an air wall between the attic and the main house space in addition to the normal ceiling, with a total UA equivalent to the heat capacity of the return air leak. The result was an additional load on the heating or cooling system equal to the amount of energy necessary to raise or lower the temperature of the return air leak from the attic temperature to that of the conditioned space. The area of the air wall was defined as:

$$
\text { Area }=\rho \cdot \mathrm{C}_{\mathrm{p}} \bullet(60 \mathrm{~min} / \mathrm{hr}) \cdot \mathrm{CFM}_{\text {ret }} / \mathrm{U}_{\text {airwall }},
$$

where

$\mathrm{U}_{\text {airwall }}=$ any arbitrary thermal conductivity $\left(\mathrm{Btu} / \mathrm{hr} \cdot \mathrm{ft}^{2} \cdot{ }^{\circ} \mathrm{F}\right)$ that results in a reasonable value for area

$\mathrm{CFM}_{\text {ret }}=$ the return air leakage to the outside (cfm) as measured using a duct blaster

$$
\rho \cdot \mathrm{C}_{\mathrm{p}}=0.018 \mathrm{Btu} / \mathrm{ft}^{3} \cdot{ }^{\circ} \mathrm{F} \text {. }
$$

Table 11 presents a summary of modeling results for a series of simulations. This series started with the builder standard practice building description, and then measures were added one at a time until the building matched the prototype specifications. A number of issues were considered when determining the order in which the measures would be added to the building model. First, the local builder was also building a number of houses that met ENERGY STAR ${ }^{\circledR}$ requirements, including the base-case house that was tested at Reflections at the Bluffs. These houses had 2-in. x 6-in. walls, vinyl-frame windows, and SEER 12 air-conditioning units. These measures were added first so that a comparison of the prototype house with the base-case house could be made. From the ENERGY STAR model (Increment 3, described below), measures that were expected to have a negative or zero capital cost were added first, and then measures were added that were deemed to have the highest benefit-to-cost ratio. In this example, the unvented 
attic measure was included as Increment 7 . Increment 11 represented the prototype house, but Increment 12 was added because we expected production houses to be built with SEER 10 air conditioners. The following section describes the changes made for each increment.

Table 11. Summary of Modeling Results for Pulte, Tucson

\begin{tabular}{|c|c|c|c|c|c|c|c|c|c|}
\hline \multirow[b]{2}{*}{ Increment } & \multirow{2}{*}{$\begin{array}{c}\mathrm{Htg} / \mathrm{Clg} \\
\mathrm{kWh}\end{array}$} & \multirow{2}{*}{$\begin{array}{l}\text { Heating } \\
\text { therms }\end{array}$} & \multirow{2}{*}{\multicolumn{2}{|c|}{$\begin{array}{c}\mathrm{Htg} / \mathrm{Clg} \\
\text { Cost }\end{array}$}} & \multirow{2}{*}{$\begin{array}{l}\text { Measure } \\
\text { value }(\$ / y r)\end{array}$} & \multirow{2}{*}{\multicolumn{2}{|c|}{$\begin{array}{l}\text { Package } \\
\text { savings \$/yr }\end{array}$}} & \multicolumn{2}{|c|}{$\begin{array}{c}\text { Cost } \\
\text { Savings over }\end{array}$} \\
\hline & & & & & & & & Std & E-Star \\
\hline 0: Builder Stand. Practice (BSP) & 4977 & 92 & $\$$ & 593 & & & & & \\
\hline 1: BSP + incr. Insulation & 4613 & 79 & $\$$ & 545 & 48.2 & $\$$ & 48 & & \\
\hline 2: BSP + vinyl frames & 4321 & 66 & $\$$ & 505 & 40.7 & $\$$ & 89 & & \\
\hline $\begin{array}{l}\text { 3: BSP + } 12 \text { SEER } \\
\text { (Energy Star base case) }\end{array}$ & 3670 & 66 & $\$$ & 436 & 68.4 & $\$$ & 157 & $26 \%$ & \\
\hline 4: E-Star +4 to 3 tons & 3745 & 66 & $\$$ & 444 & $(7.9)$ & $\$$ & 149 & & \\
\hline 5: E-Star + 24" o.c. & 3733 & 64 & $\$$ & 441 & 2.9 & $\$$ & 152 & & \\
\hline 6: E-Star +PPG1000 & 2566 & 54 & $\$$ & 311 & $\$ 130.2$ & $\$$ & 282 & $48 \%$ & \\
\hline 7: E-Star + Unv Roof & 2586 & 71 & $\$$ & 326 & $\$ \quad(15.2)$ & $\$$ & 267 & & \\
\hline 8: E-Star + AFUE 93 & 2586 & 62 & $\$$ & 319 & 6.9 & $\$$ & 274 & & \\
\hline 9: E-Star +3 to 2 ton & 2628 & 61 & $\$$ & 323 & $(3.6)$ & $\$$ & 271 & & \\
\hline 10: E-Star + DHW EF62 & 2628 & 61 & $\$$ & 323 & $\$$ & $\$$ & 271 & $46 \%$ & $26 \%$ \\
\hline 11: E-Star + vent $(60 \mathrm{cfm})$ & 3209 & 94 & $\$$ & 409 & $(86.4)$ & $\$$ & 184 & $31 \%$ & $6 \%$ \\
\hline 12: E-Star + SEER 10 (prototype) & 3695 & 94 & $\$$ & 460 & $(51.0)$ & $\$$ & 133 & $22 \%$ & $-6 \%$ \\
\hline
\end{tabular}

\section{- Builder Standard Practice (Increment 0)}

Builder standard practice was the starting point for the analysis and was based on the geometry of the prototype house designed and built by Pulte Homes in Tucson on Lot 580 of the Retreat at the Bluffs development. The energy features of this house were adjusted to match builder standard practice, as described in the BSC memo of July 27, 1999.

Features: Ceiling

Walls

Foundation

Windows

Infiltration

Duct leakage

Heating system

Cooling system

DHW
R-30 flat attic vented

R-13 16-in. oc + R-4 EPS exterior

R-13 16-in. oc to garage

Slab, uninsulated

Metal frame, double-glazed

$\mathrm{U}=0.87, \mathrm{SHGC}=0.73$

As measured

$7 \%$ total, $5.4 \%$ lost to outside

$80 \%$ AFUE furnace in vented attic

10 SEER air conditioner, 4-ton

$0.56 \mathrm{EF}$ 


\section{- Increased wall insulation (Increment 1)}

Wall-cavity insulation was increased to a nominal R-19, based on 2 x 6 wall construction. This applied to all exterior walls as well as the wall between the house and garage.

- Vinyl-frame window upgrade (Increment 2)

Window frames were upgraded from metal frames (aluminum, no thermal break) to vinyl frames. The frame conductance in the DOE-2.2 model changed from $3.04 \mathrm{Btu} / \mathrm{hr} \bullet \mathrm{ft}^{2} \cdot{ }^{\circ} \mathrm{F}$

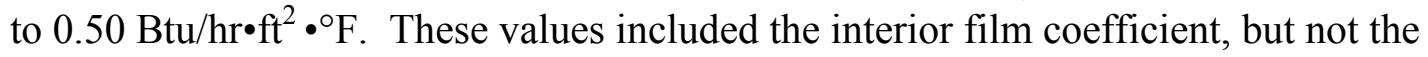
exterior film coefficient, and were based on two-dimensional heat loss.

- Air-conditioner upgrade to SEER 12 (Increment 3)

The air conditioner SEER was increased from 10 to 12. For DOE-2.2, the SEER was converted to a design energy-input-ratio (EIR) using the California Title-24 recommended method, which separated out the assumed fan power and the compressor and condenser power. This increment brought the builder standard practice case up to the Energy Star energy efficiency level.

\section{- Air conditioner downsizing to 3 tons (Increment 4)}

The air conditioner capacity was decreased to 3 tons, from the builder standard practice capacity of 4 tons. The total supply flow rate was reduced as well, remaining at $350 \mathrm{cfm}$ per ton. Supply fan electric use changed from 0.55 watts per $\mathrm{cfm}$ to 0.60 watts per $\mathrm{cfm}$ based on field measurements of similar systems. This was the first added measure to the Energy Star configuration (Increment 3 ) because it had a negative associated cost and small energy cost benefit.

- Wall framing-factor reduction (Increment 5)

Exterior walls were changed to 24 -in. oc from 16-in. oc, increasing the effective R-value of the wall construction by approximately $1 \mathrm{Btu} / \mathrm{hr}^{\circ} \mathrm{ft}^{2} \cdot{ }^{\circ} \mathrm{F}$. As with the previous increment, this measure was reported to have a negative first-cost and a small energy cost benefit.

\section{- High-performance glazing (Increment 6)}

All windows were replaced with Sungate1000 high-performance windows, which have low-e coatings and low solar gain factors. Whole window U-value was $0.35 \mathrm{Btu} / \mathrm{hr} \cdot \mathrm{ft}^{2}$ ${ }^{\circ} \mathrm{F}$, compared with 0.87 for the clear double-glass window it replaced. The glass solar heat-gain coefficient was reduced to 0.37 , from 0.73 . This measure had a significant energy impact and a very quick payback period.

\section{- Unvented attic (Increment 7)}

For the unvented attic design, the attic insulation was moved from the ceiling plane or attic floor to the roof plane. The roof type was changed to a sloped roof with a tile surface. The attic was unintentionally conditioned by duct leakage, conductive losses, and air transfer between the attic and house (Table 12). 
Table 12. Increment 7: Change from Vented to Unvented Attic

\begin{tabular}{llll}
\hline & Vented Attic (base) & Vented Attic (E-Star) & Unvented Attic \\
\hline Roof Type/Surface & Flat/Membrane & Flat/Membrane & Sloped/Tile \\
Insulation & Ceiling: R-30 & Ceiling: R-30 & Roof: R-21, Walls: R-19 \\
Infiltration & $1.5 \mathrm{ACH}$ & $1.5 \mathrm{ACH}$ & $0.15 \mathrm{ACH}$ \\
Duct supply leakage & $7 \%$ of supply cfm & $2 \%$ of supply cfm & $2 \%$ of supply cfm \\
Leakage to outside & $80 \%(78 \mathrm{cfm})$ & $80 \%(25 \mathrm{cfm})$ & $25 \%(8 \mathrm{cfm})$ \\
Design duct delta-T & $1.5^{\circ} \mathrm{F}$ & $1.5^{\circ} \mathrm{F}$ & $1.5^{\circ} \mathrm{F}$ \\
\hline
\end{tabular}

The tracer gas test showed the air-exchange rate associated with fan operation for the unvented attic to be very small, on the order of $8 \mathrm{cfm} \pm 2 \mathrm{cfm}$. The base-case test house with a vented attic also showed very low air exchange associated with fan operation, probably the result of poor ventilation associated with the flat roof design. Significantly higher air loss to the attic was assumed for the builder standard practice case. With a total supply flow rate of $1,400 \mathrm{cfm}$, builder standard practice was assumed to have about $98 \mathrm{cfm}$ airflow loss to the attic ( $7 \%$ of total). For the vented attics, it was assumed that $80 \%$ of the supply airflow to the attic was exhausted to the outside and thus made up from outside air. The remaining $20 \%$ was made up through return air leaks from the attic. For the unvented attic, it was assumed that $25 \%$ of the duct leakage was directly to the outside, while the other $75 \%$ mixed with the attic air. These estimates of duct leakage lost to the outside were calculated as part of the calibration of the model to the field test data.

- Heating system AFUE improvement (Increment 8)

The 80.0 AFUE furnace was replaced with a more efficient 92.6 AFUE furnace. The unvented attic measure required using this more-efficient, closed-combustion, condensing furnace because the attic was now essentially part of the conditioned space.

- Air conditioner downsizing to 2 tons (Increment 9)

The air conditioner capacity was decreased to 2 tons, from the previous capacity of 3 tons. The total supply flow rate was reduced as well, remaining at $350 \mathrm{cfm}$ per ton. Supply fan electric use changed from 0.60 watts per cfm to 0.65 watts per $\mathrm{cfm}$ based on field measurements of similar systems. The smaller cooling capacity was only an option after the cooling load had been reduced by the combination of better glazing and the unvented attic.

- DHW heater improvement (Increment 10)

The standard gas DHW heater with an Energy Factor (EF) of 0.56 was replaced with a heater with an EF of 0.62 . 
- Continuous ventilation (Increment 11)

An exhaust fan was added to provide a continuous $60 \mathrm{cfm}$ of outside air to the house. The fan was assumed to use 40 watts.

- Air conditioner SEER 10 (Increment 12)

The air conditioner SEER was decreased from 12 to 10 . This cost trade-off measure was added last so that the previous measure would indicate the performance of the Building America home with a SEER of 12.

A series of sensitivity runs were made with the Tucson model to ensure that building components were being modeled correctly and to gauge the importance of certain assumptions. Several of the more interesting sensitivity studies are provided in the appendix.

\section{Key Findings}

Several conclusions were drawn from the testing and analysis performed for the Pulte Homes Tucson project:

- The unvented attic yielded a much milder environment for the ducts during the test period, with an attic temperature less than $4^{\circ} \mathrm{C}\left(7.2^{\circ} \mathrm{F}\right)$ higher than the inside temperature. By contrast, the temperature of the vented attic with a flat roof greatly exceeded the outside temperature during sunny afternoons, reaching temperatures more than $25^{\circ} \mathrm{C}$ $\left(45^{\circ} \mathrm{F}\right)$ hotter than the interior of the house.

- Duct leakage, insulating-value, air infiltration at the roof plane, and solar heat absorption by the roof are important factors when calculating the potential energy savings or penalty of an unvented attic compared to a vented attic. (See the appendix.) 


\section{Extension to Other Hot-Dry/Mixed-Dry Climates}

The base-case and prototype models for Watt Homes in Las Vegas were run with a range of duct leakage levels for two other climate zones, Phoenix (hot-dry) and Sacramento (mixed-dry). The simulations assumed that most of the duct leakage was on the supply side of the air distribution system, and the cooling capacity was set to a constant $500 \mathrm{ft}^{2}$ per ton in each case. These assumptions were based on field-testing of similar Building America projects. For each location, a graph illustrating the sensitivity of cooling energy to duct leakage is presented. These results are shown in Figures 31 and 32.

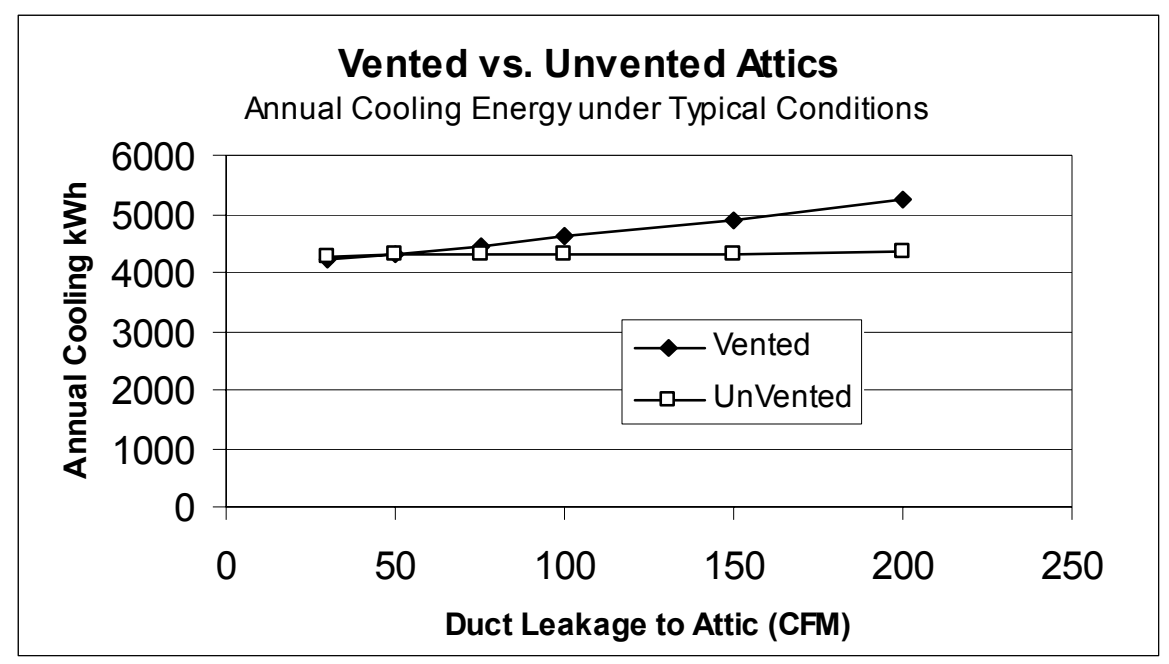

Figure 31. Comparison of cooling energy for vented and unvented attics in Phoenix, Arizona

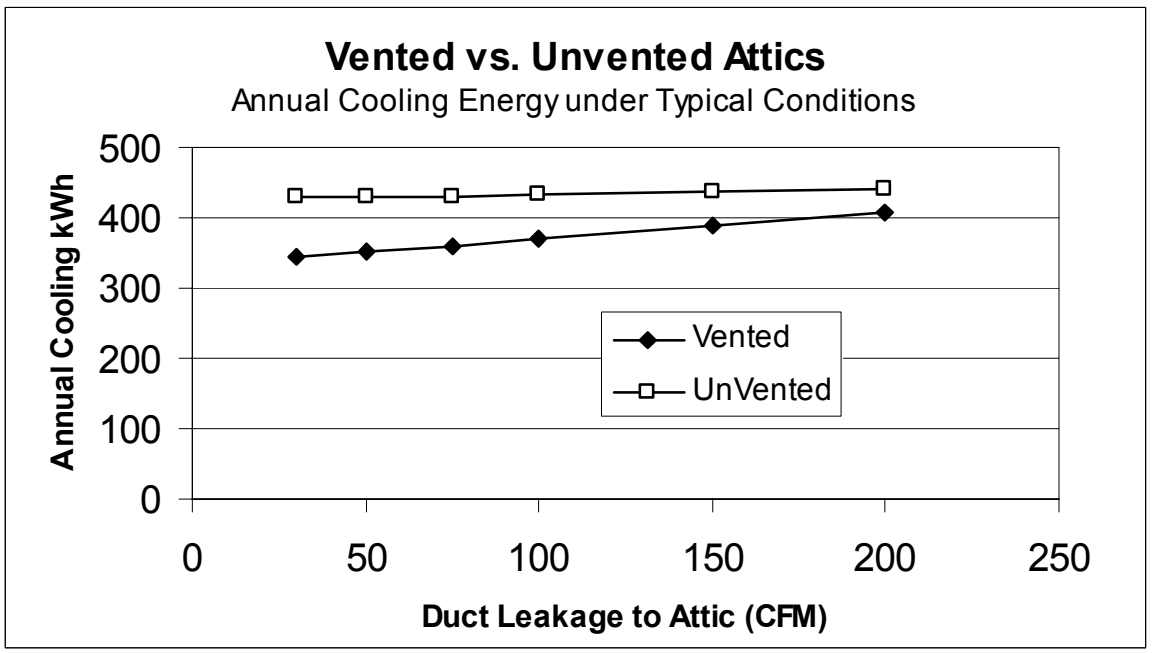

Figure 32. Comparison of cooling energy cost for vented and unvented attics in Sacramento, California 
Climate is a very important factor when calculating how an unvented attic affects cooling energy usage. When the ducts are leaky, there seems to be a clear benefit associated with the unvented attic in the case of Phoenix, which has a very large number of cooling degree days during the summer. However, the same house in Sacramento seems to have a cooling energy penalty compared to a house with a vented attic. Heating energy also becomes an important consideration in milder climates like Sacramento, but the model used for this study was not designed to accurately predict heating loads.

Furthermore, it is clear that the trade-off between vented and unvented attics is strongly influenced by the amount of duct leakage regardless of climate. As one would expect, the performance of a vented attic is more sensitive to the amount of duct leakage because the attic temperature is more variable and a greater fraction of the leakage is lost to the outside.

\section{Conclusions}

The series of field tests and DOE-2.2 simulations conducted by NREL on unvented attics leads to several important conclusions:

- Properly constructed unvented attics can save energy in cooling-dominated climates under the right circumstances

- Unvented attics in hot-dry climates have a small effect on cooling energy usage when duct leakage is small

- When supply duct leakage is greater than $5 \%$ of total flow rate, unvented attics begin to produce meaningful energy savings for heating and cooling. For example, cooling energy savings is predicted to be about $8 \%$ when duct leakage is $10 \%$, which is fairly typical for Building America base-case houses

- Weather conditions, duct leakage, roof R-value, attic air-exchange rate, and effective roof absorptivity $^{*}$ all play important roles in determining whether or not energy savings are achieved with an unvented attic

- The cost-effectiveness of alternative measures, such as improving the airtightness of ducts, should be carefully considered when deciding whether or not to use an unvented attic.

\footnotetext{
${ }^{*}$ Effective roof absorptivity includes the effects of roofing material absorptivity, self-ventilation, and thermal mass.
} 


\section{Appendix: Sensitivity Analysis of the Pulte, Tucson, Unvented Attic Prototype}

The following sensitivity studies were based on the prototype and base-case houses constructed by Pulte Homes in Tucson, as described in Case 2 of this report. Table 13 contains a list of the nominal parameters for the two houses. The comparison between vented and unvented attics is not a very meaningful one in the following series of graphs, because the base case (or "vented attic" case) includes an atypical attic design with a flat roof, higher R-value, greater duct leakage, and a relatively small amount of ventilation. However, the results do shed light on which attic design parameters have the greatest effect on energy use and which should receive the greatest attention when considering the cost-effectiveness of an unvented attic in a hot-dry climate.

As shown in Figures A-1 to A-3, duct leakage is a very important parameter that influences the energy savings (or loss) that can be expected from an unvented attic. The point has already been made several times in this report and is simply reinforced by the analysis presented here.

Another observation is that a roof should be very airtight to take full advantage of an unvented attic, as shown in Figures A-4 to A-6. Leaks at the roof plane cause the attic space to track the outside temperature more than the inside, resulting in greater energy losses from the ducts. The overall air leakage of the house is also increased, placing additional loads on the heating and cooling systems. The analysis indicates that attic air infiltration has a somewhat larger effect on the heating load than the cooling load.

Similarly, it is important to maintain a relatively high R-value at the roof plane if meaningful energy savings are to be achieved using an unvented attic, as shown in Figures A-7 to A-9. Insulation is usually more difficult to install in a uniform manner at the roof plane because the forces of gravity work against the installer. For the Tucson project, the analysis indicates that additional energy savings would have resulted if the roof of the unvented attic had the same Rvalue as the floor of the vented attic (R-30).

Finally, the solar absorptivity of the roofing material has an interesting effect on heating and cooling energy for a house with an unvented attic, as shown in Figures A-10 to A-12. The unvented attic is clearly more sensitive to the absorptivity of the roof, but the benefits of reflective materials in the summer are largely offset by additional heating loads in the winter. The more important benefit of reflective roofing materials in the context of an unvented attic is the reduction in roof sheathing temperature during hot, sunny days. This is a durability issue being further investigated by BSC and FSEC as part of their Building America research efforts.

Table A-1. Nominal Values of Parameters Used in the Sensitivity Analysis

\begin{tabular}{|l|c|c|}
\hline Item & Vented Attic & Unvented Attic \\
\hline Duct Leakage & $98 \mathrm{cfm}$ & $32 \mathrm{cfm}$ \\
\hline Attic Infiltration & $1.5 \mathrm{ACH}$ & $0.15 \mathrm{ACH}$ \\
\hline Roof /Ceiling R-Value & $\mathrm{R}-30$ & $\mathrm{R}-22$ \\
\hline Roof Absorptivity & 0.5 & 0.7 \\
\hline
\end{tabular}




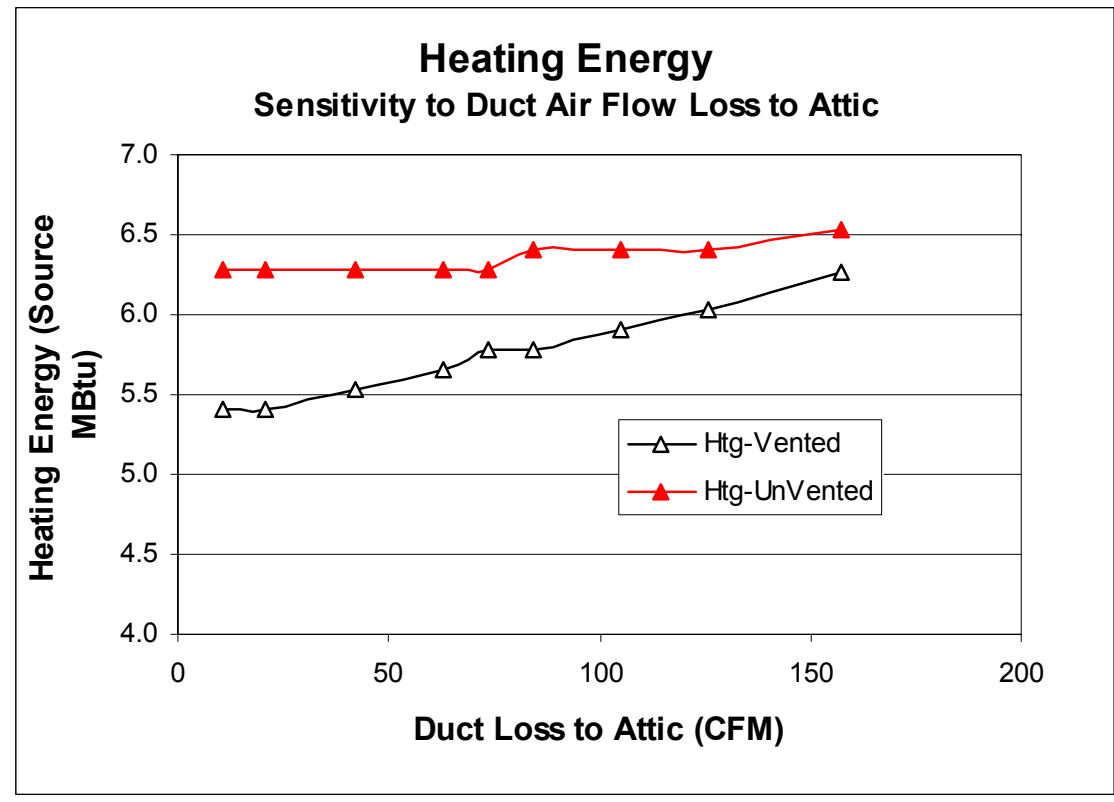

Figure A-1. Comparison of heating energy for vented and unvented attics, sensitivity to duct leakage

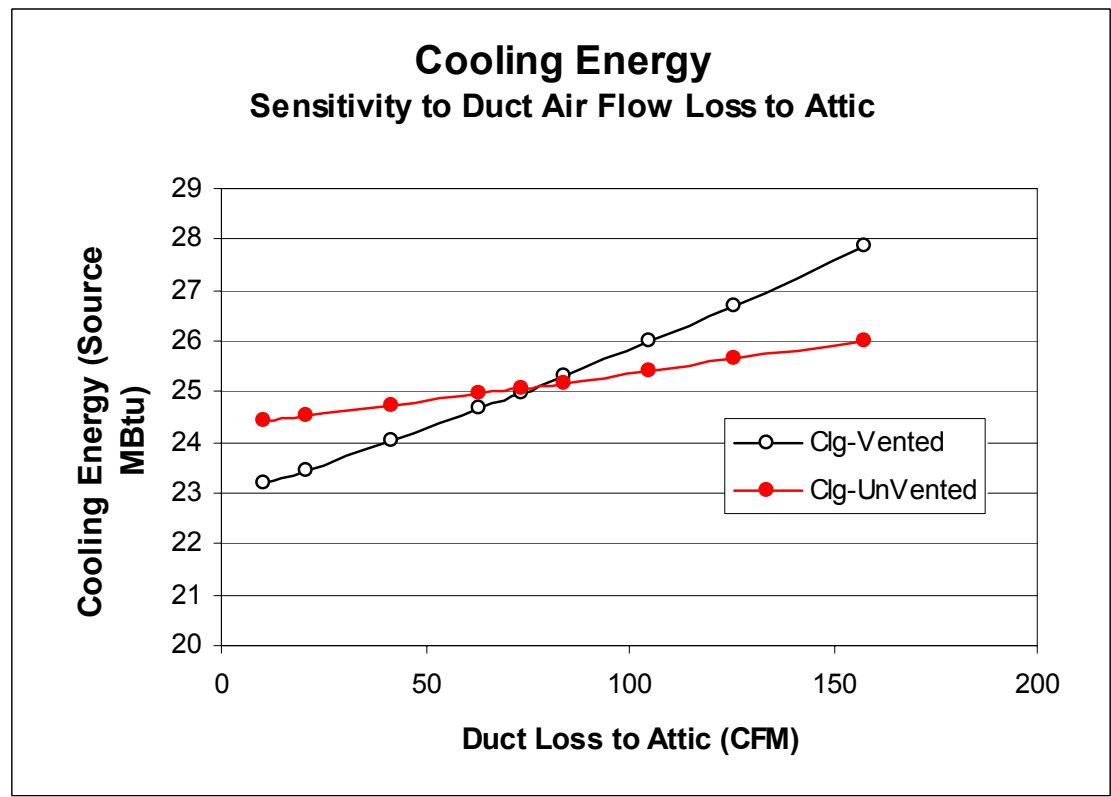

Figure A-2. Comparison of cooling energy for vented and unvented attics, sensitivity to duct leakage 


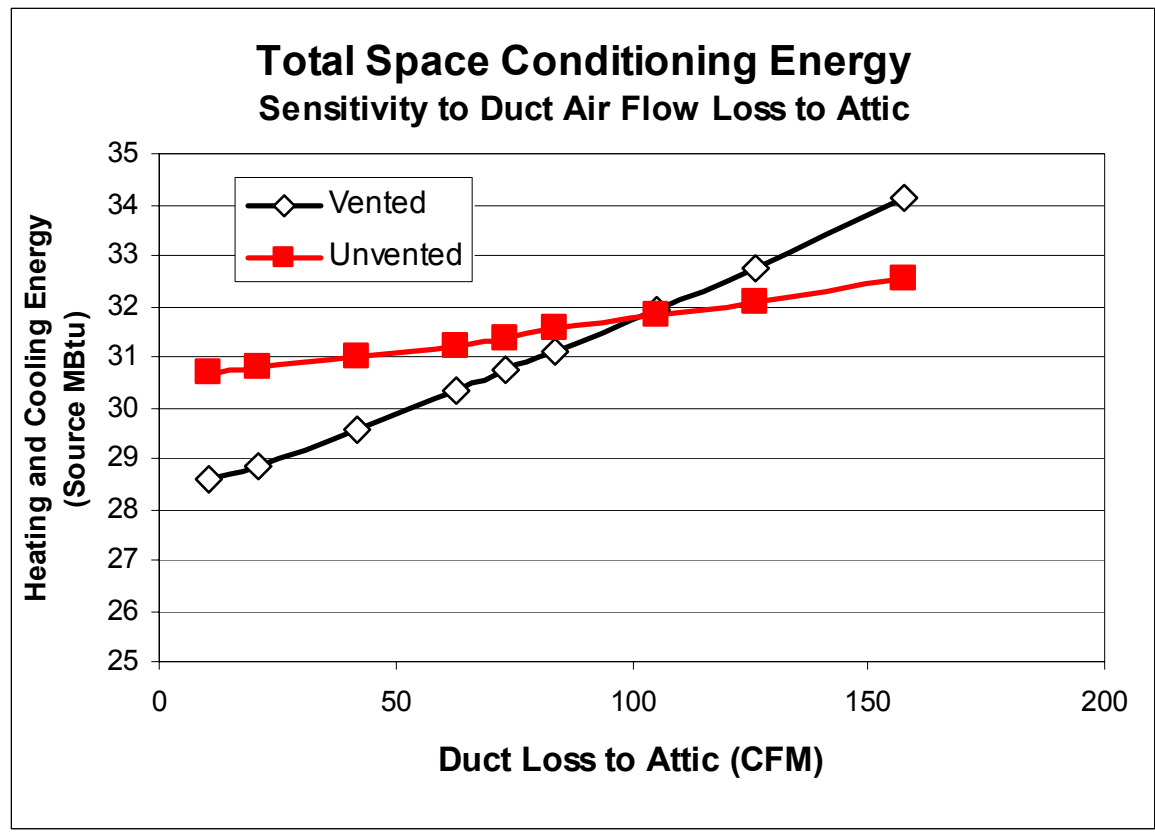

Figure A-3. Comparison of total space-conditioning energy for vented and unvented attics, sensitivity to duct leakage

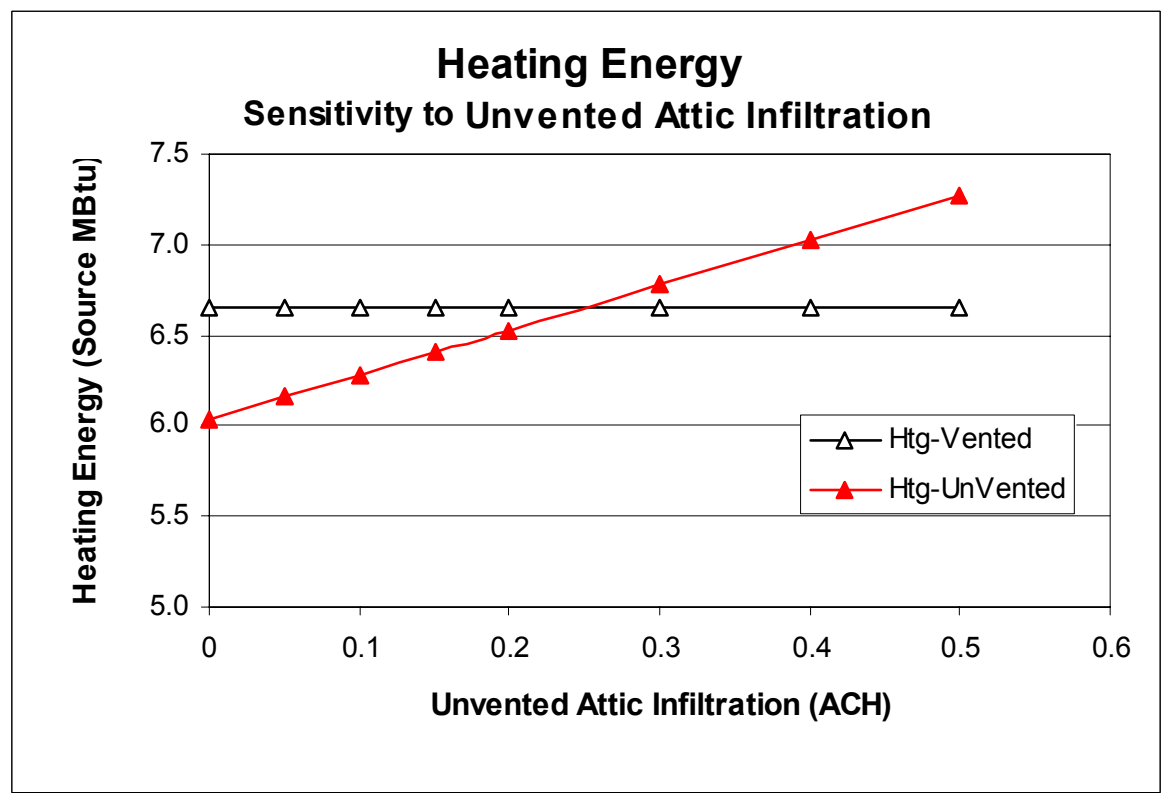

Figure A-4. Comparison of heating energy for vented and unvented attics, sensitivity to unvented attic air infiltration (Vented attic infiltration is held constant at 1.5 ACH) 


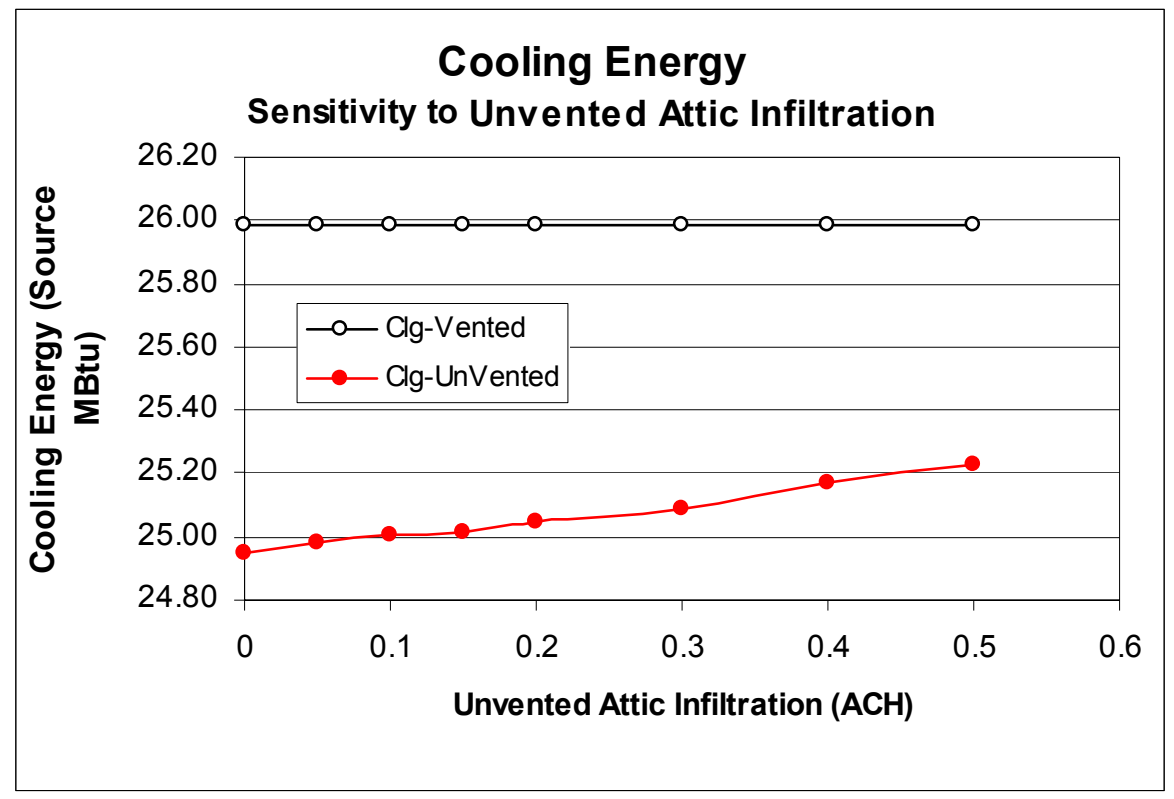

Figure A-5. Comparison of cooling energy for vented and unvented attics, sensitivity to unvented attic air infiltration (Vented attic infiltration is held constant at $1.5 \mathrm{ACH}$ )

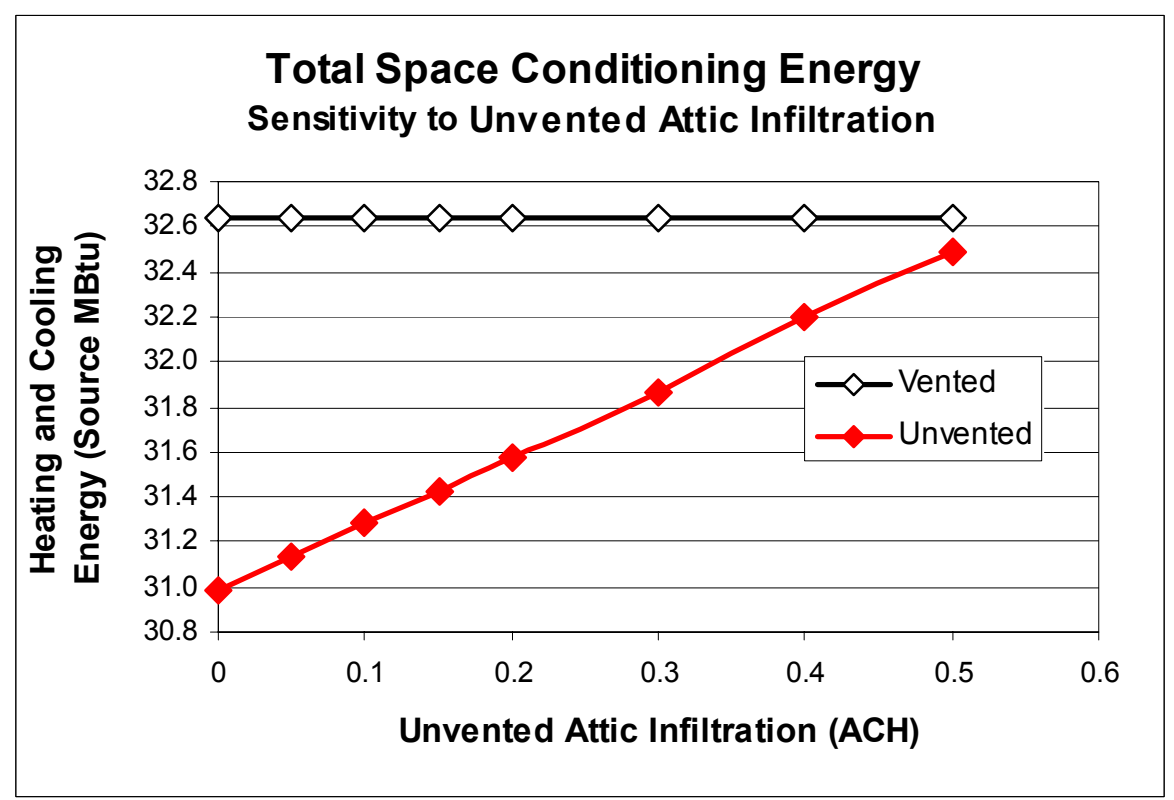

Figure A-6. Comparison of total space-conditioning energy for vented and unvented attics, sensitivity to unvented attic air infiltration (Vented attic infiltration is held constant at $1.5 \mathrm{ACH}$ ) 


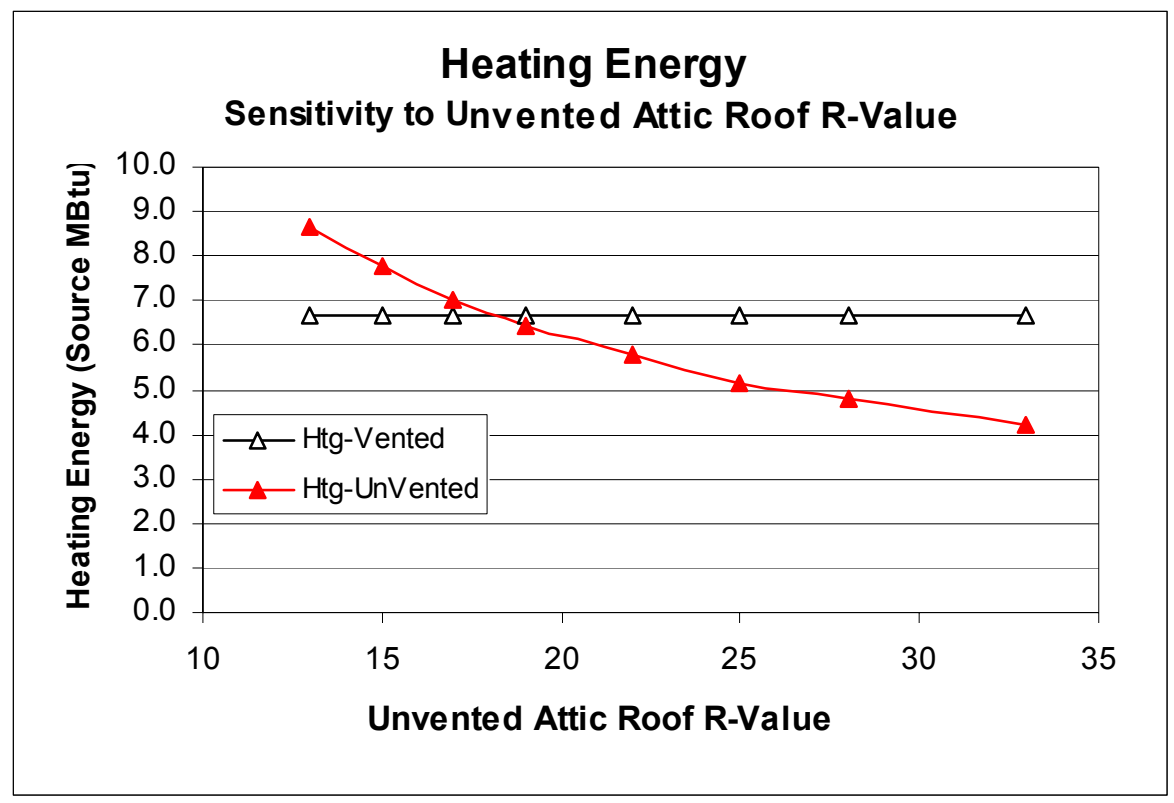

Figure A-7. Comparison of heating energy for vented and unvented attics, sensitivity to unvented attic roof $R$-value (Vented attic R-value is held constant at R-30)

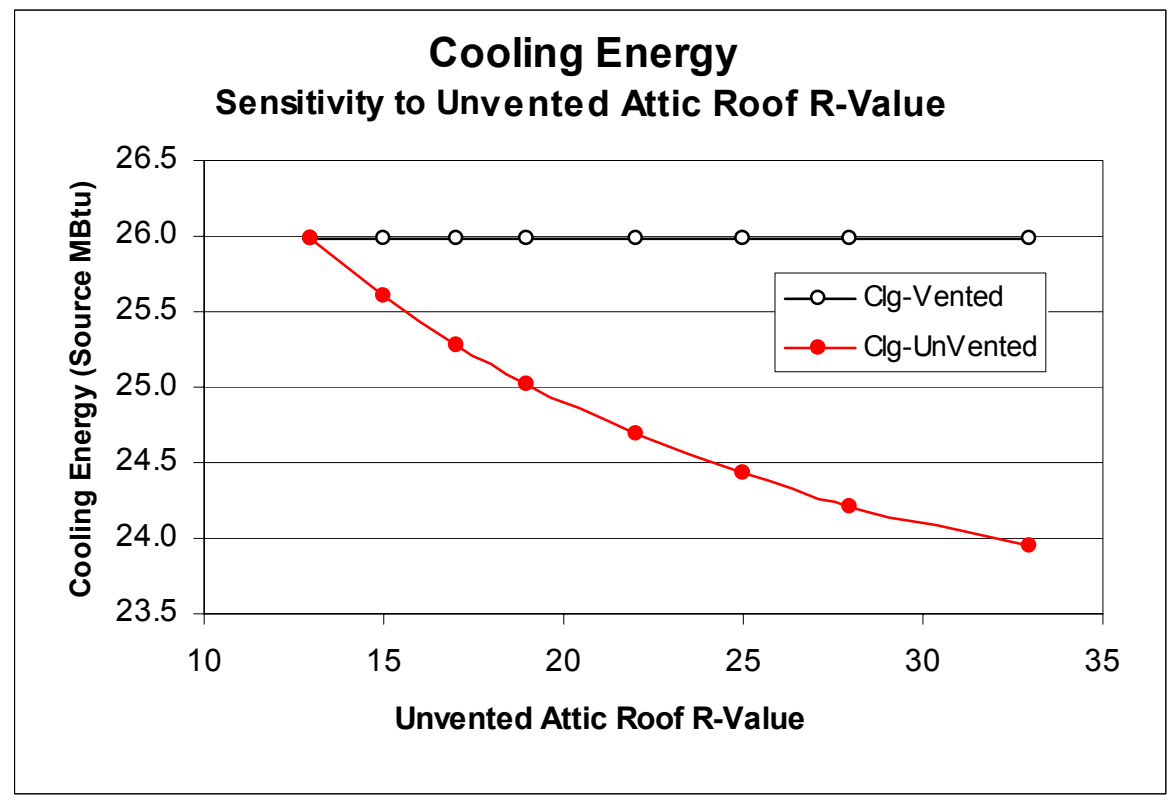

Figure A-8. Comparison of cooling energy for vented and unvented attics, sensitivity to unvented attic roof $R$-value (Vented attic R-value is held constant at R-30) 


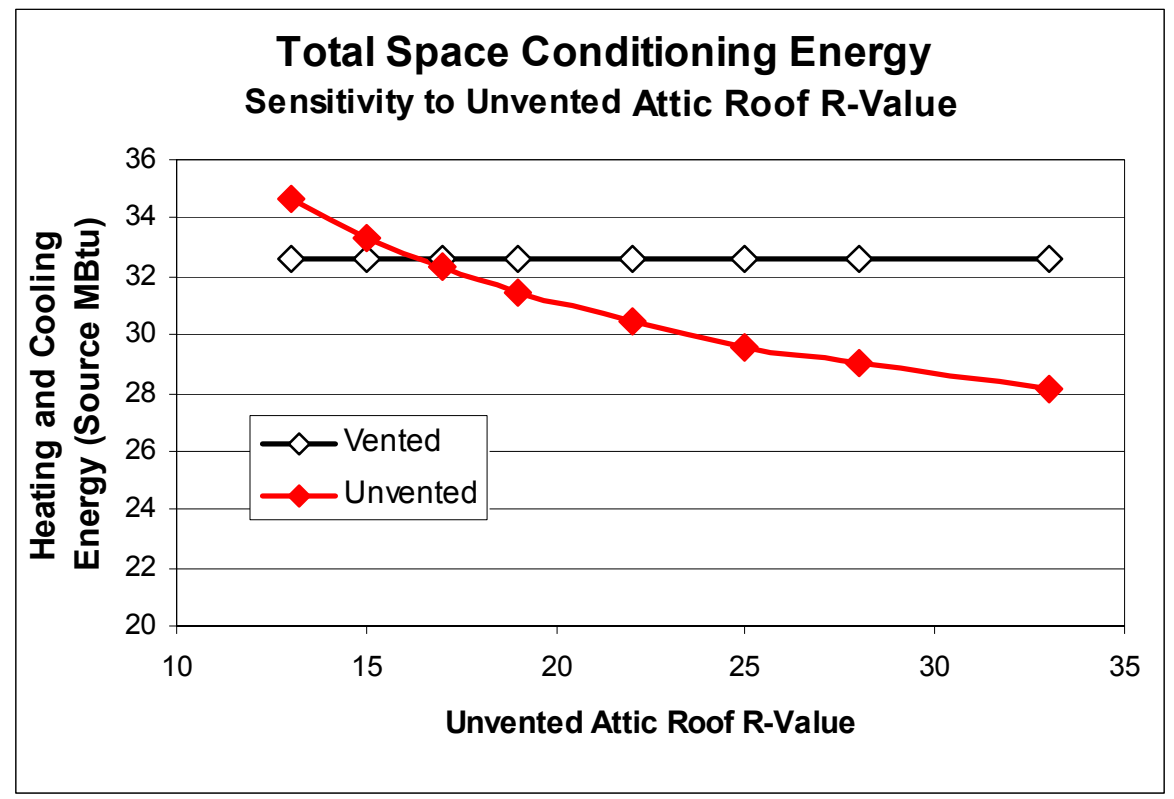

Figure A-9. Comparison of total space-conditioning energy for vented and unvented attics, sensitivity to unvented attic roof $R$-value (Vented attic R-value is held constant at R-30)

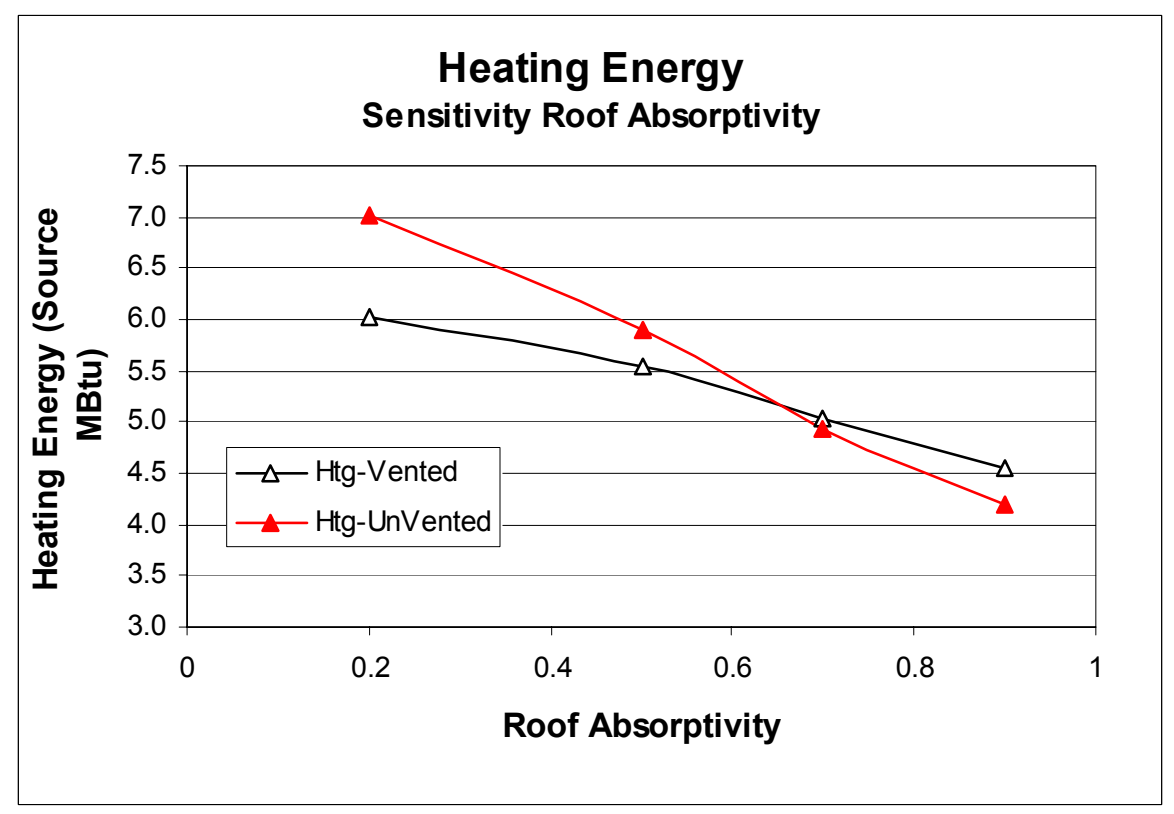

Figure A-10. Comparison of heating energy for vented and unvented attics, sensitivity to roof absorptivity 


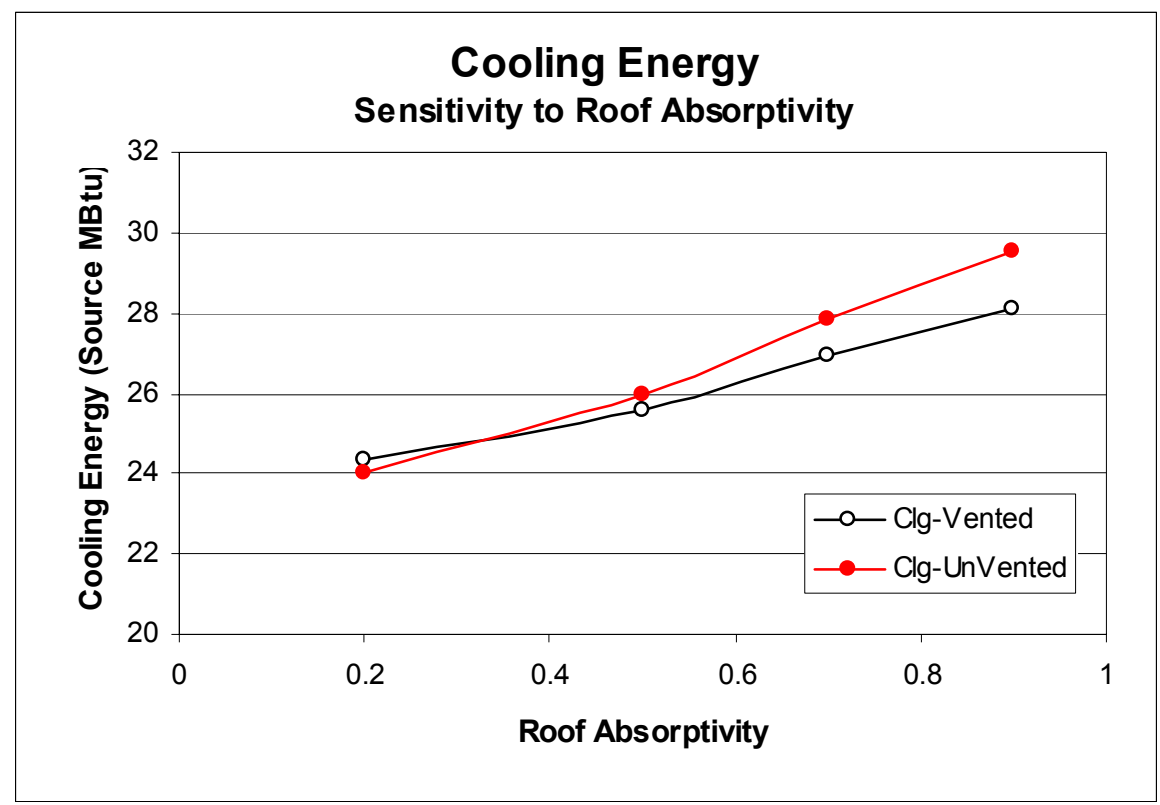

Figure A-11. Comparison of cooling energy for vented and unvented attics, sensitivity to roof absorptivity

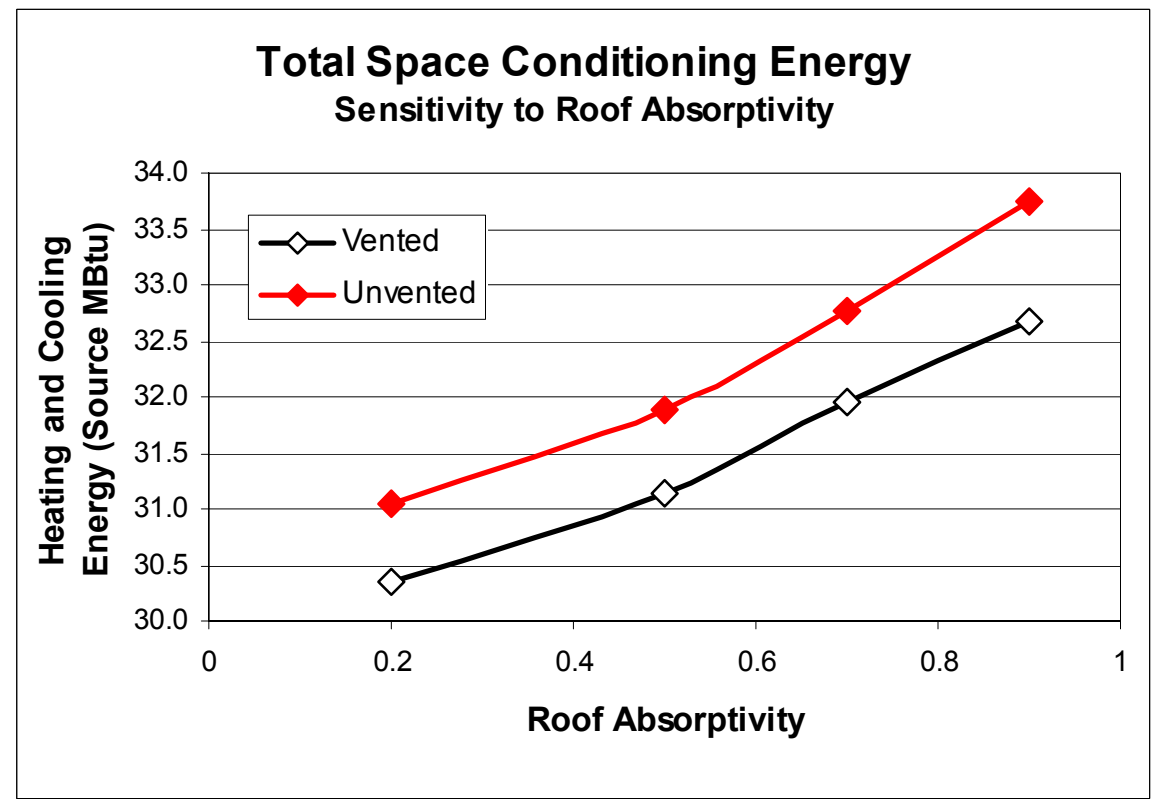

Figure A-12. Comparison of space-conditioning energy for vented and unvented attics, sensitivity to roof absorptivity 


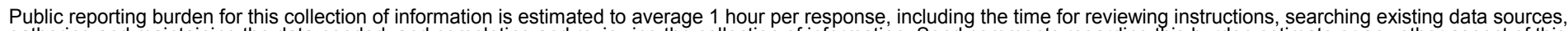

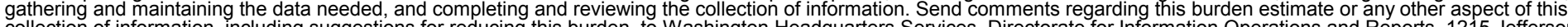
Davis Highway, Suite 1204, Arlington, VA 22202-4302, and to the Office of Management and Budget, Paperwork Reduction Project (0704-0188), Washington, DC 20503.
1. AGENCY USE ONLY (Leave blank)
2. REPORT DATE
April 2002
3. REPORT TYPE AND DATES COVERED
Technical Report

4. TITLE AND SUBTITLE

Thermal Performance of Unvented Attics in Hot-Dry Climates

5. FUNDING NUMBERS

6. $\operatorname{AUTHOR}(\mathrm{S})$

R. Hendron, R. Anderson, P. Reeves, E. Hancock

BET2.8004

7. PERFORMING ORGANIZATION NAME(S) AND ADDRESS(ES)

Partnership for Resource Conservation

8. PERFORMING ORGANIZATION

Mountain Energy Partnership REPORT NUMBER

9. SPONSORING/MONITORING AGENCY NAME(S) AND ADDRESS(ES)

National Renewable Energy Laboratory

1617 Cole Blvd.

Golden, CO 80401-3393

10. SPONSORING/MONITORING AGENCY REPORT NUMBER

NREL/TP-550-30839

11. SUPPLEMENTARY NOTES

NREL Technical Monitor: Bob Hendron

12a. DISTRIBUTION/AVAILABILITY STATEMENT

National Technical Information Service

12b. DISTRIBUTION CODE

U.S. Department of Commerce

5285 Port Royal Road

Springfield, VA 22161

13. ABSTRACT (Maximum 200 words)

As unvented attics become a more common design feature implemented by Building America partners in hot-dry climates of the United States, more attention has been focused on how this approach affects heating and cooling energy consumption. The National Renewable Energy Laboratory (NREL) has conducted field testing and hourly building simulations for several Building America projects to evaluate energy use in vented and unvented attics in hot-dry climates. In summer, testing of the Las Vegas protoype house demonstrated that the thermal performance of an unvented attic is highly dependent on duct leakage.

14. SUBJECT TERMS unvented attic, vented attic, conditioned attic, sealed attic, energy efficiency, duct leakage, duct losses

15. NUMBER OF PAGES

7. SECURITY CLASSIFICATION OF REPORT Unclassified

18. SECURITY CLASSIFICATION OF THIS PAGE Unclassified
19. SECURITY CLASSIFICATION OF ABSTRACT Unclassified
16. PRICE CODE

20. LIMITATION OF ABSTRACT

UL 